2008

\title{
Physiological and Molecular Characterization of Genetic Competence in Streptococcus sanguinis
}

Alejandro Rodriguez

Virginia Commonwealth University

Follow this and additional works at: https://scholarscompass.vcu.edu/etd

Part of the Medicine and Health Sciences Commons

() The Author

\section{Downloaded from}

https://scholarscompass.vcu.edu/etd/1570

This Thesis is brought to you for free and open access by the Graduate School at VCU Scholars Compass. It has been accepted for inclusion in Theses and Dissertations by an authorized administrator of VCU Scholars Compass.

For more information, please contact libcompass@vcu.edu. 
(C) Alejandro Miguel Rodriguez, 2008

All Rights Reserved 
PHYSIOLOGICAL AND MOLECULAR CHARACTERIZATION OF GENETIC COMPETENCE IN STREPTOCOCCUS SANGUINIS

A Thesis submitted in partial fulfillment of the requirements for the degree of Master of Science at Virginia Commonwealth University.

by

ALEJANDRO MIGUEL RODRIGUEZ

B.S. Biology, University of Miami, 2005

Director: Todd O. Kitten, Ph.D.

Associate Professor, School of Dentistry

Virginia Commonwealth University

Richmond, Virginia

August 2008 


\section{Acknowledgement}

I would like to thank God first and foremost for blessing me with all the people in my life without who I would not be where I am today. I would like to thank my wife, Larissa, for her unending love and understanding over the last three years, for putting up with the all-nighters, and for always motivating me to push through the rough times and achieve my dreams. I would also like to thank my parents for their love and support, my mother's excitement over any success I had in the lab, no matter how small it may have been, and for my father's incessant badgering to "find the cure." Lastly, I would like to express my appreciation for my in-laws for their generous hospitality, for making my transition from Miami to Richmond a relatively painless experience, and of course my mother-in-law's famous chili.

I would like to thank all my colleagues in the lab: Dr. Sankar Das, my scapegoat for whenever my experiments didn't work; Lauren Turner, who helped me tremendously in the beginning stages of my project, and was always willing to lend a hand whenever I needed it; Nicai Zollar, who always helped me find items in the lab and shares my love of 80's music and anime; Jill Callahan, for her help in the RNA isolation protocol and always keeping me updated on the latest A-Rod gossip; Da'Shekia Mitchell who helped me get a grasp on the transformation protocols early on, and for her advice throughout the purchasing of my first home; and lastly Brian Mahoney, who was finally able to organize the lab to have lunch at the same time. Thank you all for your help and expertise, as well as all the laughs and great times over the last two years.

Lastly, I would like to express my most sincere gratitude to my mentor Dr. Todd Kitten who took me under his wing and helped mold me into the scientist I am today. I would like to thank him for all the guidance throughout this project as well as the thoughtprovoking questions that always kept me on my toes. Lastly, I would like to thank him for all the wonderful activities he has organized for our lab, and of course all the birthday lunches over the years. 


\section{Table of Contents}

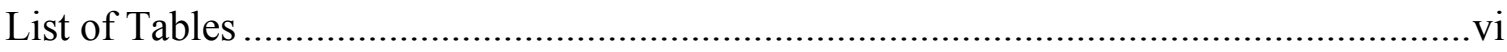

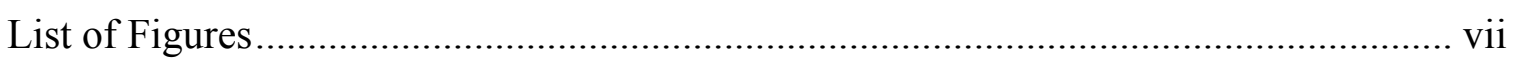

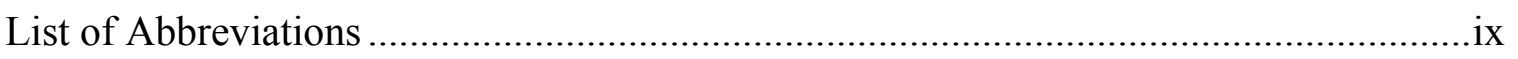

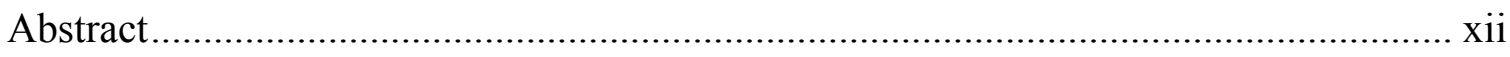

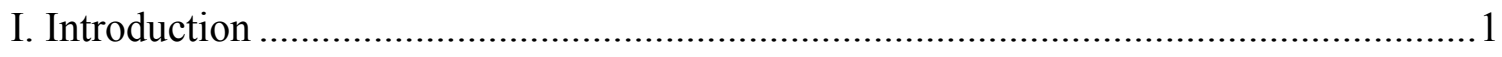

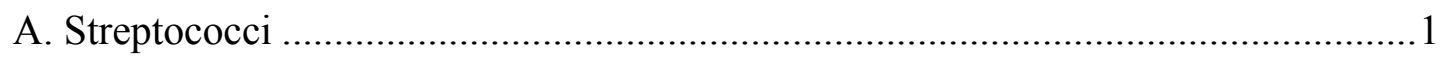

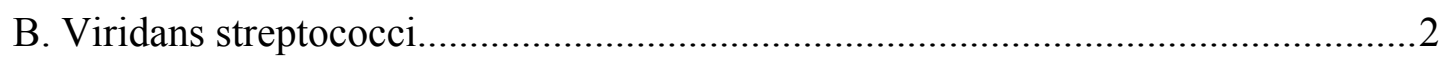

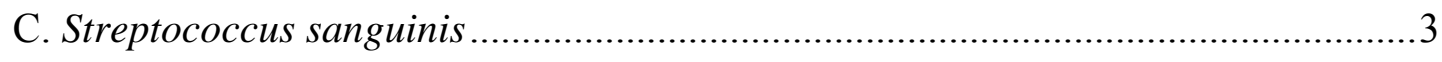

D. Infective endocarditis..............................................................................

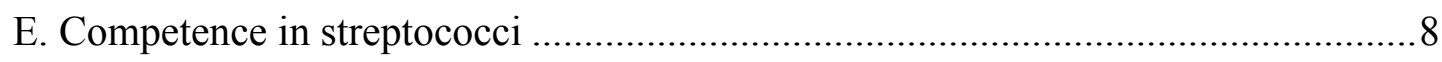

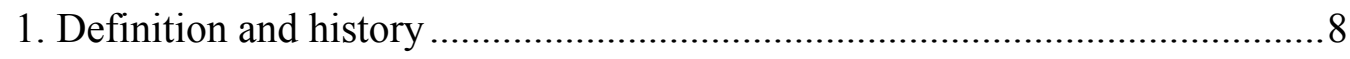

2. Genes associated with competence...................................................

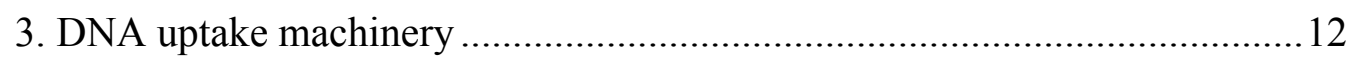

4. Difference in competence regulation in S. mutans with respect to

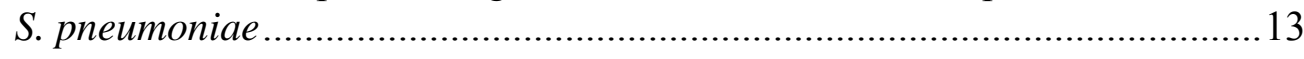

5. Putative com genes in S. sanguinis .................................................. 17

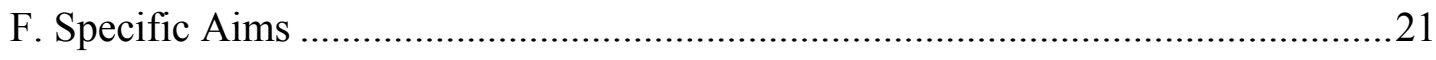

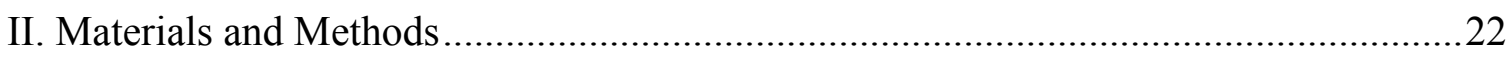

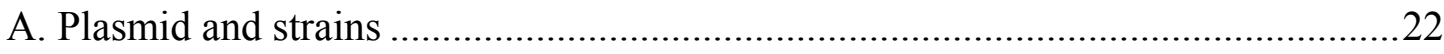

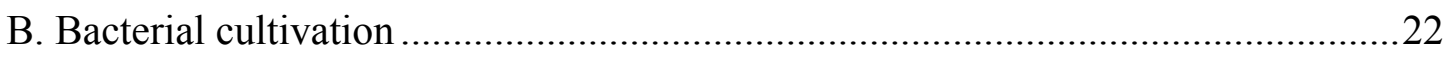




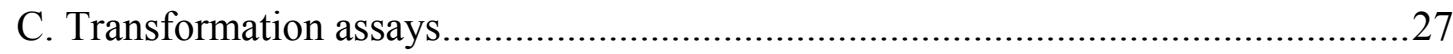

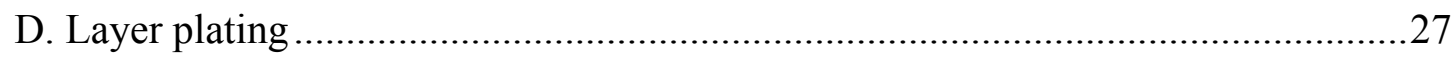

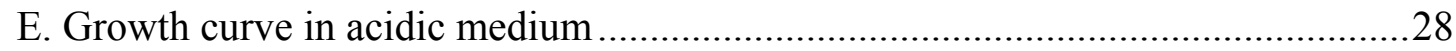

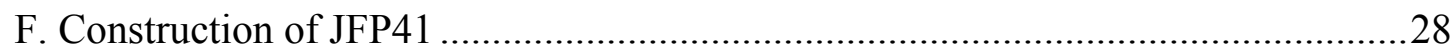

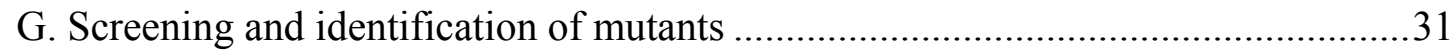

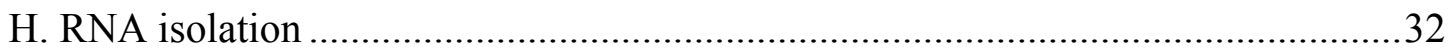

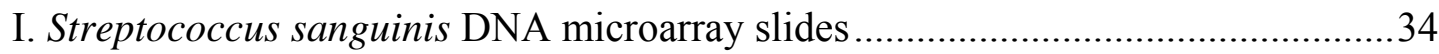

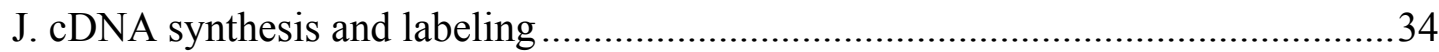

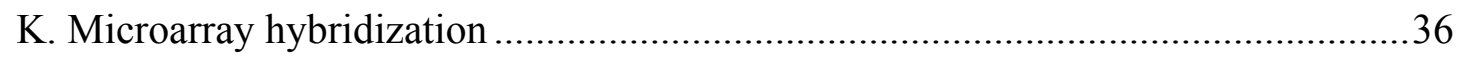

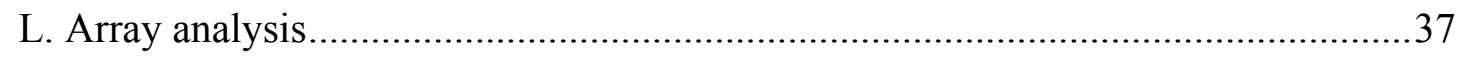

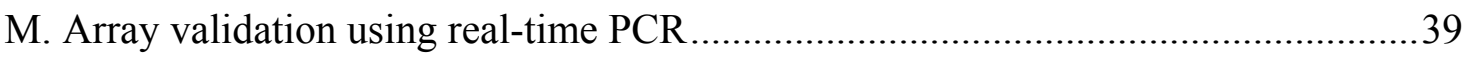

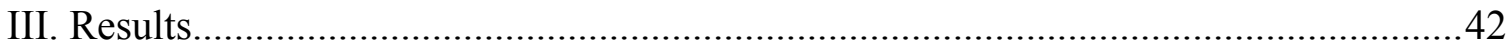

A. Density-dependence of natural competence in SK36 .......................................42

B. SK36 competence and growth is negatively affected in acidic

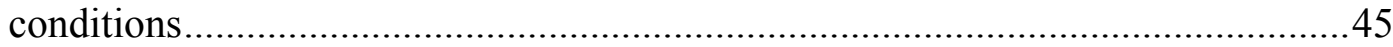

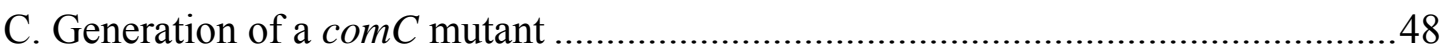

D. Determination of optimal concentration of CSP for JFP41 competence...............59

E. Density dependence of competence in JFP41 ..............................................64

F. Decay of competence after CSP treatment in JFP41 ..................................... 70

G. Microarray analysis of transcriptional regulation in response to CSP...................73

H. Putative competence genes are shown to be activated in S. sanguinis via microarray analysis in response to CSP treatment 
I. Examination of sequences upstream of highly expressed CSP-induced genes reveals a putative "com-box" for late response genes ............................................96

J. Examination of temporal regulation of selected competence genes via qRT-PCR 100

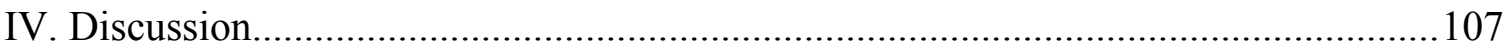

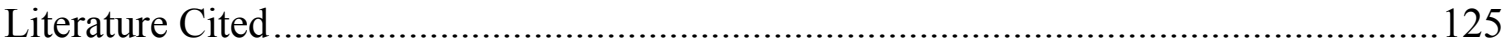

VITA 


\section{List of Tables}

Table Number:

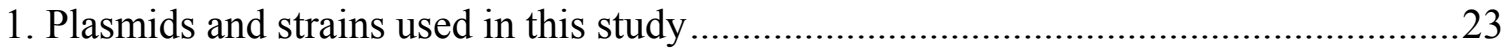

2. Primers used for the production, screening, and sequencing of JFP41 …………........29

3. Primers used for qRT-PCR verification of microarray results ......................................40

4. List of up-regulated genes in S. sanguinis in response to CSP ......................................79

5. Orthologs in S. sanguinis of genes in S. pneumoniae thought to be indispensable for competence .....................................................................................94

6. Results of a fuzznuz analysis searching for a conserved octamer upstream of

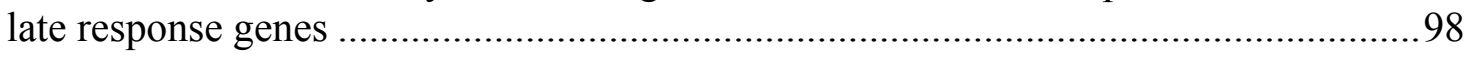

7. Sequence alignment of the regions upstream from four early response genes ............101

8. Orthologs in S. pneumoniae and S. gordonii of the 69 S. sanguinis late response genes 


\section{List of Figures}

Figure Number:

1. Schematic representation of the $S$. pneumoniae competence model adopted for this study

2. Sequence of the competence stimulating precursor peptide in seven different

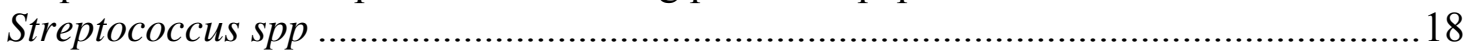

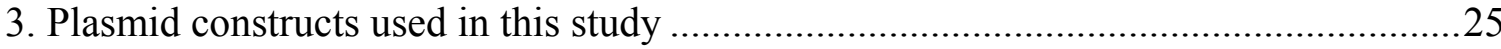

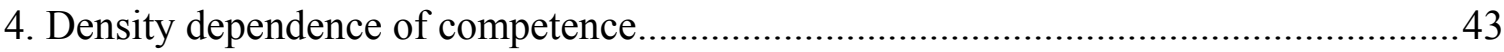

5. Effects of acidic $\mathrm{pH}$ conditions on competence and growth ....................................46

6. Flow chart depicting the construction of JFP41 …....................................................49

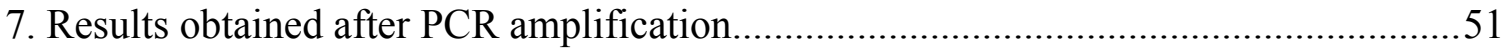

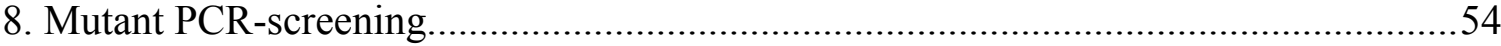

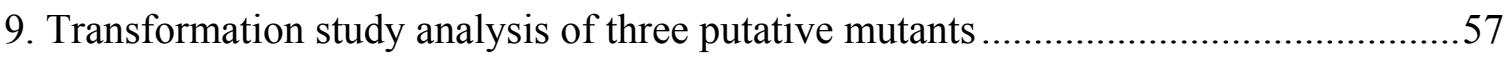

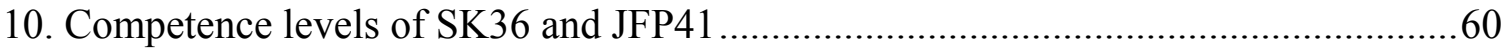

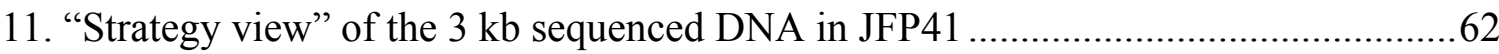

12. The effect of exogenous CSP concentration on the transformation frequency

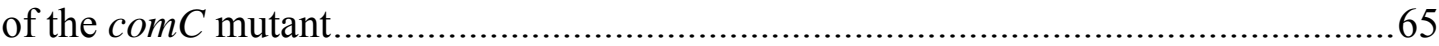

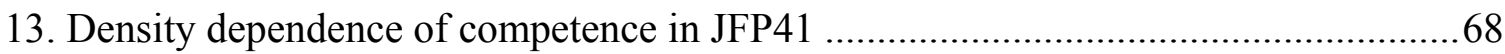

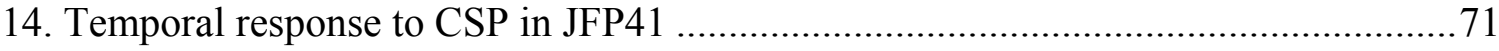

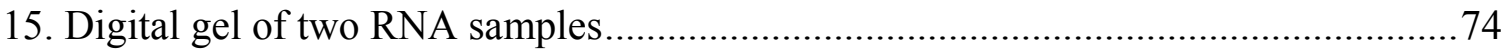

16. Examples of spots flagged during microarray analysis ....................................... 77

17. Colorimetric representation of the early and first-class late response genes..............85 
18. Colorimetric representation of second-class late response genes.............................8 87

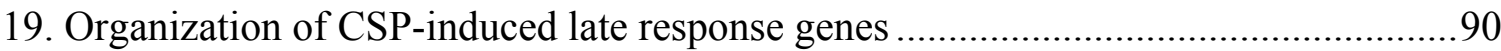

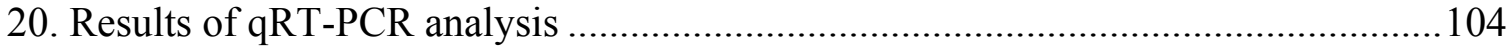




\section{List of Abbreviations}

$\alpha$

$\beta$

$\Delta$

$\%$

${ }^{\circ} \mathrm{C}$

$\mu 1$

$\mu \mathrm{g}$

$\mathrm{ABC}$

Arg

ATP

BHI

bp

BSA

cDNA

CFU

CHD

$\mathrm{Cm}$

CSP

DEPC

DNA alpha

beta

delta

percentage

degrees Celsius

microliter

microgram

ATP-binding cassette

arginine

adenosine triphosphate

brain heart infusion

base pairs

bovine serum albumin

complementary DNA

colony forming units

congenital heart disease

chloramphenicol

competence stimulating peptide

diethyl pyrocarbonate

deoxyribonucleic acid 


\begin{tabular}{|c|c|}
\hline DNAse & deoxyribonuclease \\
\hline DTT & dithiothreitol \\
\hline Em & erythromycin \\
\hline $\mathrm{EtBr}$ & ethidium bromide \\
\hline FDR & false discovery rate \\
\hline Gly & glycine \\
\hline $\mathrm{h}$ & hour \\
\hline HK & histidine kinase \\
\hline HS & horse serum \\
\hline IE & infective endocarditis \\
\hline $\mathrm{kb}$ & kilobase \\
\hline $\mathrm{kDa}$ & kiloDalton \\
\hline M & molar \\
\hline MIC & minimal inhibitory concentration \\
\hline $\min$ & minute \\
\hline $\mathrm{ml}$ & milliliter \\
\hline $\mathrm{mM}$ & millimolar \\
\hline $\mathrm{mm}$ & millimeter \\
\hline mRNA & messenger RNA \\
\hline MVP & mitral valve replacement \\
\hline $\mathrm{NaOAC}$ & sodium acetate \\
\hline
\end{tabular}




$\begin{array}{ll}\text { ng } & \text { nanogram } \\ \text { nm } & \text { nanometer } \\ \text { PBS } & \text { overnight } \\ \text { PCR } & \text { phosphate buffered saline } \\ \text { PLG } & \text { polymerase chain reaction } \\ \text { qRT-PCR } & \text { phase lock gel } \\ \text { QS } & \text { quantitative real-time PCR } \\ \text { RAD } & \text { quorum sensing } \\ \text { RHD } & \text { ramhorn array database } \\ \text { RNA } & \text { rheumatic heart disease } \\ \text { RR } & \text { ribonucleic acid } \\ \text { rRNA } & \text { response regulator } \\ \text { SAM } & \text { ribosomal RNA } \\ \text { TH } & \text { significance analysis of microarrays } \\ & \text { Todd Hewitt }\end{array}$




\begin{abstract}
PHYSIOLOGICAL AND MOLECULAR CHARACTERIZATION OF GENETIC COMPETENCE IN STREPTOCOCCUS SANGUINIS

By Alejandro Miguel Rodriguez, B.S.
\end{abstract}

A Thesis submitted in partial fulfillment of the requirements for the degree of Master of Science at Virginia Commonwealth University.

Virginia Commonwealth University, 2008

Major Director: Todd O. Kitten, Ph.D.

Associate Professor

Philips Institute of OCMB, School of Dentistry

The ability of bacteria to assimilate free DNA from the environment is known as competence. Though many studies have focused on competence regulation in Streptococcus pneumoniae and Streptococcus gordonii, Streptococcus sanguinis has yet to be examined. Physiological characterization of competence in S. sanguinis strain SK36 and its comC mutant, JFP41, led to the genome-wide transcriptional analysis of cells induced to competence via addition of competence-stimulating peptide (CSP). A total of 128 genes were induced at least 2-fold, 74 of which were classified as either "early" or "late" based on their induction patterns. Expression patterns were verified 
using qRT-PCR. This study identified genes not up-regulated in S. pneumoniae or S. gordonii and lays the foundation for bioinformatic studies to identify conserved binding sites upstream from CSP-regulated genes. These results also shed light on the possible existence and identity of expected CSP exporters in S. sanguinis, which have so far eluded discovery. 


\section{INTRODUCTION}

\section{A. Streptococci}

Over the past century, the Streptococcus genus has undergone vast changes in nomenclature and taxonomy. Much of what is known today has occurred through advances in technology. For example, one of the earliest methods to differentiate between streptococcal species was to observe their phenotypic growth on blood agar plates. The observation, first noted in 1903 by Shotmuller (23), allows for categorization of streptococci into three distinct groups based on their hemolytic properties. Alpha-hemolysis consists of a reduction of iron in hemoglobin resulting in a greenish streak across the plate. The beta-hemolytic species are those that lyse red blood cells and present as clear regions upon streaking. Lastly, the gamma-hemolytic group consists of species that show no hemolysis at all.

A major breakthrough in the categorization of the Streptococcus genera was first detailed by Lancefield (55) when she described a method of determining and consequently identifying carbohydrate group antigens that were associated with the beta-hemolytic group. In 1937, Sherman (94) grouped the streptococci into distinct groups based on their hemolytic reactions, carbohydrate antigens, and basic metabolism and tolerance tests. The result was the formation of the four groups which many scientists over the years used to categorize new streptococcal species - the pyogenic, lactic, enterococci, and viridans group. The application of $16 \mathrm{~S}$ rRNA $(2,33)$ gene sequencing and ribosomal 16S-23S intergenic spacer region sequencing (106) has 
allowed researchers to more accurately revise the classification system and create phylogenetic trees, consequently permitting precise measurements of similarity between streptococcal species.

\section{B. Viridans streptococci}

The term "oral streptococci" has been used synonymously in the past with that of the "viridans streptococci", though great care must be taken when using either as a collective term, seeing as they are not always comparable (111). Most viridans streptococci are in fact oral streptococci residing primarily within the human mouth. The oral and viridans streptococci usually colonize hard and soft tissues, and as such have been isolated not only on tooth surfaces in the oral cavity, but also in the gastrointestinal and genitourinary tracts. Although usually existing as benign commensal agents, some oral streptococcal species have been implicated in dental diseases such as periodontitis (27) and dental caries (26).

The mechanism of adherence to teeth has been extensively investigated. Typically, oral streptococci are the first to compete for colonization sites on tooth surfaces (76). Initial adherence by the early colonizers S. mitis and S. sanguinis onto tooth surfaces is believed to be the critical factor for the onset of dental plaque. It first requires the presence of salivary glycoproteins (72), such as MG2 (25) and $\alpha$-amylase (1), among others, which are part of the human salivary pellicle that coats the tooth. Murray et al. (72) suggested that bacteria that adhere to these glycoproteins are more likely involved in plaque formation. Once these early colonizers establish a permanent niche in the oral cavity, they behave as receptors and ligands for further attachment by 
other bacteria, which then aids in stronger adherence to the tooth surface. For example, Hamada et al. (34) observed that S. sanguinis (known then as S. sanguis), when bound by $S$. mutans, adhered much more strongly to glass surfaces. He also observed that upon this heterospecies interaction, S. sanguinis produced large volumes of a gelatinous polysaccharide in the presence of sucrose. This product is the basis of dental plaque, or biofilm, which creates an environment that aids in further adherence by other streptococcal species, as well as protection against the host immune response and antibiotics.

\section{Streptococcus sanguinis}

In 1997, the name $S$. sanguis drew criticism due to it being grammatically incorrect and was consequently changed to S. sanguinis (105). One of the better known members of the viridans group, S. sanguinis has been shown to be one of the very first colonizers of the human oral cavity (57). It is benign in its native niche and actually thought to be advantageous due to its antagonistic role against the dental caries inducing bacterium, S. mutans (63). Furthermore, it was postulated that a high S. mutans/S. sanguinis ratio may lead to a predisposition for development of dental caries. However, there is no conclusive data to either confirm or deny this hypothesis at the moment.

Although S. sanguinis predominates within the oral cavity, it has also been shown to enter the bloodstream. Streptococci within the oral cavity may enter the bloodstream through invasive dental procedures or through the simple act of practicing proper dental hygiene $(61,62,93)$. The problem is exacerbated if an individual is 
suffering from periodontal disease where the soft tissue surrounding the tooth easily tears. At this point, a streptococcal invasion is easily cleared by the host immune response in a healthy individual. However, in cases in which a host has suffered heart damage, host platelets aggregate on the damaged endothelium resulting in the inflammation of the heart valve due to the formation of a thrombus called a "vegetation." As has been previously shown (19), S. sanguinis may adhere to the vegetation and enlarge it, resulting in a condition known as infective endocarditis.

\section{Infective endocarditis}

Though quite rare, infective endocarditis (IE) is a life-threatening condition if left untreated. The incidence of IE in the general population per year is somewhere in the range of $1.7-7$ per $100,000(7,39,101)$ and seems to affect men (approximately 1.7:1) more so than woman (73). Approximately $42-52 \%$ of infections are caused by Streptococcus spp. $(75,115)$. The median age for those suffering from IE has increased to approximately $47-69(68,109)$ presumably due to proper dental hygienic practices becoming the norm and average life spans increasing due to advances in the medical field thus leading to longer exposure to bacteremia (73). There has been, however, a recent surge in younger patients who have a history of IV drug abuse.

Development of IE requires a preexisting condition of heart damage causing injury to the endothelial surface of the heart valve. Risk factors include rheumatic heart disease (RHD), congenital heart disease (CHD), mitral valve prolapse (MVP) with regurgitation, and cardiac valve replacement (68). Steckelberg and Wilson (95) 
discovered that patients with a prosthetic valve or who have suffered before from endocarditis were 400 times more likely to be afflicted with IE than those who had no such medical history. The likelihood of developing IE for patients suffering from MVP increases approximately 10 fold, which is significant considering the high incidence of the disease. It was also shown that in cases of RHD, the lifetime risk of acquiring IE increases from 5 to $380-440$ per 100,000 patient-years (112).

Though the intricate pathogenesis for the development of IE has been extensively investigated, the exact mechanism of complex interactions has yet to be fully elucidated. Generally, platelets aggregate to the site of the damaged endothelium on the heart valve resulting in nonbacterial thrombotic endocarditis (NBTE) (112). Oral streptococci transiently introduced into the bloodstream via trauma to the gingival crevice may adhere to the platelet aggregation through complex interactions between bacterial adhesins and receptors located on platelets. The specific adhesins required for such interactions have also been investigated. Some oral streptococci possess the sialic acid-binding adhesin, Hsa, which has been implicated not only in adherence to tooth surfaces, but also in IE $(50,100)$. In S. parasanguinis, a lipoprotein receptor antigen I (LraI) homolog, FimA, has been suggested to mediate adherence to the salivary pellicle as well as the fibrin platelet matrix (8).

Once adherence to the NBTE has taken place, cells lodge themselves into the complex and stimulate further production of fibrin on their surfaces. Adhered bacteria may also recruit cytokine and tissue factor secreting monocytes to the area which further stimulate the production of procoagulating factor VII (FVII) (5). It was 
suggested that streptococcal glucosyltransferases (GTFs) may play a role in the recruitment of monocytes by inducing the assembly of adhesion molecules and stimulating IL-6 production (114). The process continues, resulting in the overall increase of the vegetation allowing bacterial cells to sustain replication, impervious to the host immune response. Adhered cells replicate as rapidly as bacteria in broth cultures (112) resulting in vegetations with a bacterial density of up to $10^{8} \mathrm{CFU}$ per gram (74). Just like in any biofilm, cells in the vegetation are mostly metabolically inactive, rendering treatment with antibiotics difficult.

Clinical manifestations of those suffering from IE may be somewhat difficult to interpret. Patients may complain of fever, chills, muscle and joint aches, fatigue, and loss of appetite; all symptoms of infection with the common flu. In cases where the patient suffers from congestive heart or renal failure, or has recently used antimicrobial drugs, fever may be minimal or non-existent (73). However, a more telling sign is the discovery of a heart murmur during physical examination and observation of the peripheral manifestations of IE. Signs include petechiae on the skin or conjunctivae and splenomegaly. Even so, patients with right-sided endocarditis do not exhibit such peripheral symptoms (73).

In patients suspected of suffering from IE, several examinations may be performed for a definitive diagnosis. In 1994, Durack et al. (20) at Duke University came up with a method that integrated the clinical symptoms, laboratory work, and echocardiogram examination - consequently known as the "Duke criteria" - to successfully screen patients for IE. The criteria called for the positive identification of 
IE via an echocardiogram or the presence of commonly associated bacteria in blood cultures such as Streptococcus spp. and Staphylococcus spp., as well as the symptoms detailed above. The criterion has consequently been utilized effectively in numerous studies. However, due to the development of the more sensitive transesophageal echocardiogram (TEE), the increasing number of patients categorized as "possible", the role of Staphylococcus aureus bacteremia in endocarditis, and the improper identification of culture-negative cases, a more recent modification to the Duke criteria was proposed (58).

Treatment of patients who have been diagnosed with IE can be difficult. Blood cultures are taken to identify which species is responsible for IE in the patient, followed up with an antimicrobial susceptibility test to determine the minimal inhibitory concentration (MIC) of the drugs of choice (73). As an example, for patients with native valve endocarditis and an MIC of penicillin $<0.1 \mu \mathrm{g} / \mathrm{ml}$, administering penicillin $\mathrm{G}$ and gentamicin for two weeks is usually sufficient (29). For the most part, treatment is usually started in the hospital and continued as an outpatient. More invasive procedures must be followed for patients who suffer from congestive heart failure.

Over the past few decades, the American Heart Association has suggested different prophylaxis treatments in preparation for dental procedures; the penultimate recommendation coming in 1997 (16). However, even with these proposals, the incidence of IE over the years has not been alleviated. Furthermore, very little published data are available suggesting a definitive link between prophylaxis and prevention of IE. Most studies have focused on dental procedures due to the belief that bacteremia 
caused by a tooth extraction, for example, was much higher in intensity than that resulting from daily routine cleaning. Studies, have shown a significant increase in bacteremia levels after dental procedures $(28,61,93)$. However, one study showed that bacteremia for these procedures was as low as pre-extraction levels (91), suggesting much lower bacteremia than previously thought. Due to the emergence of penicillin resistant strains, there as been a more recent emphasis on good oral hygiene for the prevention of IE, rather than the application of antibiotics before dental treatment (28, 90). Considering the emergence of antibiotic resistant strains, the low incidence of IE in the general population, and the lack of evidence linking antibiotic prophylaxis with prevention of IE, the American Heart Association has made recent alterations to its recommendations, such that only patients with a narrowed set of underlying heart conditions are recommended to be given some form of prophylaxis before dental procedures involving manipulation of gingival tissue or perforation of the oral mucosa (112). These recommendations take into account the conditions for which there exists the highest risk of adverse outcomes from IE.

\section{E. Competence in streptococci}

\section{Definition and history}

The ability of any given bacterium to uptake and incorporate free extracellular DNA from the environment - also known as 'naked DNA' - is known as competence and may play a critical role in bacterial adaptation and evolution in its native niche.

DNA is usually released upon cell lysis and can be integrated into a host cell genome. If 
this results in genotypic changes, the host cell is said to have been transformed. The observation of transformation was first noted by Griffith (32) when he discovered that a pathogenic pneumococcal strain - today referred to as $S$. pneumoniae - could be destroyed and somehow transform nonpathogenic strains into the pathogenic type. In 1944, Avery et al. (4) observed that the transforming factor hypothesized by Griffith was actually DNA. This study was one of the earliest examples giving credence to the idea that DNA was in fact responsible for carrying genetic information.

\section{Genes associated with competence}

Since its first discovery, extensive investigation into the transformation capability of S. pneumoniae has been very well documented. It was first noted that transformation appeared to be cell density-dependent, and that it occurred abruptly and decayed over time (104). The idea that a system is governed by cell density fits in line with the quorum sensing (QS) system model whereby bacteria communicate with each other in order to adapt to a given environmental cue. Indeed, many studies have shown a direct link between S. pneumoniae competence and the QS system $(56,69,103)$. Further observation by Tomasz (103) led to the hypothesis that the system was regulated by some secreted autocatalytic macromolecule. It was also shown that this competence factor could be isolated from filtrates (102). The induction of competence was shown in the presence of this activator and was lacking when the activator was absent (103). Subsequent studies finally isolated a competence stimulating heptadecapeptide (CSP) which was found to be encoded by comC (35) and was confirmed to stimulate competence in S. pneumoniae (81). 
Analysis of the com locus, discovered via insertion-duplication mutagenesis (10), revealed two genes, comA and $\operatorname{comB}$, which encoded proteins of $77 \mathrm{kDa}$ and 49 kDa respectively (11). Deletion of either was shown to abolish natural competence, though function was restored in the presence of exogenous CSP (10). Predictions made via analysis of the $\operatorname{com} A$ sequence revealed that it belonged to a superfamily of ATPdependent transport proteins, also termed ATP-binding cassette (ABC-type) transporters (42) suggesting that these genes encode for the transport system responsible for the exportation of CSP into the extracellular space. ComA and ComB, associated with CSP secretion, were shown to resemble transporters that secrete double-Gly bacteriocins (43). Initially, CSP in S. pneumoniae is produced as a 41 amino acid precursor peptide and is subsequently cleaved yielding a 17 amino acid peptide which is then transported into the external milieu via ComA with the help of the accessory protein ComB (35). Further investigations revealed that the protease component responsible for this cleavage resides within ComA (46).

Sequencing of the comC downstream region revealed two putative ORFs designated comD and comE (81). Homology searches revealed that these two genes belong to a family of previously described two-component regulatory systems (98). ComD shared vast homology with a transmembrane histidine kinase (HK) receptor protein, while comE was similar to a response regulator (RR) (81). Briefly, as HK becomes activated, adenosine triphosphate (ATP) phosphorylates the histidine residues on the HK protein which in turn donates a phosphoryl group to an aspartic acid residue in the RR (98). It was postulated that as CSP reaches a critical threshold in the 
environment, it binds to the HK receptor, which in turn activates the RR. Therefore, ComE up-regulates transcription of the com genes - comAB and comCDE - behaving in a positive feedback loop (81). The hypothesis was supported in another study by Håvarstein et al. (37) which concluded that ComD was in fact the CSP receptor and by Ween et al. (110) who demonstrated the DNA binding and autocatalytic function of ComE. Researchers in the latter study also created a model looking at conserved regions based on upstream sequences of comCDE in different streptococcal species. It was suggested that the putative ComE binding site, also known as the ComE box, was a 9bp direct repeat of aCAtTTcaG, with the two sequences separated by no more than 12 bp.

Genomic sequencing, biochemical characterization, and bioinformatic approaches have allowed investigators to identify many different genes associated with DNA uptake and recombination, including comEA, comEC, cilA, cilB, cilD, cilE, and coi $(9,56,82)$. Analysis of the upstream section of these genes revealed a highly conserved eight nucleotide long sequence - TACGAATA - known as the com-box, at the -10 position, and that it was crucial for the induction of transcription (9). Lee et al. (56) noted that this highly conserved sequence preceded only these genes and not in $\operatorname{com} A B$ or $C o m C D E$ suggesting that transcription was not ComE dependent. Investigations using purified pneumococcal RNA polymerase holoenzymes revealed a protein associated with cilA transcription, named ComX. It was observed that ComX was ComE-dependent, and was not an autoinducer. Furthermore it was suggested that ComX behaved as an alternate sigma factor regulating transcription of downstream 
genes responsible for the DNA processing phase of competence (56). The competence genes were distributed into two categories based on their temporal expression. "Early" response genes were shown to be those that were ComE dependent (e.g. com $A B$ and comCDE), while the majority of "late" com genes were those that carry a com-box within their promoters and are thus ComX dependent $(3,84,89,108)$.

\section{DNA uptake machinery}

It has been shown in S. pneumoniae that cells induced to competence behave as recipients for foreign DNA, while a sub-fraction of the population lyse and act as donors (96). It was further shown that cells lysing were non-competent and seemed to be more affected as the population of competent cells increased (97). As cells lyse, their DNA becomes subject to uptake by these competent cells. The mechanism for DNA uptake has been extensively studied in both Bacillus subtilis and S. pneumoniae. Typically, a competence pseudopilus, encoded by the seven-gene comG operon (18), allows access of dsDNA to DNA receptor proteins on the surface of these competent cells. ComEA is a transmembrane protein which contains an exposed C-moiety at the outer surface which likely binds with DNA $(6,44)$, although in $S$. pneumoniae, a transposon insertion in this gene diminished, but did not eliminate, DNA attachment onto cell surfaces (6) suggesting the presence of other DNA receptors. In streptococcal species, the transmembrane complex is encoded by a four-gene operon; comYA-D in $S$. gordonii for example (82).

In B. subtilis, the attachment of dsDNA to the cell surface is followed immediately by double-stranded cleavages by the nuclease, NucA (86). In $S$. 
pneumoniae the endonuclease responsible for the cleavage of dsDNA prior to its transportation across the cell-wall has not been elucidated. However, studies have shown that prior to DNA transport, single-strand nicks are created (53) followed by double-strand breaks (70). It was observed in S. pneumoniae that ssDNA was linearly transported with 3'- 5' polarity (67), that it occurred at approximately the same rate as the degradation of the second strand, and that this degradation proceeded with opposite polarity (66). It was discovered that the nuclease responsible for this degradation was encoded by endA $(54,87)$. Linear DNA is then transported into the cytoplasm through ComEC, a polytopic membrane protein postulated to form an aqueous channel for DNA to transverse (17). Once inside the cell, integration into the host genome is thought to be a RecA-dependent process requiring sequence homology between the foreign DNA and host chromosomal DNA. This hypothesis was further supported through studies showing that competence is abolished in a RecA deficient mutant (83). The model of competence regulation used for this study can be seen in Figure 1.

\section{Difference in competence regulation in $S$. mutans with respect to $S$. pneumoniae}

As stated earlier, much of what is known of natural competence has been learned from studies in both B. subtilis and S. pneumoniae. Due in part to the emergence of whole genome sequences, there has been an explosion of information regarding competence in different streptococcal species. There is extensive evidence suggesting that the mechanism regulating competence is similar in streptococci belonging to the mitis and anginosus groups (38). Species in these groups contain a similar comCDE operon which is typically flanked by the tRNA-Arg or tRNA-Glu genes. Unlike $B$. 
Figure 1. Schematic representation of the S. pneumoniae competence model adopted for this study.

1.) comC is transcribed resulting in the translation of the precursor competence stimulating peptide (CSP).

2.) CSP binds to its target, the product of $\operatorname{com} A B$, where the signal peptide is cleaved. As a result, CSP is transported into the external milieu.

3.) As the concentration of CSP builds in the extracellular space, it ultimately binds to the histidine kinase receptor encoded by comD. This interaction causes the phosphorylation of the histidine residues and activation of the ComD receptor.

4.) ComD then transfers the phosphate group unto an aspartic acid residue in the response regulator encoded by comE. ComE then activates transcription of the $\operatorname{com} A B$ and comCDE operons, as well as the alternate sigma factor encoded by $\operatorname{comX}$.

5.) ComX in turn activates the transcription of genes responsible for the uptake of DNA. 6.) Included among these are the $c o m Y$ genes encoding a pseudopilus. The pseudopilus is thought to be required for the initial interaction between DNA and DNA receptor proteins on the surface of the cell. 
Figure 1

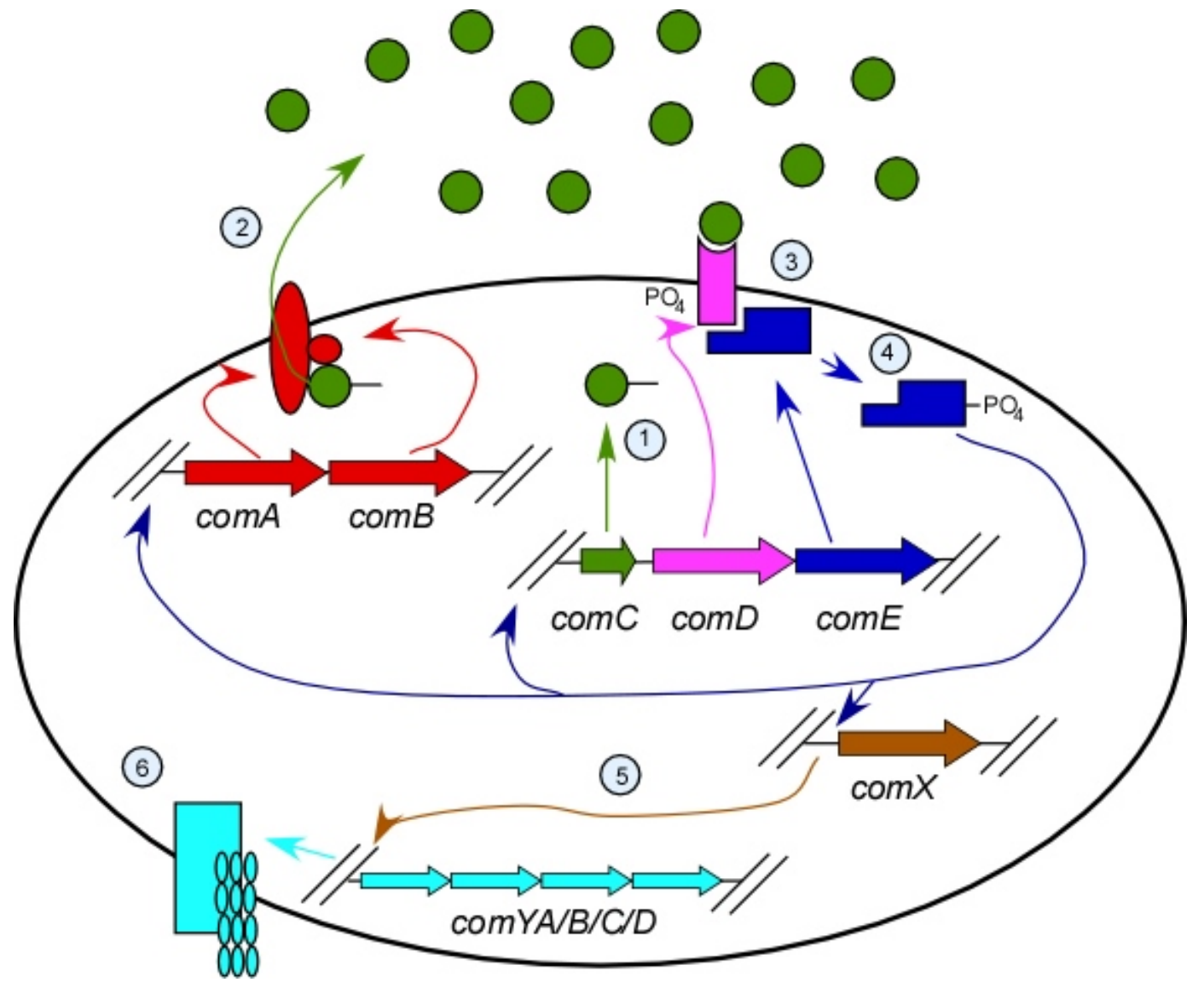


subtilis, competence characteristically occurs at early- to mid- log phase as observed in S. pneumoniae (38) and S. gordonii (65). There seems to also be a correlation between $\mathrm{pH}$ of the media and competence $(12,104)$ in S. pneumoniae.

Extensive study of the competence system in S. mutans in recent years has been conducted to observe any differences in the systems between the two groups. For the most part, the mechanism of quorum sensing appears to be similar to that of $S$. pneumoniae (15). A key difference between the two, however, is the product encoded by comC. Whereas in S. pneumoniae a 17 -amino acid competence stimulating peptide is cleaved from a 41-amino acid precursor, in S. mutans a 46-amino acid precursor is encoded by comC yielding a 21-amino acid mature peptide after cleavage (59). Interestingly, the mature peptide also contains the double Gly-motif exhibited in other streptococcal species.

In general, transformation frequencies in S. mutans are much lower than in other streptococci $(64,71)$. Interestingly, it has been observed that addition of S. mutans CSP to $S$. mutans induces coordinated expression of genes involved in competence and mutacin IV (48), a nonlantibiotic bacteriocin (88). The findings suggest that during the competent phase, S. mutans acquires DNA from its environment by lysing surrounding non competent $S$. mutans cells as well as cells that are phylogenetically similar, such as S. gordonii (47).

On the regulatory front, whereas com $A B C D E$ partake in a positive feedback loop with ComE serving as the auto-catalyst in S. pneumoniae, in S. mutans non phosphorylated ComE represses comC while simultaneously up-regulating production 
of the bacteriocin encoding $n \operatorname{lm} C$ gene (52). In the presence of CSP however, ComE is activated resulting in expression of comC. It was later hypothesized that unlike what has been previously described for S. pneumoniae, comC does not lie in the same operon as comDE. Though mutations in comC and comDE negatively affect competence in $S$. mutans (59) just like in other streptococcal species, the repressive role of ComE suggests a unique mode of competence regulation compared to $S$. pneumoniae.

\section{Putative com genes in $S$. sanguinis}

In 1997, Gaustad and Havardstein (30) located comC in S. sanguinis and determined the theoretical sequence of the translated protein. Unlike what has been observed in other streptococcal species, the presumed mature 15 -amino acid $\left(\mathrm{NH}_{2}-\right.$ DLRGVPNPWGWIFGR-COOH) competence stimulating peptide lacks the signature double-Gly motif (38). The Gly-Gly motif has been thought to be the site that is cleaved during export by dedicated ABC-type transporters (36). Nevertheless, the presumed mature peptide was synthetically produced in a laboratory, and shown to induce competence specifically in S. sanguinis (38). A visual example showing the differences between ComC of S. sanguinis and that of other streptococcal species can be seen in Figure 2.

It was previously noted that the supernatant from cultures of group H S. gordonii strain Challis would not increase the number of observable transformants in cultures with naturally competent group F strains, indicating a level of pheromone specificity (80). In S. sanguinis, CSP synthesized using the predicted mature peptide sequence was shown to specifically induce competence in S. sanguinis, but not in S. gordonii nor in $S$. 
Figure 2. The competence stimulating precursor peptide in seven different Streptococcus spp. The leader peptides are underlined signifying the presumed site of cleavage which is represented by a "_.". 
Figure 2

S. gordonii

S. mutans

S. pneumoniae

S. mitis

S. infantis

S. oralis

S. sanguinis
MKKKNKQNLLOKELQQFEILTERKLEQVTGG - DVRSNKIRLWWENIFFNKK MKKTLSLKNDFKEIKTDELEI I IGG-SGSLSTFFRLFNRSFTQALGK MKNTVKLEQFVALKEKDLQKIKGG-EMRLSKFFRDFILQRKK MKNTVKLEQFKEVTEAELQEIRGG - DWRISETIRNLIFPRRK MEKTVKLEQFKKLTEKELQEIQGG - DWRFLNSIRDLIFPKR MKNTVKLEQFVALKEKDLQEIKGG-EMRLPKILRDFIFPRKK MKIYSFQIALNSNSLVQTFW-DLRGVPNPWGWIFGR 
milleri (30) giving further support to this observed specificity. In S. pneumoniae, two unique variants of CSP and ComD have been identified (CSP1 and CSP2; ComD1 and ComD2) (85). It was observed that addition of synthetic CSP1 to cells carrying ComD2 was 200 times less potent than when it was added to cells carrying ComD1 (49), indicating that not only is CSP species-specific, but that it may also be strain specific. It was later proposed that a hydrophobic region within the peptide which is unique in many different streptococcal species may contribute to the specificity of each CSP for its cognate ComD receptor (49).

The genome of S. sanguinis has been recently sequenced (113). It was determined that this streptococcal species had the largest genome of the sequenced streptococci, and that it contained approximately 2,274 putative proteins, $61 \mathrm{tRNAs}$, and four rRNA operons. It was also shown to share 23 more proteins with $S$. mutans than with S. pneumoniae. Though it was discovered to contain orthologs for 20 of the 22 indispensable genes essential for competence in S. pneumoniae (83), the most notable absence was the comAB operon and comW. The ComW protein has been thought to activate and stabilize ComX (99). The absence of $\operatorname{com} A B$, at least through initial observation of the genome, is not entirely surprising considering the unique sequence of the precursor peptide. The predicted unique cleavage site shown in Figure 2 for this peptide may indicate a unique transportation system in S. sanguinis not seen in any other streptococcal species. However, whether or not this presents the actual site of cleavage or even if S. sanguinis CSP is cleaved at all has yet to be determined. 


\section{F. Specific Aims}

The aim of this project is to characterize genetic competence in S. sanguinis. Though extensively studied in S. pneumoniae, the regulation of competence at the molecular level has not been fully elucidated in S. sanguinis. Considering the implications of a naturally competent organism in the oral environment, and the fact that $S$. sanguinis is one of the first colonizers of the human mouth as well as having been implicated in the cause of infective endocarditis, the necessity to study the adaptable nature of this organism becomes immediately apparent. A transcriptome analysis of competence induction via the addition of exogenous CSP would give great insight into the regulatory mechanism governing competence in S. sanguinis. It would also allow the possible identification of the unknown proteins that process and export CSP in S. sanguinis. 


\section{MATERIALS AND METHODS}

\section{A. Plasmids and strains}

A list of plasmids and strains used in this study is shown in Table 1.

Streptococcus sanguinis wild type strain, SK36, was selected for genome sequencing based on multiple criteria (113), including keeping with common characteristics that define S. sanguinis using accepted diagnostic tests, and virulence in the rat model of IE. SK36 was consequently selected for this study based on the availability of the genome sequence. A comC knockout strain was created and named JFP41 (see below). Plasmid pJFP16 (78), kindly provided by Dr. Sehmi Paik, contains a chloramphenicol $(\mathrm{Cm})$ acetyltransferase (cat) gene within a mini-transposon. The mini-transposon is nestled within approximately $1.9 \mathrm{~kb}$ of flanking DNA homologous to $n r d D$ ( $~ 950 \mathrm{bp}$ on either side). The plasmid also contains a kanamycin resistance gene, $a p h A-3$, in the same orientation as cat. Plasmid pJFP36 (manuscript in preparation), kindly donated by Lauren Turner, is a 5.5-kb plasmid containing an erythromycin resistance cassette, pSerm. NcoI restriction sites are integrated at the 3' and 5' end of the erm construct which has been situated within SSA_0169. A total of $1.3 \mathrm{~kb}$ of flanking DNA (740 bp upstream and $620 \mathrm{bp}$ downstream of the erm cassette) are also inserted into the plasmid. Maps of each plasmid are shown in Figure 3.

\section{B. Bacterial cultivation}

SK36 and JFP41 were grown at $37^{\circ} \mathrm{C}$ - either anaerobically for $24 \mathrm{hrs}$ or at $6 \%$ $\mathrm{O}_{2}$ for 48 hrs - on Brain Heart Infusion (BHI) broth (Bacto ${ }^{\mathrm{TM}}$, Sparks, MD.) 
Table 1. Plasmids and strains used in this study 
Table 1

\begin{tabular}{|c|c|c|}
\hline $\begin{array}{l}\text { Strains and } \\
\text { plasmids }\end{array}$ & Phenotype & Reference \\
\hline \multicolumn{3}{|l|}{ Strain } \\
\hline \multicolumn{3}{|l|}{ S. sanguinis } \\
\hline SK36 & $\begin{array}{l}\text { Human dental plaque isolate, adhesive to saliva-coated } \\
\text { HA }\end{array}$ & $(41,51,113)$ \\
\hline JFP41 & $\Delta c o m C$, derived from SK36 & This study \\
\hline \multicolumn{3}{|l|}{ Plasmids } \\
\hline pJFP16 & $\begin{array}{l}\mathrm{Cm}^{\mathrm{R}} \text { and } \mathrm{Kn}^{\mathrm{R}} \text { encoded by cat and aphA-3 genes } \\
\text { respectively in the same orientation; containing } \\
\text { nrdD1::cat }\end{array}$ & $\begin{array}{l}\text { Dr. Sehmi Paik } \\
\text { (78) }\end{array}$ \\
\hline pJFP36 & $\begin{array}{l}\mathrm{Kn}^{\mathrm{R}} \text { and } \mathrm{Em}^{\mathrm{R}} \text {; derivative of } \mathrm{pJFP} 34 \text { with } p \text { Serm ligated } \\
\text { into SSA_0169 }\end{array}$ & $\begin{array}{l}\text { Lauren Turner } \\
\text { (manuscript in } \\
\text { preparation) }\end{array}$ \\
\hline
\end{tabular}


Figure 3. Map of A) pJFP16 and B) pJFP36 reproduced with permission. 
Figure 3

A.

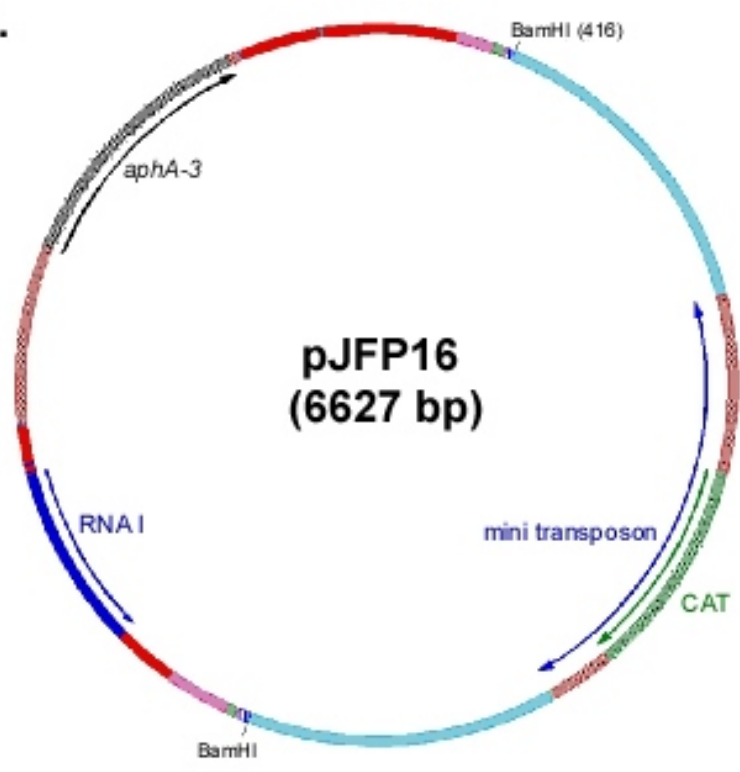

B.

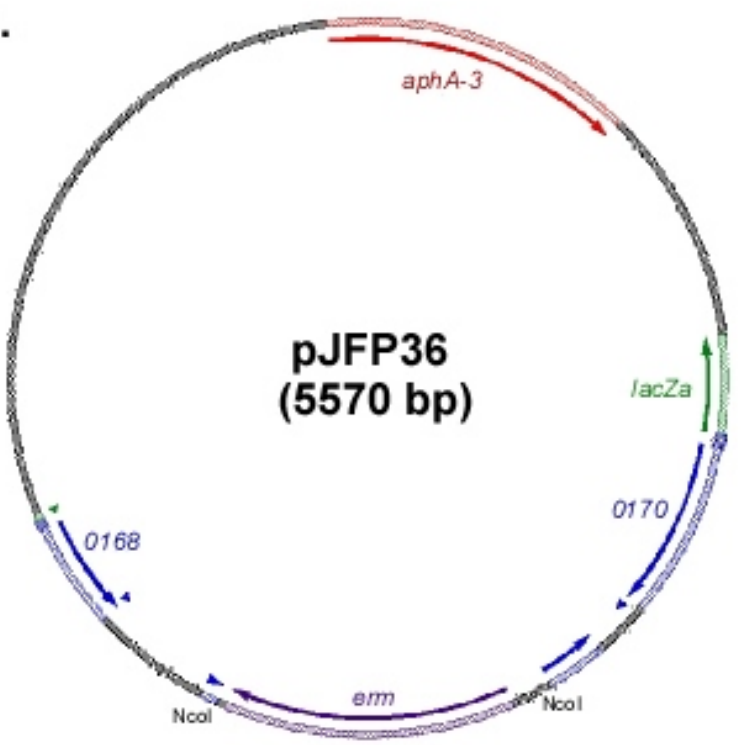


supplemented with $1.5 \%(\mathrm{w} / \mathrm{v})$ agar for colony growth on plates, unless otherwise indicated. For transformation protocols, strains were grown overnight $(\mathrm{O} / \mathrm{N})$ at $37^{\circ} \mathrm{C}$ aerobically in Todd Hewitt (TH) broth (Bacto ${ }^{\mathrm{TM}}$, Sparks, MD.) supplemented with $2.5 \%(\mathrm{v} / \mathrm{v})$ horse serum (HS) (Invitrogen, Grand Island, NY).

\section{Transformation assays}

Transformation was performed as previously described (79) for mutant creation, or using a slightly modified protocol for competence assessment. For the latter, unless otherwise indicated, $\mathrm{O} / \mathrm{N}$ cultures of each strain was diluted 1:200 into pre-warmed $\mathrm{TH} \cdot \mathrm{HS}(\mathrm{pH} 7.6)$ and incubated at $37^{\circ} \mathrm{C}$ until the optical density at $660 \mathrm{~nm}\left(\mathrm{OD}_{660}\right)$ reached $\sim 0.07$. A total of $330 \mu 1$ of culture was then transferred into a pre-warmed 0.7 $\mathrm{ml}$ microfuge tube containing 10ng of pJFP16 or pJFP36, and 70ng of S. sanguinis CSP (30). In order to eliminate any extracellular DNA, cells were allowed to incubate at $37^{\circ} \mathrm{C}$ for $20 \mathrm{~min}$ before the addition of DNAseI $\left(10.5 \mathrm{ng} \mu \mathrm{l}^{-1}\right)$. The cells were then incubated an additional 10 min before being serially diluted in PBS and layer plated.

\section{Layer plating}

For the transformation assays, $12.5 \mathrm{ml}$ aliquots of sterile molten low-meltingpoint agarose (Promega) dissolved in Tryptic Soy Broth $\left(\right.$ Bacto $\left.^{\mathrm{TM}}\right)(1 \% \mathrm{w} / \mathrm{w})$ were stored overnight at $37^{\circ} \mathrm{C}$. After serial dilutions were performed on post-transformed cells, $0.1 \mathrm{ml}$ was then transferred to these aliquots, mixed, and dispensed into Petri dishes $(100 \times 15 \mathrm{~mm}$ plates, Fisherbrand $\mathbb{R})$. The agar was allowed to solidify and subsequently incubated for $2 \mathrm{~h}$ at $37^{\circ} \mathrm{C}$. An additional $12.5 \mathrm{ml}$ of TSA \pm chloramphenicol $(\mathrm{Cm})\left(10 \mu \mathrm{g} \mathrm{ml}^{-1}\right.$; final concentration $\left.5 \mu \mathrm{g} \mathrm{ml}^{-1}\right)$ or erythromycin $(\mathrm{Em})$ 
$\left(20 \mu \mathrm{g} \mathrm{ml}^{-1}\right.$; final concentration $\left.10 \mu \mathrm{g} \mathrm{ml}^{-1}\right)$ was added to each plate. Transformation frequency was determined after $48 \mathrm{~h}$ of incubation and expressed as the total number of

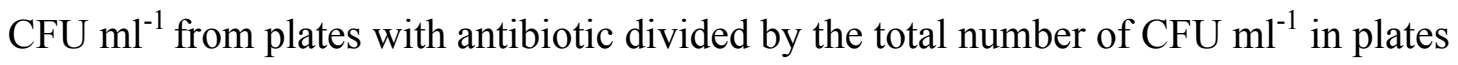
with no antibiotics.

\section{E. Growth curve in acidic medium}

In order to determine whether acidic conditions had adverse affects on SK36, a growth curve assay was performed. SK36 was grown $\mathrm{O} / \mathrm{N}$ in $\mathrm{TH} \cdot \mathrm{HS}(\mathrm{pH} 7.6)$ at $37^{\circ} \mathrm{C}$. The culture was diluted 1:100 in pre-warmed $\mathrm{TH} \bullet \mathrm{HS}$ at either $\mathrm{pH}=7.6$ or $\mathrm{pH}=6.9$ in a 96-well plate and left to incubate at $37^{\circ} \mathrm{C}$ in a FLUOstar plate reader (BMG LabTechnologies) where the $\mathrm{OD}_{450}$ was recorded every 10 minutes immediately following shaking in order to re-suspend the culture. Values were obtained by subtracting the average of three background wells. Blanks were created by adding $2 \mu 1$ of $\mathrm{TH} \cdot \mathrm{HS}(\mathrm{pH}=7.6)$ to $198 \mu \mathrm{l}$ of acidic or neutral $\mathrm{TH} \bullet \mathrm{HS}$. Three biological replicates were used and each contained three technical replicates in the 96-well plate.

\section{F. Construction of JFP41}

In order to control the competence state in SK36 and study its regulation, comC was targeted for deletion. Manipulation of the genome was accomplished via Gene Splicing by Overlap Extension ("gene SOEing") (40). All primers used for this study are listed in Table 2. In order to generate JFP41, two sets of primers were developed to amplify the upstream and downstream regions of comC. Primer ComC-B contained an 18-bp 5' tail fully complimentary to the first 18-bp of primer ComC-C. Both primers were created with the intention that the final product would ultimately fuse the start 
Table 2: Primers used for the production of JFP41 and subsequent screening and sequencing of selected mutants. 
Table 2

\begin{tabular}{|c|c|c|c|}
\hline Primer Name & Sequence $\left(5^{\prime}-3^{\prime}\right)$ & Primary Use & $\begin{array}{c}\text { Used in } \\
\text { sequencing }\end{array}$ \\
\hline ComC-A & CGAACAAGAATACCTGATT & $\begin{array}{l}\text { Deletion of } \\
\text { comC }\end{array}$ & Yes \\
\hline ComC-B* & $\frac{\text { TCCAATTATTTCAAGTGACAT }}{\text { TAACTATCTCCTATCTTTTTA }}$ & $\begin{array}{l}\text { Deletion of } \\
\text { comC }\end{array}$ & No \\
\hline ComC-C & TCACTTGAAATAATTGGATTA & $\begin{array}{l}\text { Deletion of } \\
\text { comC }\end{array}$ & No \\
\hline ComC-D & TGGCACTCTCAATAGCA & $\begin{array}{l}\text { Deletion of } \\
\text { comC }\end{array}$ & Yes \\
\hline FWD-1 & TCTAAGCGAACGGTC & PCR screening & Yes \\
\hline RVS-1 & CGGAACTATAATCTCAAGA & PCR screening & Yes \\
\hline Chkup-1 & TCATATAAAAACTCTACTG & Sequencing & Yes \\
\hline Chkdn-2 & ACTAATGTAGTAACATAATTC & Sequencing & Yes \\
\hline Chkup-3 & GATTGCCGTCAAGATTACTT & Sequencing & Yes \\
\hline Chkdn-4 & CTTTTTATGTCTGTCAATTGA & Sequencing & Yes \\
\hline Chkup-5 & AGAGATTTAAAATCAGCC & Sequencing & Yes \\
\hline Chkup-7 & GTGGGTGTTGGTTACCAG & Sequencing & Yes \\
\hline
\end{tabular}

*Note: underlined region is the 5' tail used as a self-primer in the second round of PCR amplification 
codon of the comC gene with the second codon of the comD gene. In so doing, the comC gene would be eliminated. Platinum ${ }^{\circledR}$ PCR Supermix High Fidelity (Invitrogen) was used for the subsequent PCR amplification rounds. A temperature gradient was used for the first PCR round to ensure optimal amplification. PCR profile used for the first amplification process was as follows: one cycle at $95^{\circ} \mathrm{C}$ for $4 \mathrm{~min}$, followed by 30 cycles of amplification $\left(95^{\circ} \mathrm{C} 45 \mathrm{~s}, 50^{\circ} \mathrm{C}-60^{\circ} \mathrm{C} 45 \mathrm{~s}\right.$, and $\left.68^{\circ} \mathrm{C} 2 \mathrm{~min}\right)$, followed by $68^{\circ} \mathrm{C}$ for $7 \mathrm{~min}$ and $20^{\circ} \mathrm{C}$ hold. The second round of PCR to piece both products together had a similar PCR profile with the exception of having the annealing temperature set at $55^{\circ} \mathrm{C}$ and the extension step lasting $3 \mathrm{~min}$.

Before and after the final PCR amplification round, the products were purified using MiniElute ${ }^{\circledR}$ PCR Purification Kit (Qiagen) per manufacturer's protocol. The samples were electrophoresed on a $0.8 \%$ Ultrapure $^{\mathrm{TM}}$ agarose gel (Invitrogen) and compared to mass standards to determine final concentration. The product was then diluted to working concentrations $\left(5 n g \mathrm{l}^{-1}\right)$. To incorporate this linear DNA into SK36 genome via homologous recombination, 10ng of product was used. SK36 was transformed using the protocol described above.

\section{G. Screening and identification of mutants}

With no marker in place to select for putative mutants via antibiotic selection, PCR screening was required. Whole-cell preps were performed on isolated colonies by inoculating $1.25 \mathrm{ml}$ of $\mathrm{BHI}$ per well in a 48 -well block and incubating at $37^{\circ} \mathrm{C} \mathrm{O} / \mathrm{N}$ in $6 \% \mathrm{O}_{2}$. After vortexing to re-suspend the inoculum, $1 \mathrm{ml}$ was then transferred to $1.5 \mathrm{ml}$ microfuge tubes, centrifuged at 18,000 x g for 2 min., and the pellet washed twice in 10 
$\mathrm{mM}$ Tris- $\mathrm{Cl}$ ( $\mathrm{pH} 8.0)$. After centrifugation, the pellet was once again re-suspended in 10 $\mathrm{mM}$ Tris- $\mathrm{Cl}$ and stored at $-20^{\circ} \mathrm{C}$ until use.

Two primers, FWD-1 and RVS-1, were utilized that flanked the comC gene (Table 2). A total of $1.2 \mu 1$ of the cell-preps were used as template for the PCR amplification step. The PCR profile used was as follows: one cycle at $95^{\circ} \mathrm{C}$ for $4 \mathrm{~min}$, followed by 30 cycles of amplification $\left(95^{\circ} \mathrm{C} 45 \mathrm{~s}, 51^{\circ} 45 \mathrm{~s}\right.$, and $\left.72^{\circ} \mathrm{C} 30 \mathrm{~s}\right)$, followed by $72^{\circ} \mathrm{C}$ for $7 \mathrm{~min}$ and $20^{\circ} \mathrm{C}$ hold. The samples were then run on a $1.4 \%$ agarose gel and stained with ethidium bromide $(\mathrm{EtBr})$.

To ensure that the mutant had no downstream effects on flanking genes, transformation studies were conducted on suspected mutants. Three putative mutants were selected and grown $\mathrm{O} / \mathrm{N}$ in $2 \mathrm{ml} \mathrm{BHI}$ at $37^{\circ} \mathrm{C}$ in $6 \% \mathrm{O}_{2}$. The strains were then diluted 1:200 in TH・HS and grown until an $\mathrm{OD}_{660}$ of 0.07 was reached. A total of $330 \mu 1$ of culture was then transferred to $0.7 \mathrm{ml}$ microfuge tubes containing $\pm 10 \mathrm{ng}$ pJFP3 6 and $\pm 70 \mathrm{ng}$ CSP. The cells were allowed to incubate for $1.5 \mathrm{~h}$ in a $37^{\circ} \mathrm{C}$ water bath before being diluted 1:100 into the wells of a 96-well plate containing $\mathrm{BHI} \pm \mathrm{Em}\left(10 \mu \mathrm{g} \mathrm{ml}^{-1}\right)$. The cells were grown $\mathrm{O} / \mathrm{N}$ at $37^{\circ} \mathrm{C}$ in a FLUOstar plate reader (BMG LabTechnologies) where the cultures were shaken every 10 minutes and the $\mathrm{OD}_{450}$ recorded. Values were obtained by subtracting the average of three background wells. Blanks were created by adding $2 \mu \mathrm{l}$ of $\mathrm{TH} \cdot \mathrm{HS}$ to $198 \mu \mathrm{l}$ of $\mathrm{BHI}$.

\section{H. RNA isolation}

RNA was isolated from $S$. sanguinis using a protocol developed for $S$. pneumoniae (84), with a few modifications. Briefly, JFP41 was grown in TH•HS until 
an $\mathrm{OD}_{660}$ of $0.068-0.074$ was obtained. Twenty $\mathrm{ml}$ of culture was removed from the inoculated broth and transferred to a tube of equal volume hot acid phenol containing $0.1 \mathrm{M}$ citrate buffer ( $\mathrm{pH} 4.3$, Sigma) and $0.1 \%(\mathrm{v} / \mathrm{v})$ sodium dodecyl sulfate (SDS, Ambion). The rest of the culture was exposed to CSP at a final concentration of 220ng $\mathrm{ml}^{-1}$ before also being transferred to hot acid phenol tubes. These tubes were then incubated in boiling water for $10 \mathrm{~min}$ and mixed intermittently. The samples were then cooled in an ice bath and transferred to Phase Lock Gel ${ }^{\mathrm{TM}}$ (PLG) tubes (5 Prime). After centrifugation at $1500 \mathrm{xg}$ for $5 \mathrm{~min}$, the supernatant was extracted using an equal volume of acid phenol:chloroform (1:1). The samples were then thoroughly vortexed and transferred to PLG tubes for an additional spin at $1500 \mathrm{xg}$ for $5 \mathrm{~min}$. The supernatant was once again extracted using an equal volume of chloroform, mixed, and centrifuged in PLG tubes. The supernatant was then adjusted to $0.3 \mathrm{M} \mathrm{NaOAc}$ using a 3 M stock (Ambion), and an equal volume of isopropanol was added. The sample was chilled for $20 \mathrm{~min}$ in an ice bath and centrifuged at $8000 \mathrm{x}$ g for $15 \mathrm{~min}$ at $10^{\circ} \mathrm{C}$. The resulting RNA pellet was washed with $70 \%$ ethanol, dried via tube inversion, and dissolved in $100 \mu 1$ DEPC-treated water.

These samples were then treated with DNase I and purified over RNeasy columns (Qiagen) according to protocols supplied by the manufacturer. Total yield was determined by examining absorbance at $260 \mathrm{~nm}$. Any samples with a 260/280 ratio $>2.2$ or $<1.8$ were discarded. In order to confirm good RNA quality, the remaining samples were run on an Experion ${ }^{\mathrm{TM}}$ Chip (BioRad) per manufacturer's protocol. Only RNA that 
was shown to maintain a $23 \mathrm{~S} / 16 \mathrm{~S}$ ratio $>1.8$ was kept and stored at $-80^{\circ} \mathrm{C}$ until further use.

\section{Streptococcus sanguinis DNA microarray slides}

Microarray slides for S. sanguinis were obtained from the J. Craig Venter Institute (JCVI), Pathogen Functional Genomics Resource Center (PFGRC). Unique oligonucleotides 70 bases in length were designed to represent internal regions of all 2274 ORFs predicted from the genome sequence of S. sanguinis (113). These probes were printed on $25 \times 75 \mathrm{~mm}$ aminosilane coated glass slides and then baked for $2 \mathrm{~h}$ at $80^{\circ} \mathrm{C}$ before DNA was cross-linked to the surface via UV exposure. All slides were stored at room temperature in a dessicator until use. For this study, oligonucleotides were printed in 96 grids containing 96 spots each. All genes had four technical replicates on the slide. As a control, each slide contained 500 Arabidopsis thaliana probes 70 bases in length.

\section{J. cDNA synthesis and labeling}

The protocol was taken from PFGRC and can be seen on their website at http://pfgrc.jcvi.org/index.php/microarray/protocols.html. Briefly, $2 \mu \mathrm{g}$ total RNA was thawed on ice and annealed to $6 \mu \mathrm{g}$ Random Hexamers (Invitrogen) in a total volume of $18.5 \mu \mathrm{l}$ and incubated at $70^{\circ} \mathrm{C}$ for $10 \mathrm{~min}$. The tubes were then snap frozen on ice before the addition of $6 \mu 1$ of $5 x$ First Strand Buffer (250 mM Tris-Cl, pH 8.3, $375 \mathrm{mM} \mathrm{KCl,} 15$ $\mathrm{mM} \mathrm{MgCl}_{2}$ ), $3 \mu 10.1 \mathrm{M}$ DTT (Invitrogen), and $0.6 \mu 1$ of a dNTP solution (25 mM each dATP, dCTP, and dGTP, $15 \mathrm{mM}$ dTTP (Invitrogen) and $10 \mathrm{mM}$ amino allyl-dUTP 
(Sigma)). A total of $400 \mathrm{U}$ of SuperScript III (200 $\mathrm{U}^{-1}$, Invitrogen) was added to the mixture and then incubated $\mathrm{O} / \mathrm{N}$ at $42^{\circ} \mathrm{C}$.

The RNA template was then hydrolyzed via the addition of $10 \mu 10.5 \mathrm{M}$ EDTA and $10 \mu 11 \mathrm{M} \mathrm{NaOH}$ and incubated at $65^{\circ} \mathrm{C}$ for $15 \mathrm{~min}$. The mixture was neutralized with $25 \mu 11 \mathrm{M}$ Tris pH 7.0 and $10 \mu 13 \mathrm{M} \mathrm{NaAc}$, and purified using MiniElute ${ }^{\circledR}$ PCR Purification Kit (Qiagen) replacing the Tris buffers with phosphate buffers (5 mM $\left.\mathrm{KPO}_{4}, \mathrm{pH} 8,80 \% \mathrm{EtOH}\right)$ and (4 $\left.\mathrm{mM} \mathrm{KPO}_{4}, \mathrm{pH} 8.5\right)$ for the wash and elution steps respectively. Samples were analyzed using a NanoDrop® Spectrophotometer where

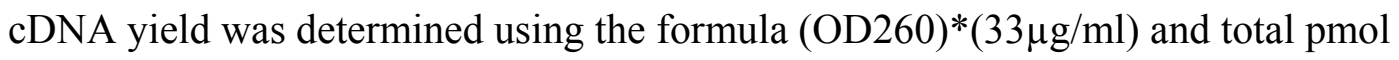
cDNA yield calculated using the following formula:

\section{(Total ng cDNA)*(1000 pg/ng)}

\section{$324.5 \mathrm{pg} / \mathrm{pmol}$}

The reaction was then dried in a Speed-Vac centrifuge before being resuspended in 4.5 $410.1 \mathrm{M} \mathrm{Na}_{2} \mathrm{HCO}_{3}, \mathrm{pH} 9.3$ and $4.5 \mu 1$ of the ester dye (Cy3 or Cy5 (Amersham) for the control and experimental samples respectively). The coupling reaction proceeded for $1.5-2 \mathrm{~h}$ at room temperature in the dark before being stopped via the addition of $35 \mu 1100 \mathrm{mM}$ NaAc pH 5.2 and then purified over Qiagen MiniElute PCR purification columns per manufacturer's protocol and supplied buffers. The cDNA probes were then analyzed using a NanoDrop ${ }^{\circledR}$ Spectrophotometer and pmol of dye incorporation determined using the general formula of $\left(\mathrm{A}^{*} \mathrm{e}\right) / \mathrm{b}$, where $\mathrm{A}$ is the absorbance at $550 \mathrm{~nm}$ 
or $650 \mathrm{~nm}$ (for Cy3 or Cy5 respectively); e is the extinction coefficient $(150,000$ liter/mol-cm and 250,000 liter/mol-cm, Cy3 and Cy5 respectively); and b is the path length in $\mathrm{cm}$. The nucleotide to dye incorporation ratio was ascertained via the following formula:

$$
\# \text { nucleotides/dye incorporated }=\frac{\text { pmol cDNA }}{\text { pmol CyDye }}
$$

Only samples with $>200$ pmol of dye incorporation and a nucleotide to dye incorporation ratio $<40$ were kept. The probes were then combined and dried to completion once again.

\section{K. Microarray hybridization}

Slides were pretreated for $2-3 \mathrm{~h}$ at $42^{\circ} \mathrm{C}$ in $50 \mu \mathrm{l}$ of prehybridization solution (5x SSC, $0.1 \%$ SDS, $1 \%$ BSA). Slides were maintained in hybridization cassettes (ArrayIt ${ }^{\circledR}$ ) throughout the incubation phase. The slides were then washed three times with MilliQ water in a High Throughput Wash Station (ArrayIt ${ }^{\circledR}$ ) followed with one wash in isopropanol and dried using a mini-slide centrifuge (Labnet International).

Dried probes were then resuspended in $50 \mu 1$ hybridization buffer $(40 \%$ formamide, 5x SSC, 0.1\% SDS, $0.6 \mu \mathrm{g} \mu \mathrm{l}^{-1}$ salmon sperm DNA). The solution was heated at $95^{\circ} \mathrm{C}$ for $10 \mathrm{~min}$ while vortexing intermittently and then transferred onto pretreated slides under a LifterSlip ${ }^{\mathrm{TM}}$ (Erie Scientific). The probes were allowed to hybridize for $16-20 \mathrm{~h}$ at $42^{\circ} \mathrm{C}$ in a hybridization cassette. Humidity was maintained 
with the addition of $15 \mu 1$ of unused hybridization buffer in each well. Slides were washed twice in $2 \mathrm{x} \mathrm{SSC,} 0.1 \% \mathrm{SDS}, 0.1 \mathrm{mM}$ DTT set at $55^{\circ} \mathrm{C}$ for $10 \mathrm{~min}$, twice in $0.1 \mathrm{x}$ SSC, $0.1 \%$ SDS, $0.1 \mathrm{mM}$ DTT for $5 \mathrm{~min}$, and twice in $0.1 \mathrm{x}$ SSC, $0.1 \mathrm{mM}$ DTT for 5 min. The last two washes were performed at room temperature. The slides were then dipped in MilliQ water before being dried in a mini-slide centrifuge. Microarrays were immediately scanned in an Axon GenePix ${ }^{\circledR} 4200$ scanner (MDS Analytical Technologies).

\section{Array analysis}

Data was collected and analyzed using GenePix Pro 6.0. In order to identify spots and determine normalization values, annotation information for the microarray slides was obtained from the J. Craig Venter Institute which allows a grid to be drawn around each array element. Each spot on the array was individually checked and flagged if it contained one of the following problems: low level of hybridization where the intensity of the signal was not $>$ two-fold of the local background level; high background streaks due to poor handling of the array that run into the spot; or if $>25 \%$ of the element contained poor hybridization where signal was undetectable. Once all values were collected, they were submitted to the Ramhorn Array Database (RAD) at http://ramhorn.csbc.vcu.edu/ilat/, created by Dr. Paul Fawcett at the Virginia Commonwealth University, which is essentially similar to the Stanford Array Database http://genome-www5.stanford.edu/. RAD stores images as well as the raw and normalized data from microarray experiments and provides a user-friendly method of visualizing and analyzing data. 
Once in RAD, the spots were filtered out based on three user-defined parameters. Firstly, the regression correlation for each spot had to be greater than 0.5 . Secondly, the mean of the red channel (experimental values) normalized to the green channel (control values) had to be 2 -fold greater than the normalized median values of the background for the red channel. Lastly, the mean values of the green channel had to be 2 -fold greater than the median values of the background. This allows a more unbiased method of filtering out elements that passed through the initial user-based filtering process as described above. In order to determine the significance of each element on the array, the Significance Analysis of Microarray (SAM) method was applied for each gene passing through the filtering process. SAM, originally developed by Tusher et al. (107), is a method by which genes are identified based on statistically significant changes in expression. This is performed by incorporating a set of gene specific $t$-tests and then assigning them a score on the basis of change in gene expression relative to the standard deviation of repeated measurements for that gene. Genes with scores greater than a user-defined threshold are deemed potentially significant. SAM also predicts the false discovery rate (FDR), or false positives, by analyzing permutations for each repeated measurement and estimating the percentages of genes discovered by chance. For this study, a threshold was used so that the FDR was $<0.1$.

Once genes with significant changes in expression were identified for each time point, the data were analyzed using Cluster 3.0 (22). This program performs a variety of clustering methods including hierarchical gene clustering. Once the data set was 
analyzed and genes clustered according to similar expression patterns, the data were visualized using TreeView. Both programs were developed and maintained by the Eisen $\mathrm{Lab}(22)$ at the University of California at Berkeley and can be downloaded from their website at http://rana.lbl.gov/eisen/?page $\mathrm{id}=42$.

\section{Array validation using real-time PCR}

All stored RNA samples were subjected to an additional DNAse treatment using TURBO DNA-free (Ambion) and purified per manufacturer's protocol. PCR amplification was performed using primers developed by Primer 3.0 and run on a $1.4 \%$ agarose gel to determine the presence of contaminating DNA. Afterwards, cDNA templates were created via Ready-To-Go ${ }^{\mathrm{TM}}$ You-Prime First-Strand Beads (Amersham Biosciences) as described in the manufacturer's protocol, using $2 \mu \mathrm{g}$ of total RNA. qRTPCR reactions were carried out in a 7500 Fast RT-PCR system (Applied Biosystems) using RT $^{2}$ Real-Time ${ }^{\mathrm{TM}}$ SYBR Green/Rox PCR master mix (SuperArray) and designed primers. Genes selected for qRT-PCR verification were comD, comE, comX, comYD, comEA, and gapA. For normalization values, tuf was used as a control. A list of primers used for this study is shown in Table 3. Data was collected for experimental samples at each time point of the competence induction. The experiment was conducted three times in triplicate. A standard curve was generated using a template of known concentration via serial dilutions. Normalized values were obtained and relative expression levels were determined by comparing mean quantity transcript levels to the control. 
Table 3. Primers used for qRT-PCR verification of microarray results 
Table 3

\begin{tabular}{|c|c|c|c|}
\hline Primer Name & Sequence $\left(5^{\prime}-3^{\prime}\right)$ & Target & Product Size \\
\hline comD-FWD & CGAGAAAGAAGAGCGTTTGC & \multirow{2}{*}{ comD } & \multirow{2}{*}{$206 \mathrm{bp}$} \\
\hline comD-RVS & AATTTGCATCAGCCAAGACC & & \\
\hline comE-FWD & TCAAGTCAGGATGGAAACGAC & \multirow{2}{*}{ comE } & \multirow{2}{*}{$160 \mathrm{bp}$} \\
\hline comE-RVS & TTCCTCCССCTTAATGTCAA & & \\
\hline comYD-FWD & TACCAGGAGACGCAGAGGTT & \multirow{2}{*}{ comYD } & \multirow{2}{*}{$203 \mathrm{bp}$} \\
\hline comYD-RVS & ACTGTCCTGTCCTCCGTCTG & & \\
\hline comEA-FWD & CTGAGAGCAGGAGCGAGAGT & \multirow{2}{*}{ comEA } & \multirow{2}{*}{$245 \mathrm{bp}$} \\
\hline comEA-RVS & GCCTCTGTCGCCGTATTTAG & & \\
\hline comX-FWD_3 & CGCCAGCCTTATGAAGAAGT & \multirow{2}{*}{$\operatorname{com} X$} & \multirow{2}{*}{$91 \mathrm{bp}$} \\
\hline comX-RVS_3 & TCGCTTCTCTGAAGGCAACT & & \\
\hline gapA-FWD & GCTTTCCGTCGTATCCAAAA & \multirow{2}{*}{ gapA } & \multirow{2}{*}{$221 \mathrm{bp}$} \\
\hline gapA-RVS & ACACCGTCAGTAGCCCAGTC & & \\
\hline tuf-FWD & GCTTCAACTGACGGACCAAT & \multirow{2}{*}{ tuf } & \multirow{2}{*}{$181 \mathrm{bp}$} \\
\hline tuf-RVS & CGTCACCTGGGAAGTCGTAT & & \\
\hline
\end{tabular}




\section{RESULTS}

\section{A. Density-dependence of natural competence in SK36}

The purpose of this study is to characterize competence regulation in $S$. sanguinis strain SK36. Therefore, it was first necessary to determine the cell density at which the optimal level of competence occurs. As first described by Tomasz and Hotchkiss (104), S. pneumoniae exhibits a cell-density dependent increase and decay of competence which has not yet been fully elucidated in S. sanguinis. In order to determine the effect of cell density on competence in SK36, numerous transformation assays were conducted on cultures. Initially, O/N cultures were diluted 1:200 and then $330 \mu 1$ aliquots were withdrawn after varying periods of time. However, varying results were obtained possibly due to inconstant incubation temperatures and repeated exposure to $\mathrm{O}_{2}$ that resulted from repeated sampling of the same culture. Subsequent experiments were conducted in which serial dilutions were performed on $\mathrm{O} / \mathrm{N}$ cultures, and the diluted cultures were allowed to incubate for three hours prior to removing only one aliquot from each tube for transformation. All experiments were plated in triplicate.

Figure 4 shows the combined results of multiple experiments. There was a definitive overall rise and fall of competence in SK36 that is related to cell density. Transformation frequencies gradually increased as cell population increased. When the cell density reached approximately a $\log _{(10)}$ value of $6\left(\right.$ i.e. $1 \times 10^{6} \mathrm{CFU} \mathrm{ml}^{-1}$ ), competence quickly increased reaching a maximum frequency of $21 \%$. The results show that as cells reached a density of $6.5-6.6 \operatorname{logs}$, competence was at its optimal 
Figure 4. Graph depicting the transformation frequency of SK36 relative to cell density expressed as CFU/ml. Each colored line represents an individual experiment. 
Figure 4

Density Dependence of Comptence in SK36

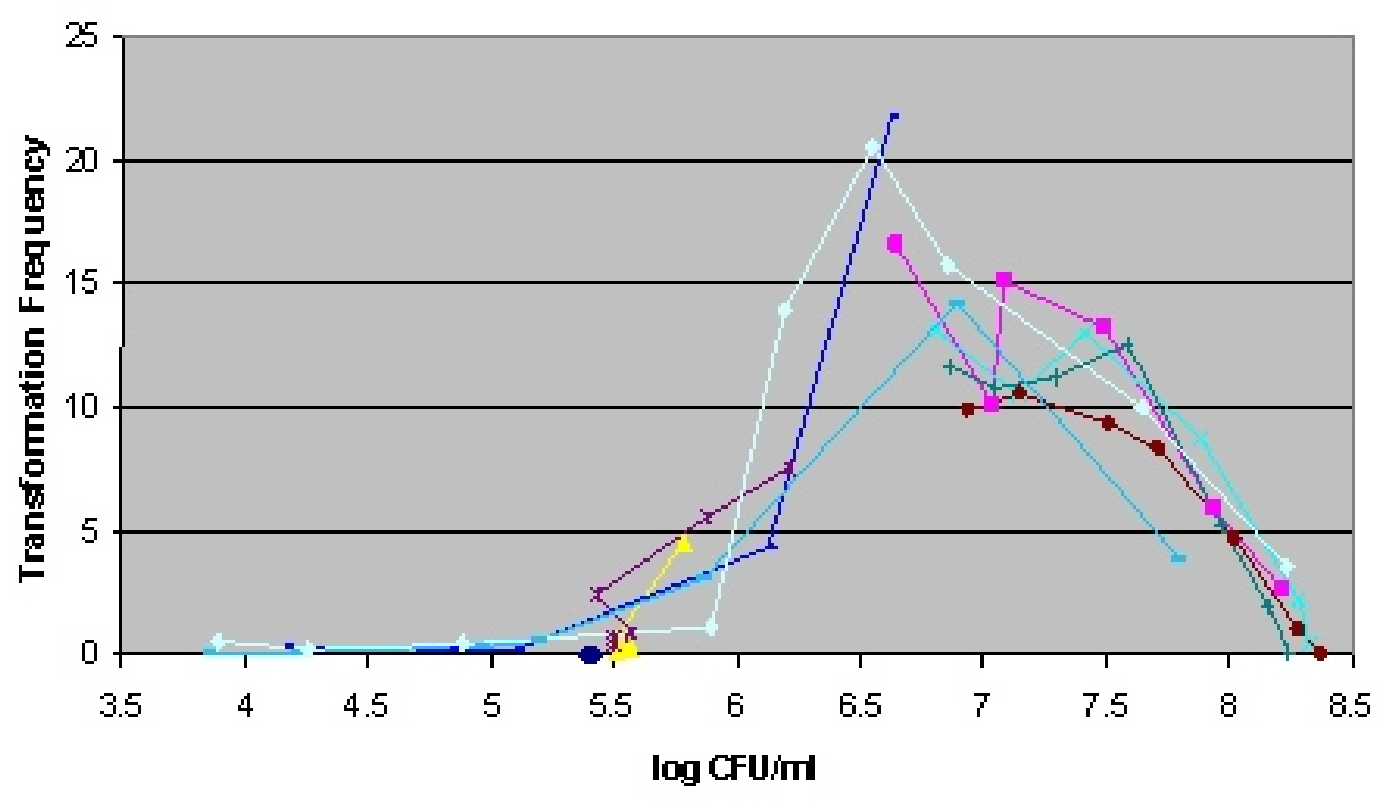


level. The cell density correlates to an absorbance value at $\mathrm{OD}_{660}$ of $0.068-0.074$. The results also showed that competence was specific at this cell density seeing that once frequency reached a peak, competence levels quickly dropped. As cell density approached $8.4 \operatorname{logs}$ (i.e. $2.7 \times 10^{8} \mathrm{CFU} \mathrm{ml}^{-1}$ ), competence decreased to below detection levels.

\section{B. SK36 competence and growth are negatively affected in acidic conditions}

In order to control natural induction of competence, investigators working with S. gordonii and S. pneumoniae have shown that competence may be inhibited by growing these species in acidic conditions with no adverse effects on growth $(84,108)$. However, no studies have been conducted on S. sanguinis to determine the effect of acidic conditions on competence and growth. To determine whether this is also seen in S. sanguinis, SK36 was grown $\mathrm{O} / \mathrm{N}$ in neutral $(\mathrm{pH} 7.6)$ and acidic $\mathrm{TH} \cdot \mathrm{HS}(8 \mathrm{mM} \mathrm{HCl}$, $\mathrm{pH}$ 6.8). The cultures were diluted 1:200 and a transformation assay was performed. As has been observed in other studies, transformation frequencies dropped to below detection levels suggesting that natural competence was effectively inhibited (Fig. 5A). It was observed, however, that $\mathrm{O} / \mathrm{N}$ cultures grown in acidic $\mathrm{TH} \cdot \mathrm{HS}$ had significantly lower $\mathrm{OD}_{660}$ readings than those grown in neutral conditions, which suggested a deleterious effect on the growth of SK36.

Acting on this observation, a growth study was performed in which $\mathrm{O} / \mathrm{N}$ cultures were grown in neutral conditions before being diluted 1:100 in acidic and neutral media. As suspected, growth was significantly affected $(\mathrm{p}<0.001)$ in a negative manner by growing in acidic conditions (Fig. 5B). When the experiment was performed again in 
Figure 5. Effects of acidic $\mathrm{pH}$ conditions on A) competence levels and B) growth rate in SK36. Error bars represent the standard deviation from the mean. 
Figure 5

A.

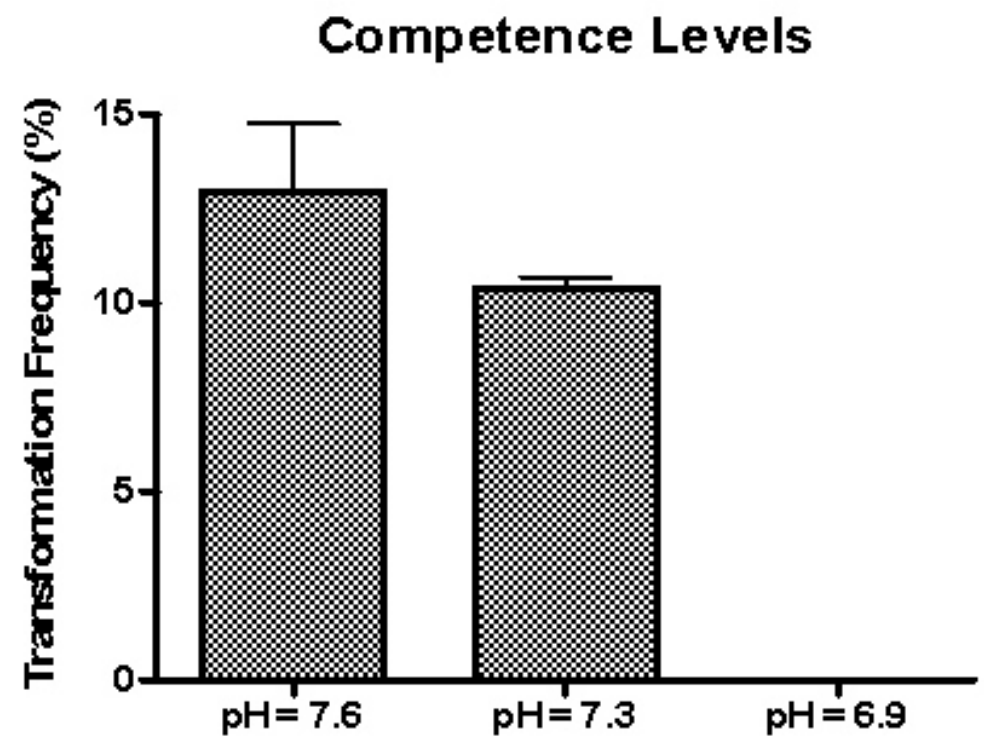

B.

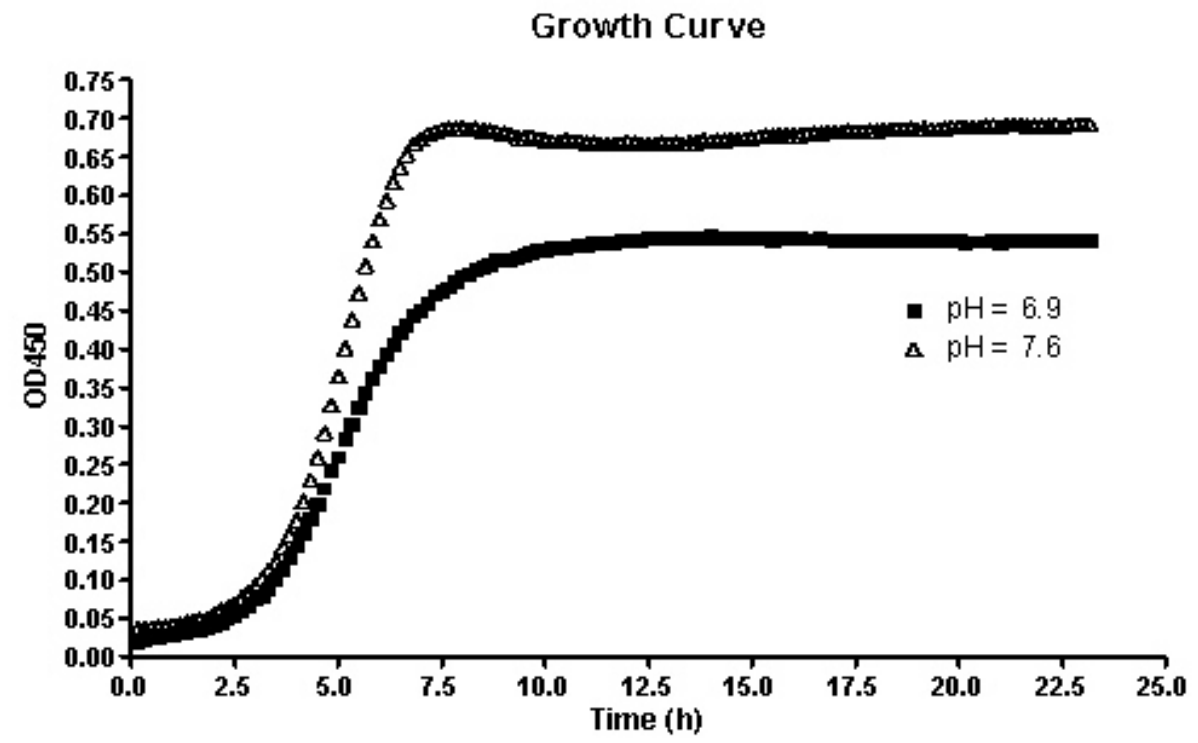


slightly more alkaline conditions, growth was only moderately affected (data not shown), however competence was partially restored (Fig 5A). The results were in stark contrast to what has been observed in other streptococcal species and presents a challenge for experimental design. Rather than repressing competence in SK36 via growth in acidic conditions, an alternate route was needed.

\section{Generation of a comC mutant}

In order to regulate competence in S. sanguinis without subjecting cultures to acidic conditions, $c 0 m C$ was targeted. The $\operatorname{com} C$ gene encoding competence stimulating peptide lies just downstream of $\operatorname{deg} P$ which is in the opposite orientation, as well as a hypothetical protein, SSA_2380, and a tRNA-Arg ${ }^{2}$ gene in the same orientation. The comC gene lies upstream of and is likely in the same operon as comDE. In order to ensure that the open reading frames for these downstream genes were maintained, primers were developed that would take the start codon of $\operatorname{com} C$ and fuse it with the $2^{\text {nd }}$ codon of comD. In so doing, comC would be deleted as well as the entire 29-bp intergenic region between $\mathrm{comC}$ and $\mathrm{comD}$. Thus, the comD gene would presumably be controlled using the transcriptional and translational start signals that normally control comC expression. A schematic representation of this work is shown in Figure 6.

After the first round of PCR amplification, two products were recovered. The upstream region was predicted to be approximately $1.9 \mathrm{~kb}$ in length while the downstream product was approximately $1.0 \mathrm{~kb}$. Both products were compared to a molecular weight standard and confirmed to be the correct size (Fig 7A). Afterwards, the products were purified and then combined using outer primers in a second round of 
Figure 6. Flow chart depicting the construction of JFP41, a mutant deficient in the production of endogenous CSP due to a $\operatorname{comC}$ knockout. 
Figure 6

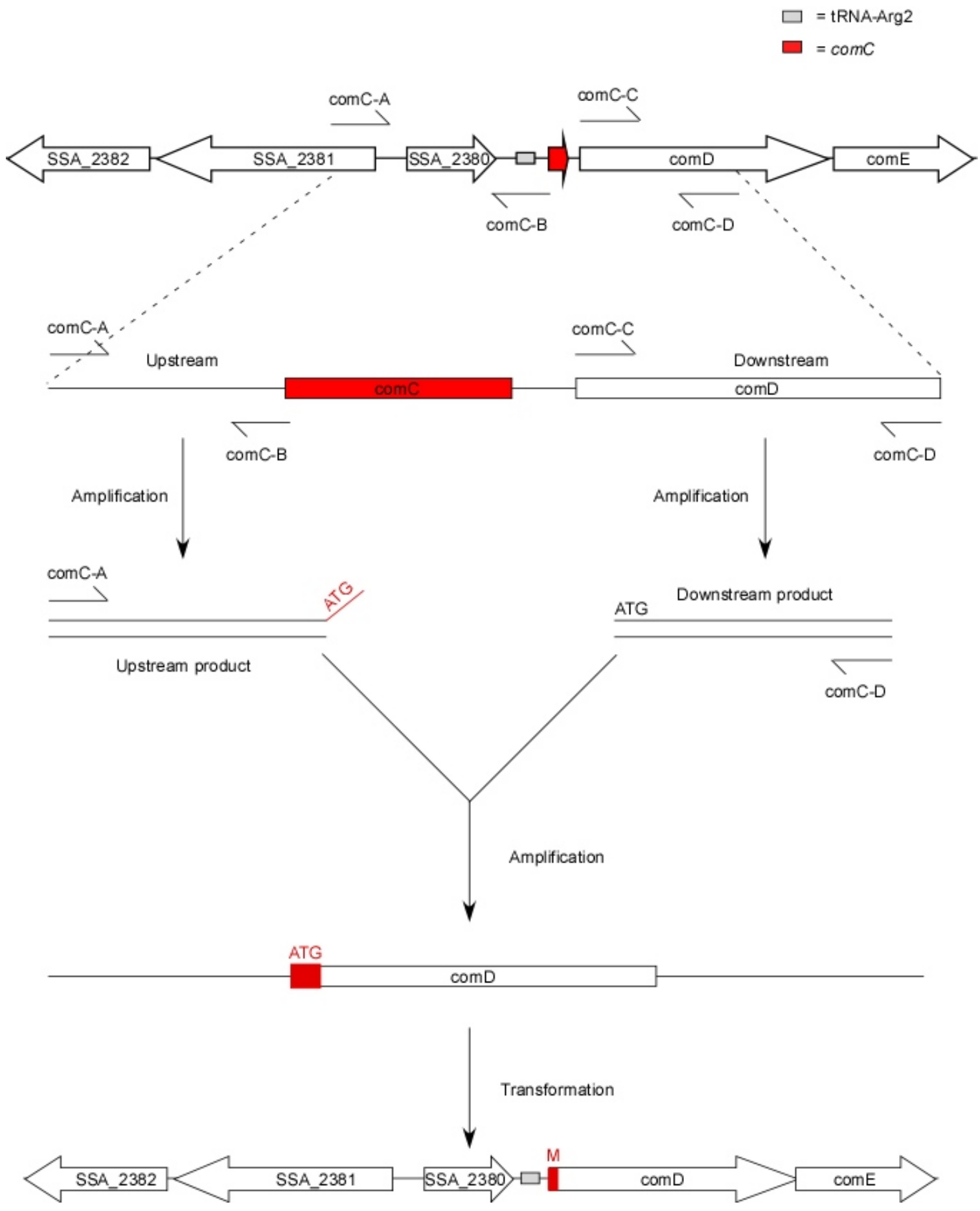


Figure 7. The images show the results obtained after PCR amplification. A) This gel shows the results after the first round of amplification. The upstream product is shown in lane 4 and 5. The downstream product is shown in lane 6 and 7. B) This image shows the results after a successful gene SOEing experiment. Lanes 3-6 show the final product in varying concentrations. 
Figure 7

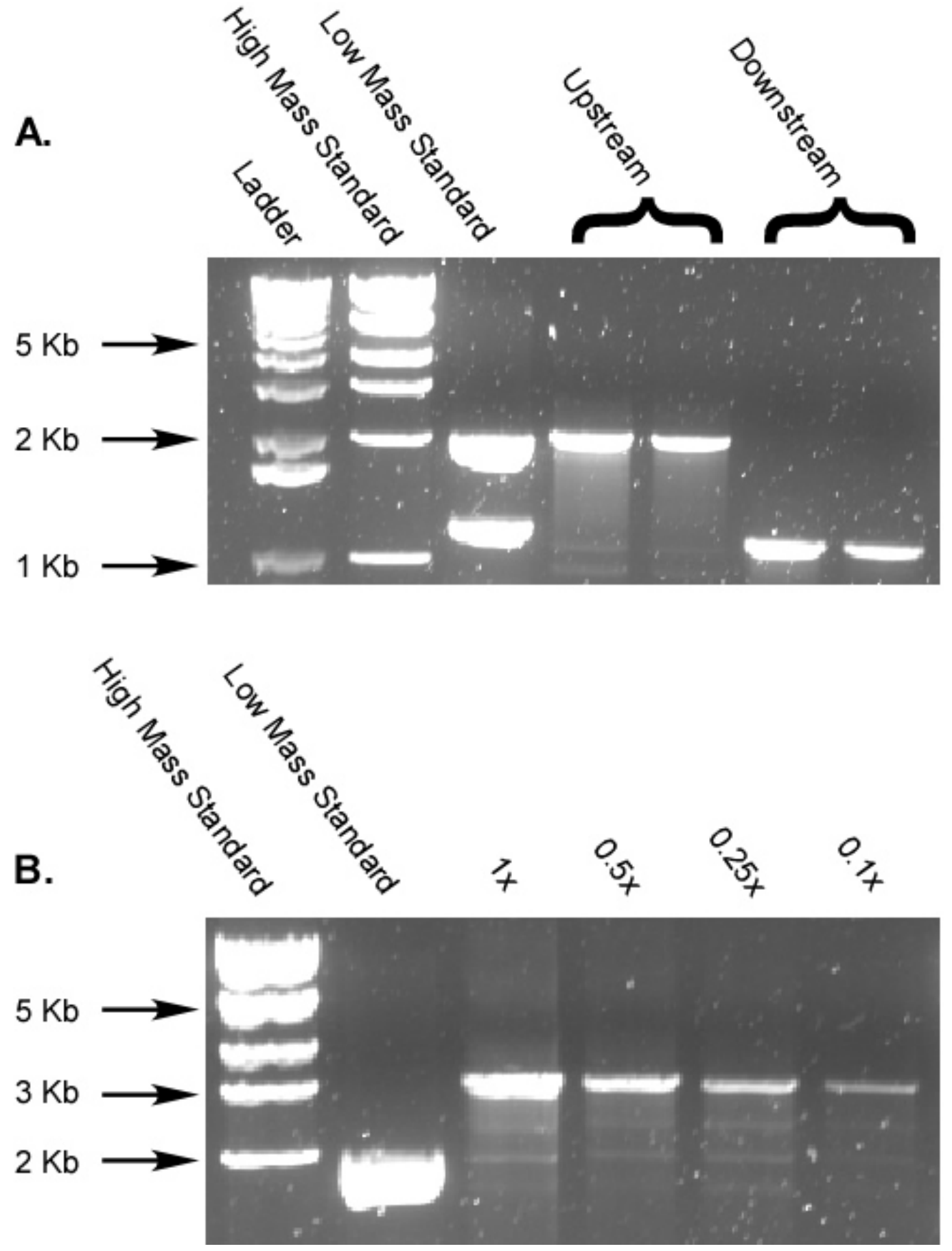


PCR amplification. The resulting $3 \mathrm{~kb}$ product was diluted and run on a gel (Fig. 7B). The image shows four bands at different concentrations which were all compared to mass standards to determine concentrations. They were also compared to a molecular weight standard to confirm the correct size of the final product.

Having attained the correct sized amplicon, the purified product was then introduced into SK36 by transformation, as described in Materials and Methods. Transformed cells were surface-plated on BHI and incubated for 48 hours at $6 \% \mathrm{O}_{2}$. Having no selectable marker for these mutants, PCR-screening was conducted on 80 selected colonies. Primers were developed that flanked comC such that the difference between SK36 and mutant products was predicted to be $135 \mathrm{bp}$. Figure 8A shows the results of the first 20 of 80 colonies examined during the first round of screening. As can be seen, all colonies gave rise to amplicons of the size predicted for the wild-type gene. A more careful inspection revealed that colony number 13 contained what would appear to be a light band of the size expected for the mutant strain (indicated by a white arrow). Since this sample also had a wild-type size band, it was hypothesized that the initial colony selected was a mixture of mutant and wild-type cells.

In order to prove this and subsequently retrieve pure colonies, colony number 13 was re-streaked on BHI plates and grown for 48 hours at $37^{\circ} \mathrm{C}$ in $6 \% \mathrm{O}_{2}$. A total of 40 colonies were selected and once again screened using the selected primers. This time, single bands were obtained (Fig. 8B) confirming the earlier suspicion that the colony was mixed. Out of these 40 colonies, 8 were positive for the mutant strain and 3 colonies were arbitrarily selected and designated JFP41-1, JFP41-2, and JFP41-3. 
Figure 8. Images show the results of the mutant selection based on PCR-screening. In both pictures, the control "WT" and "Mut" lane contain the amplicon recovered after PCR amplification using SK36 gDNA and the purified product attained from gene SOEing respectively. A) The agarose gel showing that colony number 13 contains an amplicon of the size predicted for the mutant. B) After re-streaking colony number 13 and PCR-screening, 8 colonies (four in this image) were shown to yield bands equivalent in size to that expected for the mutant strain. 
Figure 8

A.

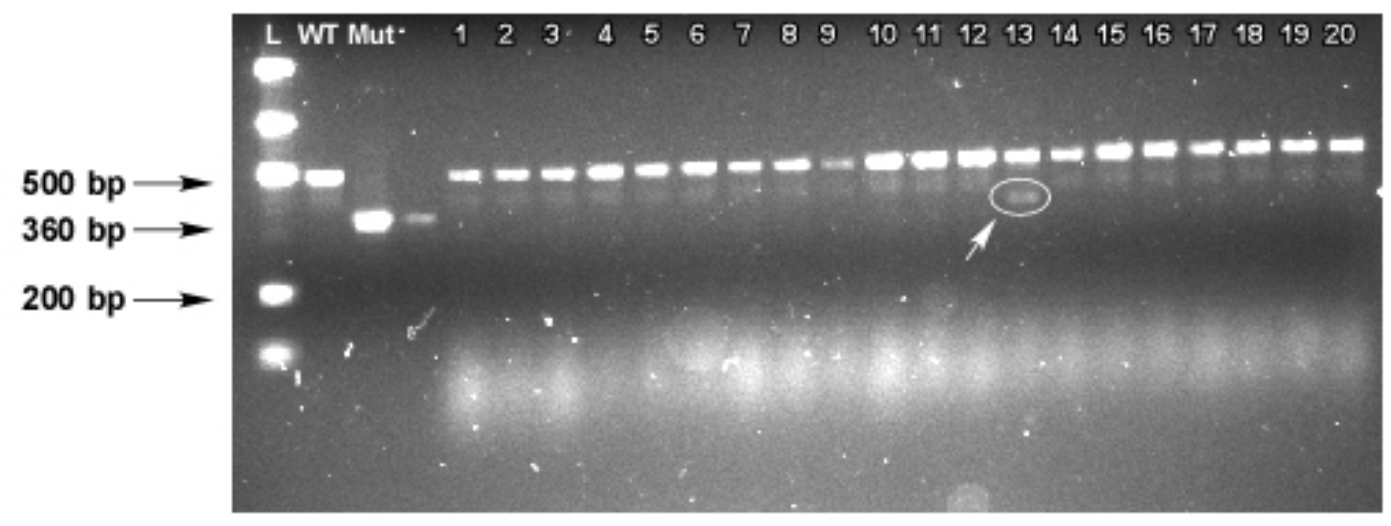

B.

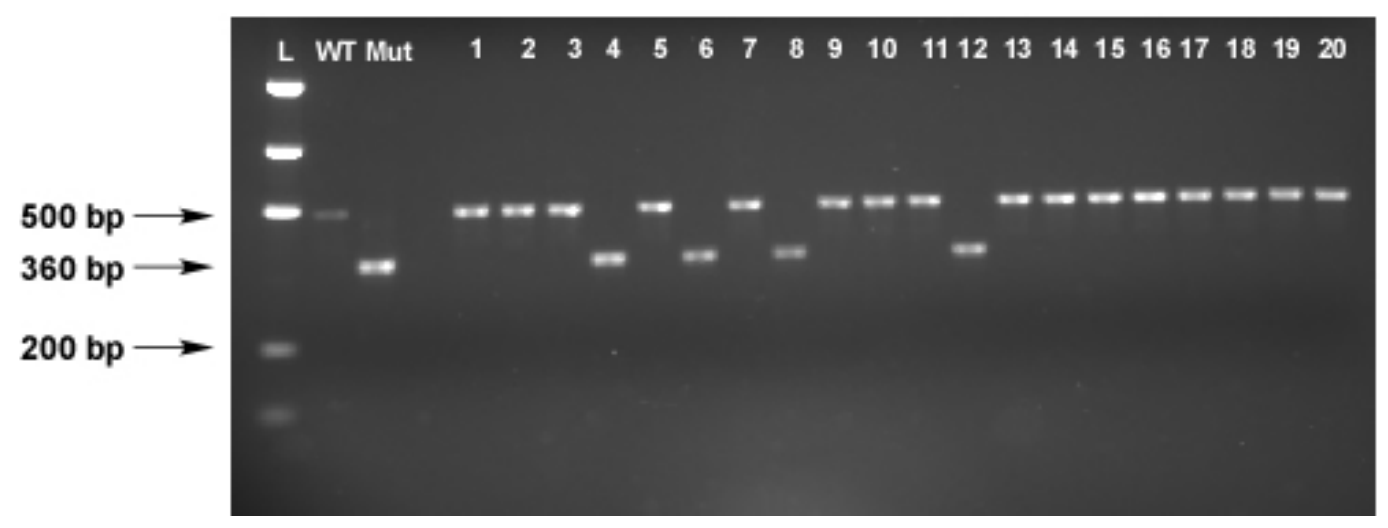


Since comC was deleted in the mutant strain, it was expected that it would lack the ability to become naturally competent, but would regain competence to SK36 levels via the addition of exogenous CSP. In order to confirm this hypothesis, the three selected colonies were once again streaked on BHI plates, and one colony from each plate was taken. A transformation study was conducted on these isolated colonies where they were first grown to an $\mathrm{OD}_{660}$ of 0.074 and then transformed using pJFP36 $\pm 70 \mathrm{ng}$ of exogenous CSP. pJFP36 is a suicide plasmid containing approximately 650-bp of DNA on either side of an erythromycin (Em) resistance cassette that must integrate into the chromosome to confer Em resistance (see Materials and Methods). The cells were incubated for $1.5 \mathrm{~h}$ before being diluted into 96-well plates and left $\mathrm{O} / \mathrm{N}$ to incubate at $37^{\circ} \mathrm{C}$.

When grown in normal conditions in the absence of exogenous CSP and antibiotics, all three mutants grew at a slightly faster rate than SK36, although all strains reached stationary phase approximately $7.5 \mathrm{~h}$ after dilution (Fig. 9A). When the mutant strains were grown in BHI in the presence of Em and absence of CSP, all three strains lacked any sign of growth in the media (Fig. 9B). Meanwhile, SK36 displayed a small lag before reaching stationary phase approximately $17 \mathrm{~h}$ after dilution. This was expected considering that all cells not transformed would have been killed upon contact with the antibiotic. Lastly, when the mutant strains were treated with CSP and then grown in the presence of Em, all strains grew at the same rate as SK36 (Fig. 9C), reaching stationary phase approximately $15 \mathrm{~h}$ after initial dilution. 
Figure 9. Transformation study analysis of the three putative mutants compared to SK36. A) Growth of the 4 strains in BHI. B) Cells not pretreated with CSP during transformation assays and grown in BHI and Erm $\left(10 \mu \mathrm{g} \mathrm{ml}^{-1}\right)$. C) Cells pretreated with CSP during the transformation assay and grown in BHI and Erm $\left(10 \mu \mathrm{g} \mathrm{ml}^{-1}\right)$. 
Figure 9

\section{A. Growth Curve in BHI}

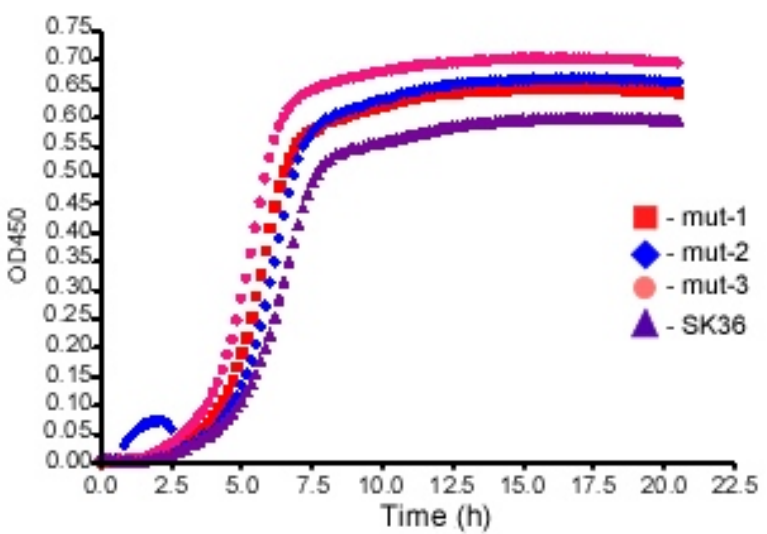

\section{B. Growth Curve in BHI+Abx}

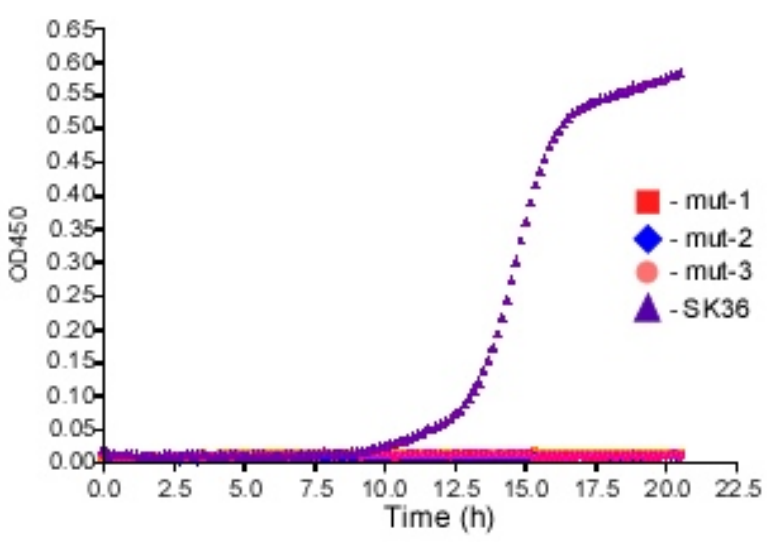

\section{Growth Curve in BHI + Abx, CSP}

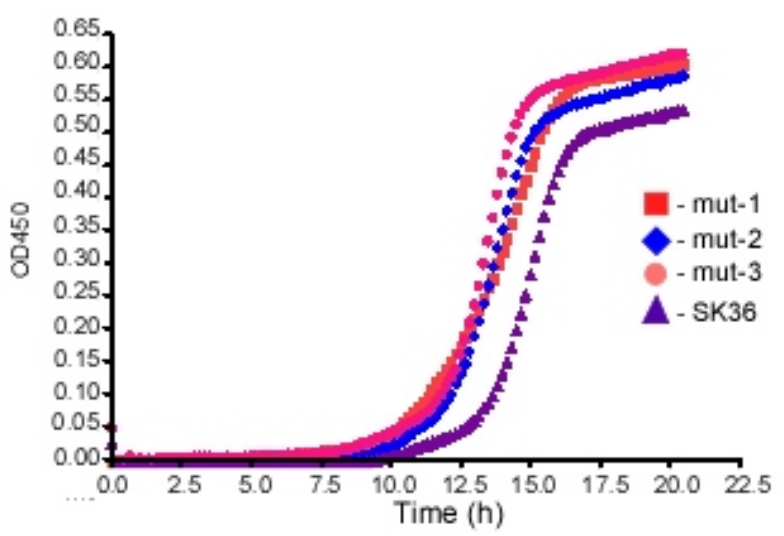


The results demonstrate two critical factors required for the expected mutant phenotype: first, that natural competence was abolished; and secondly, that competence was restored upon the addition of exogenous CSP. The three selected mutants displayed both characteristics. In order to definitively confirm the phenotype of these mutants, a transformation assay was conducted on JFP41-1 - which will hereinafter be referred to as simply JFP41 - and compared to SK36. Transformation frequency levels obtained from this experiment show that natural competence in JFP41 was below detection levels. However, when the cells were treated with CSP, competence was restored to near SK36 levels (Fig. 10).

Lastly, having confirmed the identity of this mutant, the final analysis was to confirm that the DNA sequence of the mutant had the expected sequence. This was important to determine for future analysis using JFP41. Primers were designed to obtain sequence information that spanned the entire $3-\mathrm{kb}$ region introduced by transformation, paying particular attention to the junction point. A schematic representation of the "strategy view" generated by Seqman ${ }^{\mathrm{TM}}$ II is shown in Figure 11. Using these primers, it was confirmed that JFP41 contained no mutations anywhere within the span of DNA introduced into the cell during mutagenesis. Thus, we concluded that a comC mutant had been successfully created.

\section{Determination of the optimal concentration of CSP for JFP41 competence}

Once a comC mutant was generated, it was critical to characterize its specific phenotype and behavior in order to further study gene regulation. To do so, it was first necessary to determine the amount of exogenous CSP required in order to induce 
Figure 10. Competence levels of WT and JFP41 in standard transformation assays. The graph is the result of one experiment plated in triplicate. The error bars represent the standard deviation from the mean. 
Figure 10

\section{Competence Levels}

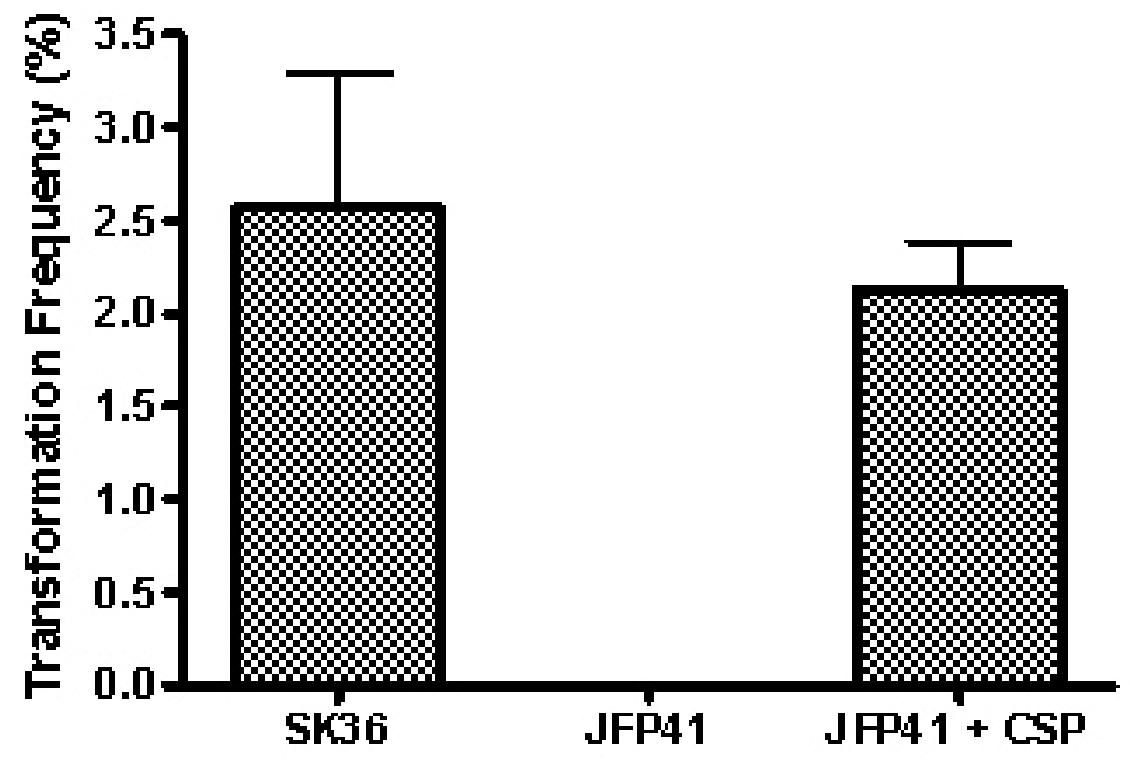


Figure 11. A strategy view obtained by Seqman depicting the location of the selected primers as well as the overall length of product obtained via sequencing. 
Figure 11

$\square$ - tRNAArg2

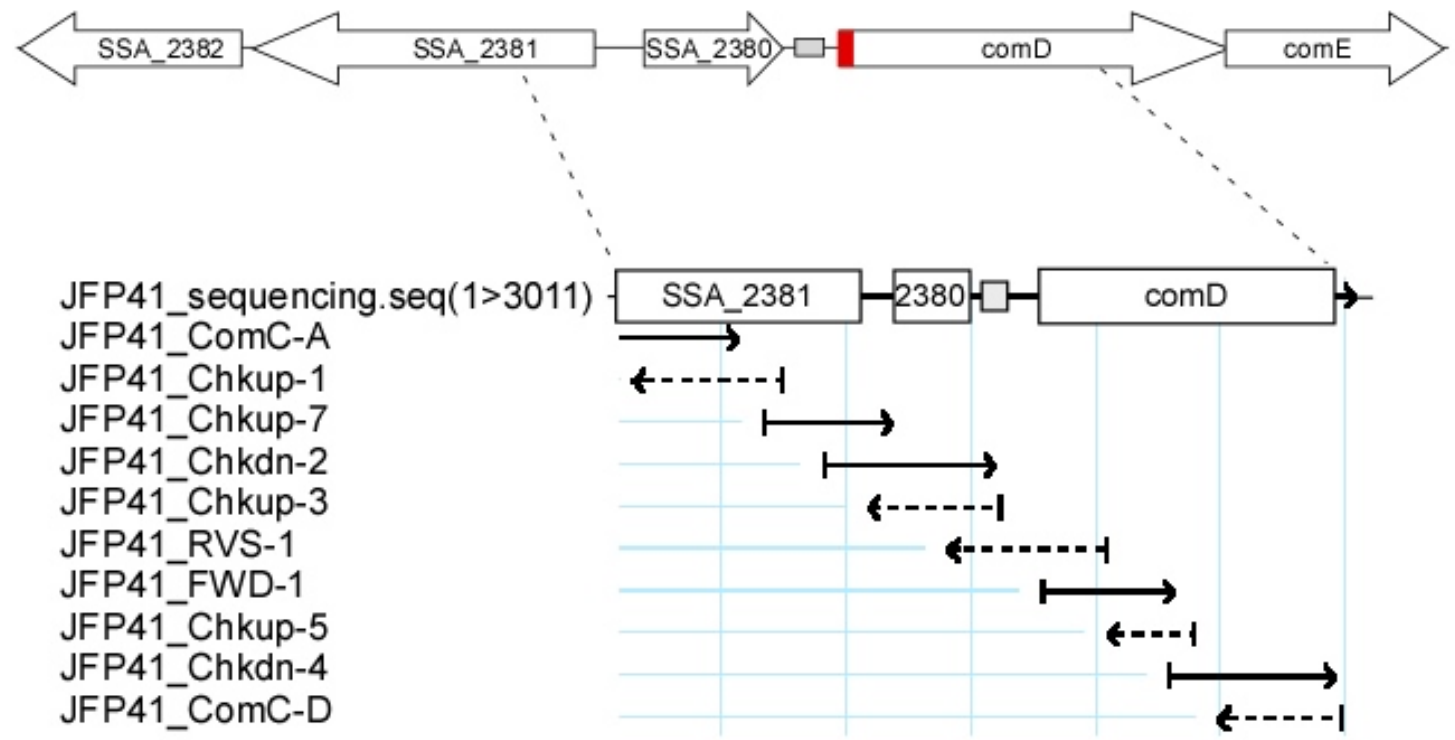


optimal competence in the mutant. For this study, JFP41 was transformed with pJFP16 and treated with varying concentrations of CSP. Plasmid pJFP16 contains approximately 950 bp of DNA homologous to $n r d D$ flanking a chloramphenicol $(\mathrm{Cm})$ resistance cassette which must be integrated into the chromosome to confer $\mathrm{Cm}$ resistance. Figure 12 shows the results of three separate experiments plated in triplicate. Results showed that there was an initial linear response to CSP concentration and transformation frequency. However, once the cells were treated with CSP at a concentration approximately $200-240 \mathrm{ng} \mathrm{ml}^{-1}$, competence peaked. Once the concentration of CSP rose to 300ng $\mathrm{ml}^{-1}$ and above, competence began to depreciate, although transformants were still recovered. The results showed that JFP41 can be induced to optimal competence levels via the addition of exogenous CSP at a concentration of approximately $200-240 \mathrm{ng} \mathrm{ml}^{-1}$. Previous studies have used 70ng of CSP in $334 \mu \mathrm{l}$ of culture. This is equivalent to $210 \mathrm{ng} \mathrm{ml}^{-1}$ which falls within the range observed here.

\section{E. Density dependence of competence in JFP41}

Natural competence within the cell rose and fell with respect to cell density in the wild-type strain, SK36 (see Fig. 4). This fits the model established for $S$. pneumoniae (104) in which density dependence of competence results from accumulation of CSP. It was therefore of interest to determine whether in strain JFP41, which produces no CSP, competence could be induced at any cell density upon addition of exogenous CSP. To test this hypothesis, a study was performed similarly to the SK36 experiment described previously (See section A) in which $\mathrm{O} / \mathrm{N}$ cultures were serially 
Figure 12. The effect of exogenous CSP concentration on the transformation frequency of the comC mutant. The results shown are the average of three individual experiments plated in triplicate. Error bars represent the standard deviation in transformation frequencies between the three experiments. 
Figure 12

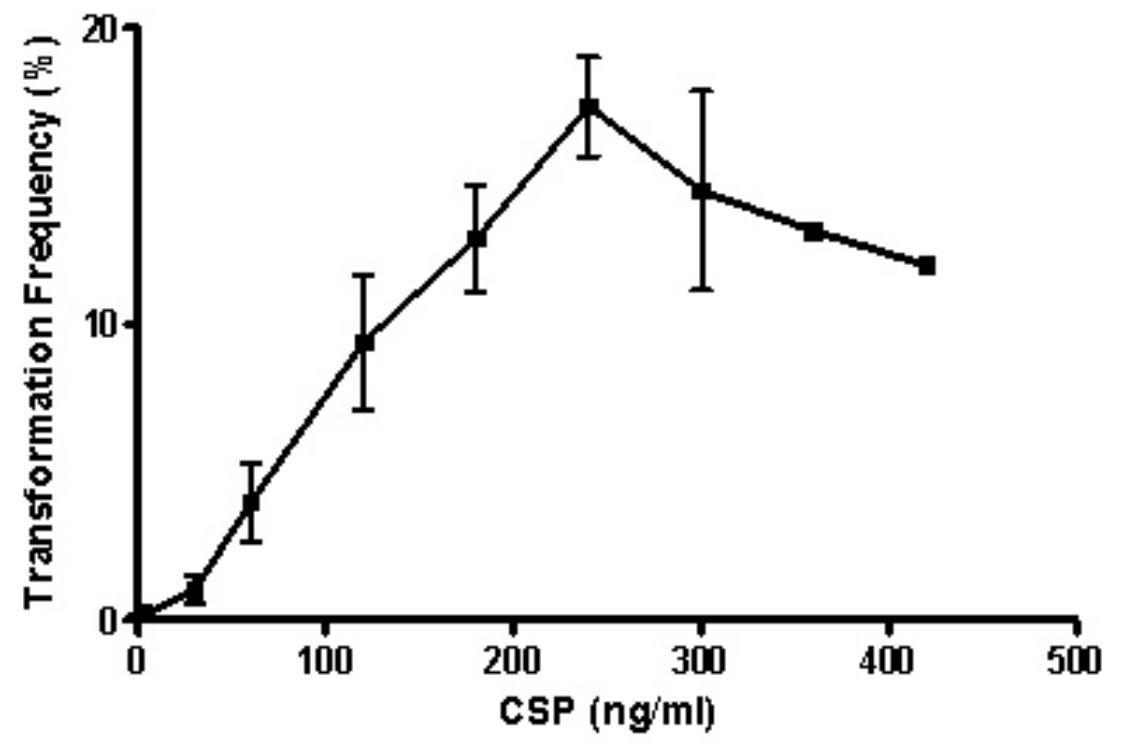


diluted and allowed to incubate for $3 \mathrm{~h}$ before treatment with CSP (210 $\left.\mathrm{ng} \mathrm{m}^{-1}\right)$ and transforming DNA. Colonies were counted 48 hours after layer plating.

Interestingly, three individual experiments yielded two unique trends (Fig. 13). The first series (blue line) showed that transformation frequency levels rose and fell with respect to cell density. As cells reached a $\log _{(10)}$ value of 7.2 (i.e. a cell density of $\sim$ $1.6 \times 10^{7} \mathrm{CFU} / \mathrm{ml}$ ) an optimal competence level was reached. The other two series showed a different trend. In both cases, transformation frequencies were at their highest when cell density was quite low. As cell density decreased, the number of transformants recovered began to drop. These two seemingly different trends did converge at one point, however. As cell density approached approximately a $\log _{(10)}$ value of $8.8(6.3 \mathrm{x}$ $10^{8} \mathrm{CFU} \mathrm{ml} \mathrm{m}^{-1}$ ), competence had dropped yielding a transformation frequency less than $4 \%$.

With such different trends observed in this study, it was difficult to conclude whether or not cell density truly had any effect on the ability of JFP41 to become competent. Whereas in one experiment low cell density produced very low numbers of transformants, another two studies yielded opposite results. In all three cases, competence dropped significantly at $>1 \times 10^{8} \mathrm{CFU} \mathrm{ml}^{-1}$; yet even these numbers were significantly higher than what was observed in SK36, where competence had dropped to below detection levels. The results suggest that the density dependence of competence is not due entirely to CSP accumulation. Therefore, when using JFP41 with exogenous CSP to model natural competence in a wild-type strain, it was concluded that 
Figure 13. Graph depicting the transformation frequency of JFP41 relative to cell density expressed as CFU/ml. Each colored line represents an individual experiment. 
Figure 13

Density dependence of competence in JFP41

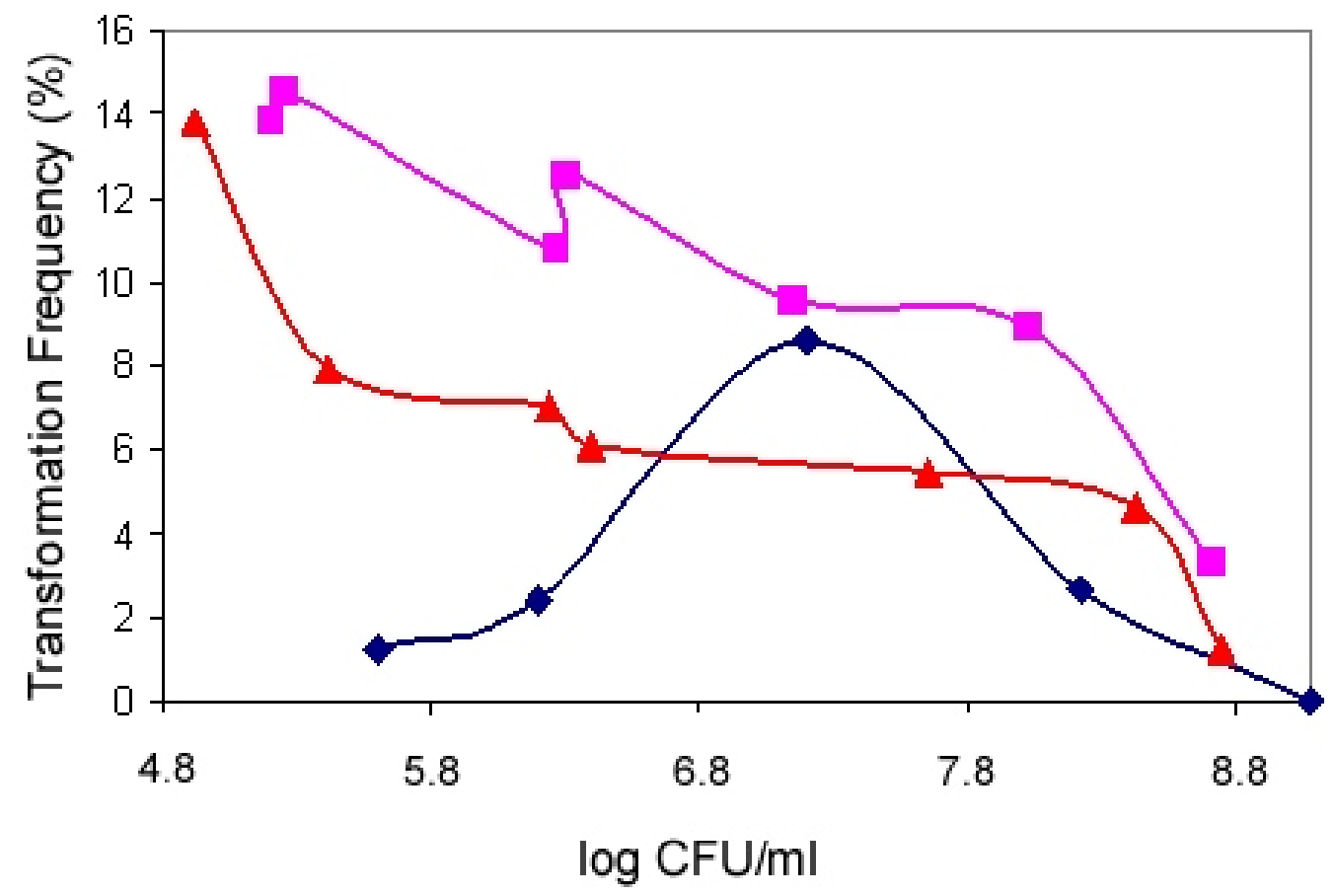


it would be best to use cell densities similar to those at which competence occurs naturally in the wild-type strain. Further investigations characterizing the cell density dependence of competence in the comC mutant should be conducted in future studies.

\section{F. Decay of competence after CSP treatment in JFP41}

Previous studies have shown that upon the addition of the competence stimulating peptide to cells, S. gordonii quickly becomes competent. However, after a short period, competence decays, most likely due to gene repression (108). To determine whether this would also be true for S. sanguinis, the duration of competence after exposure to CSP was examined in JFP41. For this experiment, JFP41 was pretreated with CSP for the length of time indicated and then allowed to incubate with transforming DNA for 10 minutes before being layer plated. As in previous experiments in which layer plating was used, the cells were allowed to incubate for $2 \mathrm{~h}$ to allow expression of the antibiotic resistance and then an additional layer $\pm \mathrm{Cm}$ was added. The results showed a clear response to CSP (Fig. 14). After 10 minutes of incubation, JFP41 reached maximum competence levels comparable to those that had been observed previously in SK36. After 20 minutes, competence began to drop, and by 30 minutes, transformation frequency had decreased to $5 \%$.

This rise and fall of competence recorded here is similar to that found in $S$. gordonii (108), indicating a strong temporal regulation of competence. Interestingly, while in the former study competence dropped to below detection levels, competence in this study showed observable transformants well above the limit of detection at a transformation frequency $<5.8 \times 10^{-6} \%$. It should be noted that the level of detection in 
Figure 14. Activation and repression of competence in JFP41 after induction with CSP. The results are the product of three individual biological replicates plated in triplicate. The error bars shown here represent the standard deviation from the average transformation frequencies between each experiment. 
Figure 14

Temporal Reponse to CSP In JFP41

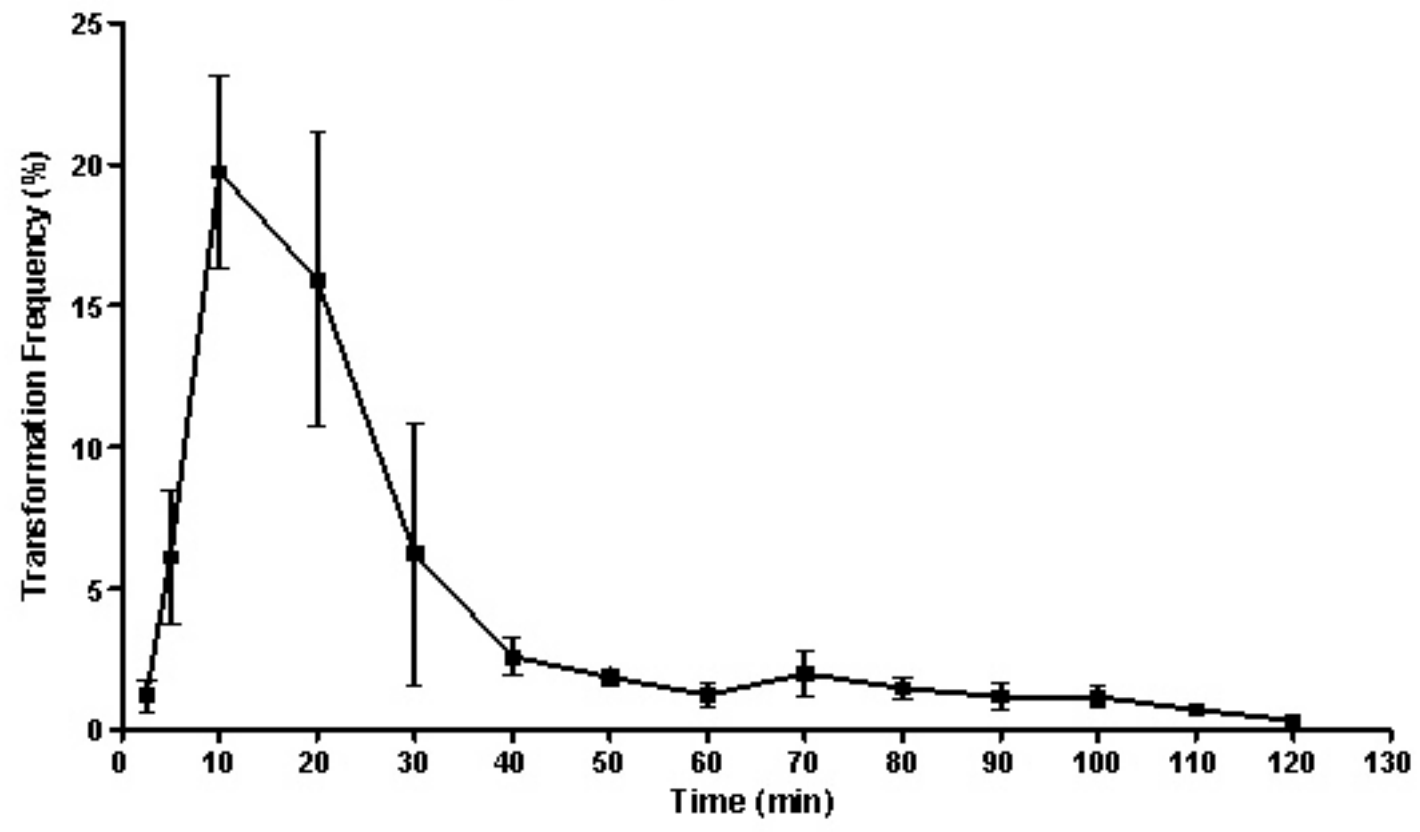


the former study was similar to this study at $<5 \times 10^{-6} \%$. This may indicate that competence in the $S$. sanguinis mutant may not be fully repressed once activated by CSP. However, considering that there is a definitive rise and fall of competence, it may be concluded that temporal expression of competence is indeed occurring in the mutant. Once induced in the cell, the duration of competence is about 30 minutes based on these results. Therefore, any examination of gene expression during induction of competence should be performed within 30 minutes of CSP addition.

\section{G. Microarray analysis of transcriptional regulation in response to CSP.}

Based on the results described above, transcription of the regulatory genes activated upon competence induction was analyzed via microarray analysis based on a 30-minute time period. Since genes responsible for the regulation of competence are upregulated and down-regulated rather quickly, it was concluded that the analysis would be performed at 2.5 minute intervals, and since mRNA levels can vary greatly in such short intervals, it was determined that RNA would be isolated by a hot acid phenol protocol whereby cells are lysed immediately upon exposure to phenol and boiled in a water bath. Cells were grown to an $\mathrm{OD}_{660}$ of $0.068-0.074$ before being induced to competence via the addition of exogenous CSP at 220ng $\mathrm{ml}^{-1}$. Twenty-ml aliquots were removed and used for RNA extractions. The quality of the purified RNA was determined by checking the 23S / 16S rRNA ratio using an Experion ${ }^{\mathrm{TM}}$ Chip (see Materials and Methods). Figure 15 demonstrates one such analysis. Degraded or contaminated RNA samples were easily discovered and discarded. 
Figure 15. An image created with the Experion ${ }^{\mathrm{TM}}$ software looking at the quality of prepared RNA. The ladder is observed in the first lane. The second lane is an example of an acceptable RNA sample, showing very little degradation. 23S rRNA is observed at the top, $16 \mathrm{~S}$ rRNA is the second band, and $5 \mathrm{~S}$ rRNA is the bottom band. The third lane shows an example of degraded RNA. RNA degradation was estimated by taking the density of the $23 \mathrm{~S}$ band and dividing it by the density of the $16 \mathrm{~S}$ band. 
Figure 15

\section{Experion analys is of two RNA samples}

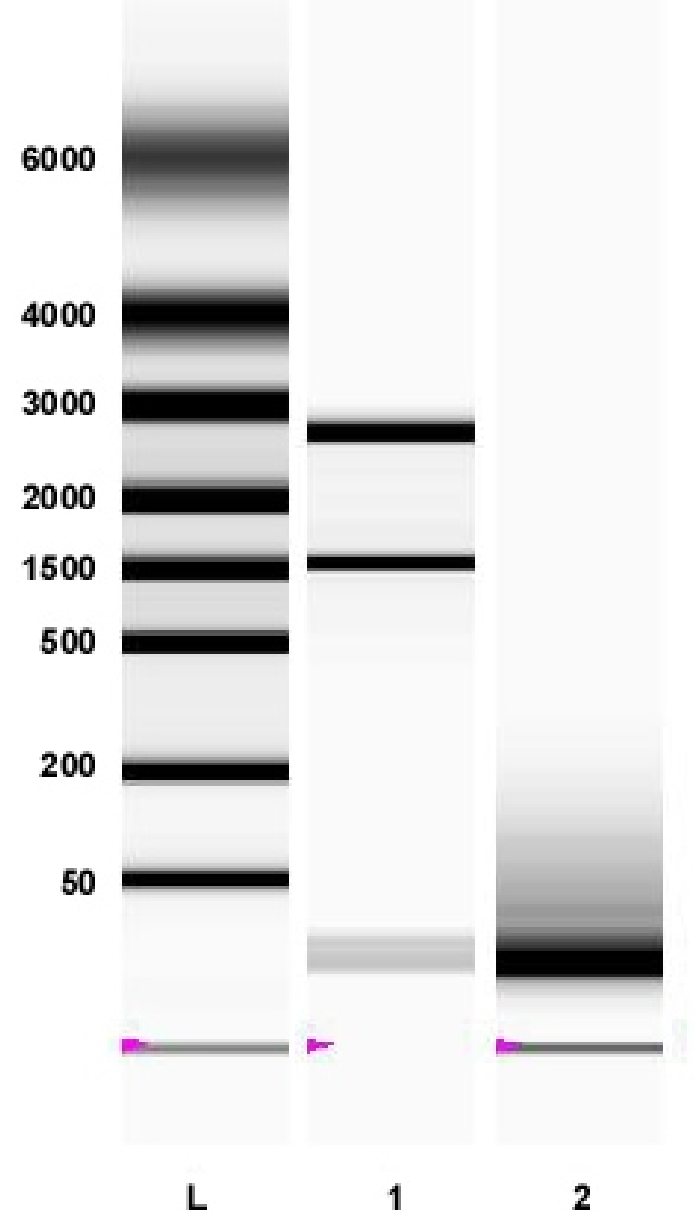


A cDNA library was prepared using isolated RNA samples and then hybridized to microarrays slides constructed by JCVI containing unique oligonucleotides specific for each predicted ORF in SK36. During initial analysis, each spot on the array was individually checked and flagged if it contained one of the following problems: low level of hybridization where the intensity of the signal was $<$ two-fold of the local background level; high background streaks that run into the spot due to poor handling of the array; or if $>25 \%$ of the element contained poor hybridization where signal was undetectable. Examples of each condition are shown in Figure 16. Data was collected from microarrays and submitted and filtered out based on significance using SAM. For this study, a two-class unpaired response format was conducted to calculate values for each gene. SAM was allowed up to 1000 permutations and missing data was imputed based on the K-nearest neighbor method. The delta value of significance was also adjusted so that the False Discovery Rate calculated by SAM was $<0.1$ attaining qvalues of $0 \%$. Candidate genes were identified if after exposure to CSP there was a greater than twofold increase in expression relative to expression at the 0 min time point (no CSP addition). Table 4 below shows the normalized values obtained by taking the $\log _{(2)}$ of the ratio of the value of the samples induced to competence via CSP, to the values of the uninduced samples. Out of 208 genes that made it through the cut-off point of greater than twofold regulation, 128 genes were found to be up-regulated. Out of this pool, only five genes appeared to be regulated greater than 16-fold at 2.5 minutes compared to base levels: comD, comE, comX, SSA_0195, and SSA_1889. For 
Figure 16. Examples showing the reasons for flagging and consequently removing microarray spot from being used in the normalization of values. Spots which A) show low levels of hybridization, B) that have high background streaks running through them, or C) do not contain enough data to confidently calculate values. 
Figure 16

A.

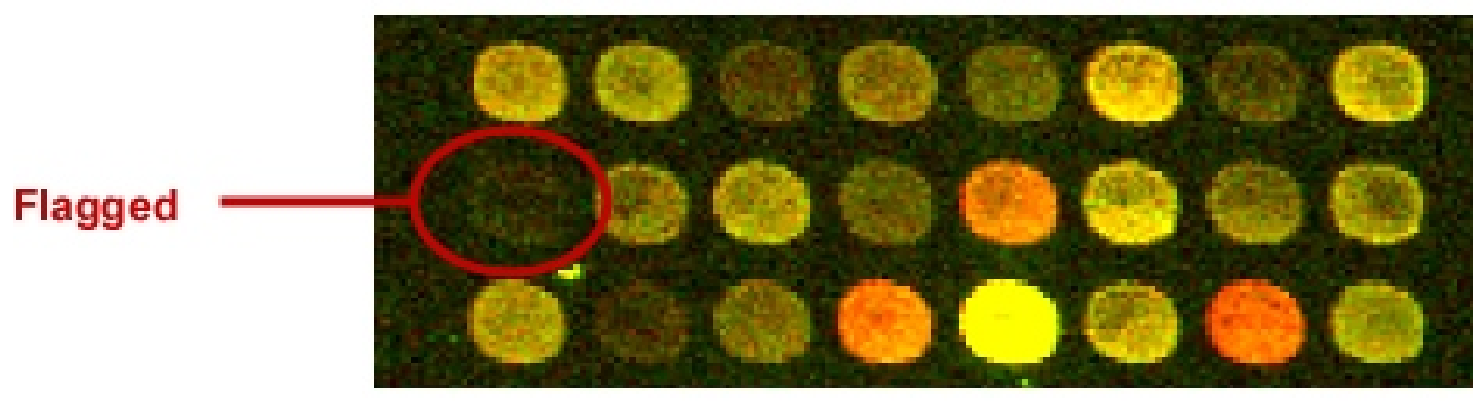

B.

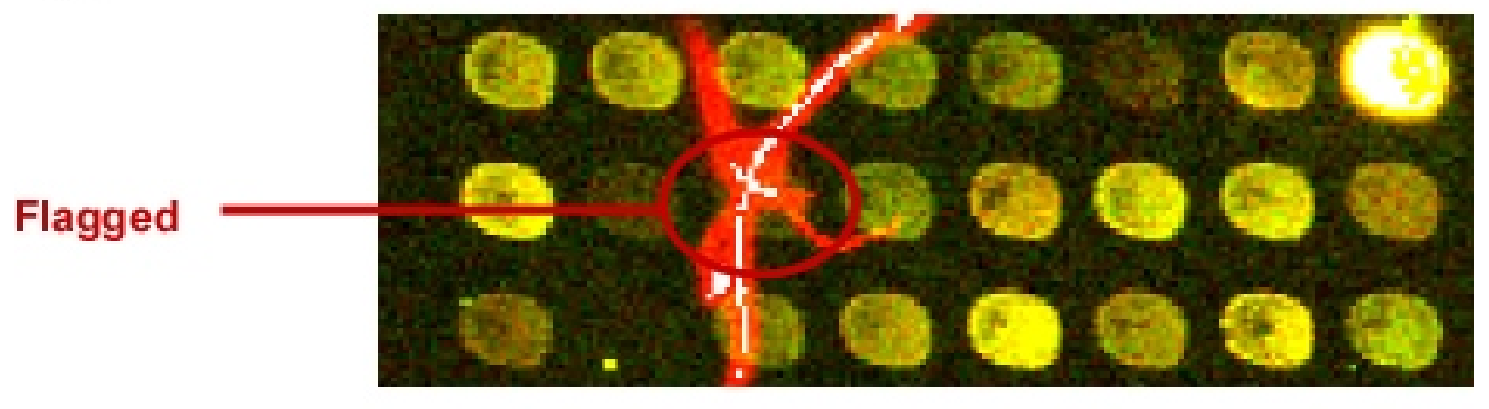

c.

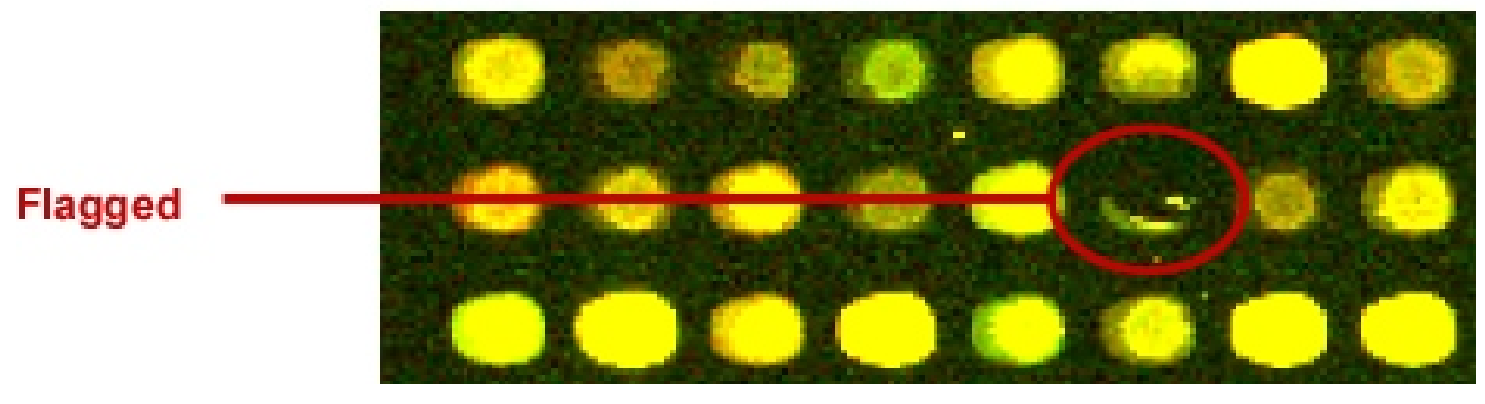


Table 4. All genes listed were found to be significantly expressed by SAM and were up-regulated a minimum of twofold relative to base levels in at least one time point. The values listed here have been normalized to the control (uninduced) and represent the result of taking the log base two of their initial values. Original values were taken by dividing the median average intensity of the experimental value by the median average intensity of the control. Blank values are due to insufficient data. 
Table 4

\begin{tabular}{|c|c|c|c|c|c|c|c|c|c|c|c|c|}
\hline${ }^{a}$ locus & $\begin{array}{c}{ }^{b} \text { Gene } \\
\text { Symbol }\end{array}$ & $\begin{array}{c}{ }^{\circ} 0 \mathrm{~min} \\
\text { Average }\end{array}$ & $\begin{array}{c}2.5 \mathrm{~min} \\
\text { Average }\end{array}$ & $\begin{array}{c}5 \mathrm{~min} \\
\text { Average }\end{array}$ & $\begin{array}{c}7.5 \mathrm{~min} \\
\text { Average }\end{array}$ & $\begin{array}{c}10 \mathrm{~min} \\
\text { Average }\end{array}$ & $\begin{array}{l}12.5 \mathrm{~min} \\
\text { Average }\end{array}$ & $\begin{array}{c}15 \text { min } \\
\text { Average }\end{array}$ & $\begin{array}{l}17.5 \text { min } \\
\text { Average }\end{array}$ & $\begin{array}{c}20 \mathrm{~min} \\
\text { Average }\end{array}$ & $\begin{array}{c}30 \mathrm{~min} \\
\text { Average }\end{array}$ & $\begin{array}{c}{ }^{\mathrm{e}} \text { Gene } \\
\text { Direction }\end{array}$ \\
\hline SSA_0016 & $\operatorname{com} X$ & 0.09 & 4.63 & 6.36 & 5.21 & 5.19 & 4.40 & 2.98 & & 2.55 & 1.84 & + \\
\hline SSA_0023 & aspc & -0.05 & -0.03 & -0.37 & -0.20 & 0.44 & 0.89 & 1.07 & 0.90 & 0.85 & 0.25 & + \\
\hline SSA_0025 & reco & 0.03 & -0.12 & -0.24 & -0.22 & 0.60 & 0.80 & 1.19 & 1.25 & 0.76 & 0.14 & + \\
\hline SSA_0036 & & 0.03 & 0.41 & 6.23 & 5.20 & 6.16 & 5.88 & 5.88 & 5.20 & 5.28 & 4.23 & - \\
\hline SSA_0063 & ruvB & 0.05 & 0.04 & 0.08 & 1.09 & 1.39 & 1.19 & 1.30 & 1.22 & 1.53 & 0.72 & + \\
\hline SSA_0141 & & 0.41 & -0.28 & 0.48 & 1.17 & 1.60 & -0.25 & -0.14 & 0.67 & -0.11 & 0.12 & + \\
\hline SSA_0166 & & 0.75 & -0.27 & 0.62 & 2.67 & 2.88 & 1.44 & 1.09 & 0.93 & 1.33 & 1.64 & + \\
\hline SSA_0185 & comYB & -0.57 & 0.29 & 5.98 & 5.24 & 6.38 & 6.04 & 6.07 & 4.28 & 5.11 & 5.08 & + \\
\hline SSA_0186 & comYC & 0.15 & 1.02 & 6.09 & 4.93 & 5.60 & 5.70 & 6.07 & 4.72 & 5.56 & 4.59 & + \\
\hline SSA_0187 & comYD & -0.36 & 1.13 & 6.38 & 5.58 & 6.34 & 6.39 & 6.03 & 5.01 & 5.83 & 5.01 & + \\
\hline SSA_0188 & & & 1.23 & 6.24 & 5.89 & 6.69 & 6.47 & 6.31 & 5.16 & 5.89 & 5.59 & + \\
\hline SSA_0189 & & -0.13 & 0.37 & 6.44 & 6.06 & 6.60 & 6.21 & 6.30 & 5.40 & 6.02 & 5.00 & + \\
\hline SSA_0190 & & -0.14 & 0.33 & 5.58 & 5.40 & 6.08 & 5.94 & 5.94 & 5.40 & 5.63 & 4.76 & + \\
\hline SSA_0191 & & -0.21 & -0.04 & 4.52 & 5.25 & 6.19 & 5.72 & 6.18 & 5.48 & 5.52 & 4.54 & + \\
\hline SSA_0192 & ackA & 0.11 & 0.21 & 3.10 & 3.19 & 4.50 & 3.93 & 4.43 & 4.16 & 3.98 & 3.25 & + \\
\hline SSA_0197 & folP & 0.36 & 1.60 & 2.50 & 2.17 & 1.69 & 1.28 & 0.79 & 0.92 & 0.87 & 0.74 & + \\
\hline SSA_0198 & & -0.02 & 1.19 & 2.33 & 1.67 & 1.47 & 1.03 & 0.96 & 0.89 & 0.70 & 0.72 & + \\
\hline SSA_0199 & folE & -0.02 & 1.06 & 2.24 & 2.00 & 1.41 & 1.00 & 0.69 & 0.59 & 0.50 & 0.60 & + \\
\hline SSA_0200 & folk & 0.09 & 0.77 & 2.14 & 1.23 & 0.86 & 1.16 & 0.83 & 0.56 & 0.52 & 0.64 & + \\
\hline SSA_0212 & & 0.23 & 0.15 & 0.05 & 1.01 & 1.45 & 0.36 & 0.19 & 0.25 & 0.14 & 0.49 & + \\
\hline SSA_0214 & ssb2 & & 0.94 & 6.13 & 6.09 & 6.74 & 7.06 & 6.70 & 5.47 & 6.14 & 4.32 & + \\
\hline SSA_0215 & rbsB & -0.19 & -0.15 & 0.85 & 1.68 & 2.36 & 2.33 & 2.16 & 1.67 & 1.42 & 0.85 & + \\
\hline SSA_0216 & & -0.10 & -0.32 & 0.72 & 1.57 & 2.14 & 2.18 & 2.19 & 1.70 & 1.14 & 0.61 & + \\
\hline SSA_0217 & & -0.26 & -0.38 & 0.25 & 1.54 & 2.00 & 2.06 & 1.85 & 1.48 & 1.17 & 0.67 & + \\
\hline SSA_0218 & & 0.23 & 0.17 & 0.49 & 1.09 & 1.70 & 2.23 & 2.01 & 1.64 & 1.38 & 1.18 & + \\
\hline SSA_0225 & gros & 0.24 & 0.10 & -0.10 & 0.30 & 0.52 & 1.04 & 0.88 & 0.47 & 0.32 & 0.53 & + \\
\hline SSA_0240 & & 0.20 & 0.40 & 0.43 & 1.55 & 1.07 & 1.03 & 0.63 & 0.37 & 0.93 & 0.05 & + \\
\hline SSA_0242 & & 0.04 & -0.28 & 0.58 & 1.67 & 1.12 & 0.70 & 0.16 & 0.29 & 0.14 & -0.04 & + \\
\hline SSA_0267 & & -0.33 & -0.29 & 0.35 & 1.27 & 0.15 & 0.23 & -0.11 & -0.20 & 0.17 & 0.56 & - \\
\hline SSA_0310 & & 1.03 & -0.24 & 2.55 & 3.97 & 3.10 & 3.18 & 1.86 & 1.35 & 2.43 & 2.20 & + \\
\hline SSA_0316 & & 0.52 & -0.23 & 0.41 & 1.51 & 1.37 & 0.94 & 0.87 & 1.25 & 1.11 & 0.52 & + \\
\hline
\end{tabular}




\begin{tabular}{|c|c|c|c|c|c|c|c|c|c|c|c|c|}
\hline${ }^{\mathrm{a}}$ locus & $\begin{array}{c}\text { bene } \\
\text { Symbol }\end{array}$ & $\begin{array}{c}\text { c0 min } \\
\text { Average }\end{array}$ & $\begin{array}{c}2.5 \mathrm{~min} \\
\text { Average }\end{array}$ & $\begin{array}{c}5 \mathrm{~min} \\
\text { Average }\end{array}$ & $\begin{array}{c}7.5 \mathrm{~min} \\
\text { Average }\end{array}$ & $\begin{array}{c}10 \mathrm{~min} \\
\text { Average }\end{array}$ & $\begin{array}{l}12.5 \mathrm{~min} \\
\text { Average }\end{array}$ & $\begin{array}{c}15 \text { min } \\
\text { Average }\end{array}$ & $\begin{array}{l}\text { d17.5 min } \\
\text { Average }\end{array}$ & $\begin{array}{c}20 \mathrm{~min} \\
\text { Average }\end{array}$ & $\begin{array}{c}30 \text { min } \\
\text { Average }\end{array}$ & $\begin{array}{c}{ }^{\mathrm{e}} \text { Gene } \\
\text { Direction }\end{array}$ \\
\hline SSA_0410 & & 0.08 & 0.07 & 0.84 & 1.59 & 1.46 & 1.18 & 1.45 & 0.44 & 0.93 & 0.64 & - \\
\hline SSA_0433 & & 0.15 & 0.13 & 0.39 & 1.55 & 2.00 & 0.94 & 0.85 & 0.91 & 1.03 & 0.73 & - \\
\hline SSA_0504 & amiF & -0.12 & 0.24 & 0.43 & 0.90 & 1.23 & 0.92 & 0.27 & 0.06 & 0.28 & 0.42 & + \\
\hline SSA_0563 & & -0.26 & -0.19 & 0.17 & 1.31 & 1.61 & 0.20 & 0.09 & 0.73 & 0.01 & 0.44 & - \\
\hline SSA_0589 & dapE & -0.38 & -0.30 & 0.13 & 0.79 & 1.21 & 0.67 & 0.28 & 0.69 & 0.40 & 0.16 & + \\
\hline SSA_0597 & & 0.15 & 0.23 & 0.74 & 0.68 & 0.52 & 0.17 & 0.53 & 1.03 & 0.09 & 0.35 & + \\
\hline SSA_0620 & & -0.18 & -0.19 & 0.08 & 1.22 & 1.88 & 1.01 & 0.89 & 0.82 & 0.57 & 0.34 & - \\
\hline $\begin{array}{l}\text { SSA_0639 } \\
\text { SSA_0640 } \\
\text { SSA_0642 }\end{array}$ & pilD & $\begin{array}{l}-0.26 \\
-0.24 \\
0.35\end{array}$ & $\begin{array}{l}0.67 \\
1.01 \\
2.22\end{array}$ & $\begin{array}{l}4.74 \\
5.17 \\
6.66\end{array}$ & $\begin{array}{l}5.93 \\
6.04 \\
6.34\end{array}$ & $\begin{array}{l}5.61 \\
5.66 \\
5.94\end{array}$ & $\begin{array}{l}5.22 \\
5.47 \\
6.05\end{array}$ & $\begin{array}{l}5.34 \\
5.34 \\
6.45\end{array}$ & $\begin{array}{l}4.80 \\
4.99 \\
5.55\end{array}$ & $\begin{array}{l}4.77 \\
4.93 \\
5.54\end{array}$ & $\begin{array}{l}2.91 \\
3.20 \\
3.44\end{array}$ & $\begin{array}{l}- \\
- \\
-\end{array}$ \\
\hline SSA_0675 & $x$ seB & -0.11 & 0.02 & 1.16 & 1.45 & 1.85 & 2.61 & 2.03 & 1.40 & 1.37 & 0.31 & + \\
\hline SSA_0676 & ispA & 0.45 & 0.09 & 1.69 & 2.48 & 3.02 & 3.25 & 2.63 & 2.34 & 1.55 & 0.97 & + \\
\hline SSA_0677 & hlyA & 0.13 & -0.04 & 1.58 & 2.81 & 3.13 & 3.30 & 3.04 & 2.22 & 2.02 & 0.84 & + \\
\hline SSA_0678 & ahrC & -0.14 & -0.07 & 1.38 & 3.07 & 3.31 & 3.15 & 3.01 & 2.41 & 1.91 & 0.87 & + \\
\hline SSA_0679 & recN & 0.16 & 0.31 & 1.51 & 2.33 & 3.17 & 3.54 & 3.16 & 2.54 & 2.01 & 1.31 & + \\
\hline SSA_0680 & pphA & 0.02 & 0.24 & 1.28 & 3.37 & 4.01 & 3.85 & 3.40 & 3.04 & 2.36 & 2.01 & + \\
\hline SSA_0715 & comEA & -0.01 & 1.51 & 6.01 & 5.65 & 6.41 & 5.98 & 6.55 & 5.45 & 5.57 & 4.03 & + \\
\hline SSA_0716 & comEC & -0.17 & & 5.93 & 5.69 & 6.64 & 5.73 & 5.95 & 5.33 & 6.00 & 5.19 & + \\
\hline SSA_0718 & & -0.18 & -0.01 & 0.73 & 1.21 & 1.61 & 0.77 & 1.08 & 0.54 & 0.70 & 0.76 & + \\
\hline SSA_0720 & holA & -0.09 & -0.05 & 0.13 & 1.00 & 0.85 & 1.36 & 1.07 & 0.51 & 0.55 & 0.27 & + \\
\hline SSA_0743 & $\arg R$ & -0.20 & -0.36 & 1.14 & 2.77 & 2.32 & 1.59 & 1.17 & 0.80 & 1.76 & 1.25 & - \\
\hline SSA_0749 & CoiA & & & 2.90 & & 3.35 & 3.50 & 2.51 & 2.31 & & & + \\
\hline SSA_0750 & & 0.17 & 0.22 & 2.23 & 1.89 & 2.43 & 3.47 & 2.23 & 2.17 & 1.37 & 0.51 & + \\
\hline SSA_0824 & dnaG & -0.17 & -0.14 & 0.83 & 2.06 & 2.70 & 2.51 & 2.15 & 1.83 & 1.39 & 0.67 & + \\
\hline SSA_0825 & rpoD & -0.28 & -0.25 & 0.92 & 2.23 & 2.99 & 2.37 & 2.00 & 1.71 & 1.32 & 0.47 & + \\
\hline SSA_0826 & & 0.29 & 0.25 & 1.22 & 2.36 & 3.06 & 3.08 & 2.64 & 2.10 & 1.61 & 0.94 & + \\
\hline SSA_0981 & leuD & -0.13 & -0.46 & -0.22 & 0.12 & 1.41 & 0.44 & 0.37 & 0.81 & 0.57 & 0.41 & + \\
\hline SSA_1000 & galR & -0.24 & -0.47 & -0.16 & 1.00 & 1.00 & 0.21 & 0.08 & 0.56 & 0.47 & 0.55 & - \\
\hline SSA_1009 & galT & -0.01 & 0.59 & 0.77 & 0.24 & 0.62 & -0.04 & 0.39 & 1.04 & -0.10 & 0.32 & + \\
\hline SSA_1076 & & 0.15 & 0.07 & 0.13 & 0.97 & 1.04 & 0.26 & 0.18 & 0.41 & 0.37 & 0.40 & + \\
\hline SSA_1172 & & & 0.24 & 0.69 & 1.15 & 1.15 & 1.07 & 0.93 & 0.75 & 0.70 & 1.17 & - \\
\hline SSA_1183 & & -0.36 & -0.12 & 2.36 & 3.82 & 4.10 & 3.54 & 3.35 & 3.04 & 2.89 & 1.49 & - \\
\hline SSA_1184 & topA & -0.26 & -0.12 & 2.76 & 4.10 & 4.39 & 3.78 & 3.54 & 3.11 & 2.98 & 1.69 & - \\
\hline SSA_1185 & smf & 0.23 & & & 5.61 & 5.85 & 6.80 & & 5.81 & 4.81 & 3.42 & - \\
\hline SSA_1207 & pta & -0.24 & -0.20 & 0.06 & 1.75 & 2.70 & 2.58 & 2.47 & 1.82 & 1.33 & 0.56 & - \\
\hline SSA_1208 & & -0.21 & -0.24 & 0.13 & 2.21 & 3.07 & 3.08 & 2.68 & 2.16 & 1.50 & 0.60 & - \\
\hline
\end{tabular}




\begin{tabular}{|c|c|c|c|c|c|c|c|c|c|c|c|c|}
\hline alocus & $\begin{array}{l}\text { bene } \\
\text { Symbol }\end{array}$ & $\begin{array}{c}{ }^{\circ} 0 \text { min } \\
\text { Average }\end{array}$ & $\begin{array}{c}2.5 \mathrm{~min} \\
\text { Average }\end{array}$ & $\begin{array}{c}5 \text { min } \\
\text { Average }\end{array}$ & $\begin{array}{c}7.5 \mathrm{~min} \\
\text { Average }\end{array}$ & $\begin{array}{c}10 \mathrm{~min} \\
\text { Average }\end{array}$ & $\begin{array}{l}12.5 \mathrm{~min} \\
\text { Average }\end{array}$ & $\begin{array}{c}15 \text { min } \\
\text { Average }\end{array}$ & $\begin{array}{l}\text { d } 17.5 \text { min } \\
\text { Average }\end{array}$ & $\begin{array}{c}20 \text { min } \\
\text { Average }\end{array}$ & $\begin{array}{c}30 \text { min } \\
\text { Average }\end{array}$ & $\begin{array}{c}{ }^{\mathrm{e}} \text { Gene } \\
\text { Direction }\end{array}$ \\
\hline SSA_1209 & ppnK & -0.17 & -0.38 & 0.12 & 2.21 & 3.24 & 2.74 & 2.39 & 2.05 & 1.55 & 0.56 & - \\
\hline SSA_1210 & & 0.10 & 0.31 & 0.78 & 2.09 & 3.04 & 3.47 & 3.04 & 2.40 & 1.89 & 1.03 & - \\
\hline SSA_1212 & prs & -0.07 & 0.01 & 0.28 & 1.03 & 1.32 & 2.20 & 1.62 & 1.90 & 0.98 & 0.30 & + \\
\hline SSA_1213 & & -0.09 & -0.13 & 0.32 & 0.02 & 0.14 & 0.29 & 0.46 & 1.20 & 0.61 & -0.04 & + \\
\hline SSA_1214 & & -0.14 & -0.19 & 0.50 & & & & 0.85 & 1.15 & 0.66 & -0.03 & + \\
\hline SSA_1216 & & 0.10 & 0.22 & 1.41 & 0.48 & 0.50 & 0.70 & 0.69 & 0.93 & 1.06 & 1.31 & + \\
\hline SSA_1217 & & -0.03 & 0.14 & 0.94 & 0.27 & 0.51 & 0.42 & 0.04 & 0.52 & 0.63 & 1.20 & + \\
\hline SSA_1218 & radC & -0.02 & 0.87 & 5.19 & 5.39 & 5.74 & 5.54 & 5.61 & 5.29 & 5.33 & 2.80 & - \\
\hline SSA_1235 & pyrC & 0.08 & 0.37 & 1.20 & 2.71 & 3.63 & 3.44 & 2.98 & 2.78 & 2.35 & 0.92 & - \\
\hline SSA_1252 & & -0.26 & -0.35 & 0.53 & 1.40 & 1.27 & 0.09 & -0.67 & 0.40 & 0.80 & 1.31 & - \\
\hline SSA_1314 & & 0.15 & 0.01 & 0.08 & 1.58 & 0.16 & 0.46 & -0.13 & -0.27 & 0.00 & -0.02 & - \\
\hline SSA_1323 & & 0.25 & 0.25 & 0.39 & 1.04 & 1.32 & 0.39 & 0.70 & 0.75 & 0.70 & 1.57 & - \\
\hline SSA_1393 & & & 0.35 & 1.33 & 2.35 & 0.69 & 1.81 & 0.09 & 0.02 & 1.24 & 0.34 & - \\
\hline SSA_1535 & & & -0.22 & 0.65 & 1.08 & & 2.29 & 1.85 & 1.83 & & 0.72 & - \\
\hline SSA_1536 & bioY & 0.21 & 0.25 & 0.20 & 0.26 & 0.74 & 1.13 & 0.83 & 0.72 & 0.39 & 0.25 & + \\
\hline SSA_1537 & & 0.01 & 0.38 & 2.68 & 4.54 & 4.97 & 4.81 & 4.24 & 3.47 & 3.40 & 1.94 & - \\
\hline SSA_1584 & & -0.06 & 0.00 & 0.33 & 1.27 & 0.66 & 0.44 & 0.25 & 0.35 & 0.39 & 0.07 & - \\
\hline SSA_1681 & & -0.22 & -0.19 & 0.73 & 1.15 & 0.36 & 0.02 & -0.30 & 0.14 & 0.62 & 0.28 & - \\
\hline SSA_1711 & nth & -0.28 & -0.24 & 0.23 & 1.27 & 0.50 & 0.27 & -0.39 & -0.23 & 0.25 & -0.12 & - \\
\hline SSA_1713 & serA & 0.06 & 0.12 & 0.51 & 1.29 & 2.07 & 2.65 & 2.27 & 1.71 & 1.34 & 1.41 & - \\
\hline SSA_1715 & serC & 0.08 & 0.02 & 0.86 & 1.45 & 2.20 & 2.77 & 2.58 & 1.94 & 1.93 & 0.94 & - \\
\hline SSA_1716 & & -0.06 & 0.44 & 3.78 & 4.16 & 4.79 & 4.59 & 4.35 & 4.38 & 4.11 & 2.57 & - \\
\hline SSA_1717 & spnIM & 0.01 & 0.58 & 3.83 & 4.36 & 4.86 & 4.71 & 4.62 & 4.36 & 4.23 & 2.51 & - \\
\hline SSA_1812 & & 0.03 & -0.07 & 1.31 & 2.80 & 3.31 & 2.90 & 2.27 & 1.47 & 1.13 & 0.52 & - \\
\hline SSA_1813 & & -0.05 & -0.10 & 1.13 & 2.07 & 2.44 & 2.13 & 1.69 & 0.98 & 0.57 & 0.13 & - \\
\hline SSA_1830 & & 0.09 & 0.13 & 1.36 & 1.73 & 2.55 & 3.27 & 2.57 & 2.00 & 1.79 & 0.56 & + \\
\hline SSA_1831 & recX & & 0.07 & 1.31 & 2.26 & 3.04 & 3.58 & 2.80 & 2.01 & 1.90 & 0.74 & + \\
\hline SSA_1834 & raiA & -0.34 & -0.10 & 2.07 & 3.35 & 3.55 & 3.12 & 2.71 & 2.73 & 2.24 & 1.14 & - \\
\hline SSA_1835 & comFC & 0.24 & 1.27 & 4.75 & 5.30 & 5.00 & 5.08 & 4.72 & & 4.77 & 3.28 & - \\
\hline SSA_1836 & comFA & 0.03 & 1.25 & 5.75 & 5.48 & 6.12 & 5.93 & 5.75 & 5.38 & 5.43 & 3.47 & - \\
\hline SSA_1879 & glys & -0.01 & 0.00 & 0.53 & 1.64 & 0.51 & -0.11 & -0.37 & -0.10 & 0.22 & 0.60 & - \\
\hline SSA_1889 & & 0.19 & 4.46 & 4.97 & 4.81 & 4.29 & 3.49 & 3.74 & 2.69 & 2.66 & 2.61 & - \\
\hline SSA_1975 & & 0.01 & 0.14 & 0.82 & 0.09 & 1.04 & 1.45 & 1.92 & 0.89 & 0.47 & 0.27 & - \\
\hline SSA_2005 & dnaJ & -0.31 & -0.15 & 0.06 & 0.83 & 1.37 & 1.39 & 1.40 & 0.90 & 0.38 & -0.10 & - \\
\hline SSA_2006 & & -0.37 & -0.39 & -0.12 & 0.56 & 1.06 & 1.00 & 0.92 & 0.30 & -0.26 & -0.57 & - \\
\hline
\end{tabular}




\begin{tabular}{|c|c|c|c|c|c|c|c|c|c|c|c|c|}
\hline${ }^{\mathrm{a}}$ locus & $\begin{array}{l}{ }^{b} \text { Gene } \\
\text { Symbol }\end{array}$ & $\begin{array}{l}{ }^{\circ} 0 \mathrm{~min} \\
\text { Average }\end{array}$ & $\begin{array}{c}2.5 \mathrm{~min} \\
\text { Average }\end{array}$ & $\begin{array}{c}5 \text { min } \\
\text { Average }\end{array}$ & $\begin{array}{l}7.5 \mathrm{~min} \\
\text { Average }\end{array}$ & $\begin{array}{c}10 \text { min } \\
\text { Average }\end{array}$ & $\begin{array}{l}12.5 \text { min } \\
\text { Average }\end{array}$ & $\begin{array}{c}15 \text { min } \\
\text { Average }\end{array}$ & $\begin{array}{l}\text { d } 17.5 \text { min } \\
\text { Average }\end{array}$ & $\begin{array}{c}20 \mathrm{~min} \\
\text { Average }\end{array}$ & $\begin{array}{c}30 \text { min } \\
\text { Average }\end{array}$ & $\begin{array}{c}{ }^{\mathrm{e}} \text { Gene } \\
\text { Direction }\end{array}$ \\
\hline SSA_2008 & grpE & 0.01 & -0.04 & 0.04 & 0.65 & 1.18 & 1.12 & 0.92 & 0.09 & -0.29 & -0.45 & - \\
\hline SSA_2036 & & -0.14 & -0.20 & 0.43 & 1.08 & 0.85 & 0.68 & 0.18 & 0.59 & 0.38 & 0.29 & - \\
\hline SSA_2116 & cbf & 0.06 & 0.12 & 1.53 & 3.04 & 3.63 & 3.10 & 2.65 & 2.29 & 1.76 & 0.99 & - \\
\hline SSA_2117 & rmuC & -0.01 & 0.11 & 1.65 & 3.13 & 3.73 & 3.42 & 2.89 & 2.39 & 1.97 & 1.01 & - \\
\hline SSA_2122 & & 0.11 & 0.81 & 1.44 & 3.07 & 2.30 & & 2.79 & 2.17 & 1.63 & 0.34 & - \\
\hline SSA_2156 & & -0.14 & -0.24 & 0.81 & 2.61 & 3.24 & 2.60 & 2.27 & 2.01 & 1.48 & 0.76 & - \\
\hline SSA_2157 & $\operatorname{rad} A$ & 0.17 & 0.15 & 2.42 & 3.83 & 4.04 & 4.00 & 3.90 & 3.04 & 2.96 & 1.76 & - \\
\hline SSA_2159 & & -0.11 & 0.07 & 2.81 & 4.37 & 4.46 & 4.35 & 3.79 & 3.32 & 2.86 & 1.37 & - \\
\hline SSA_2160 & dut & 0.05 & -0.02 & 3.03 & 4.36 & 4.96 & 4.42 & 4.17 & 3.68 & 3.01 & 1.55 & - \\
\hline SSA_2181 & & -0.21 & -0.16 & 0.09 & 1.10 & 0.58 & 0.78 & 0.44 & 0.14 & 0.28 & -0.11 & - \\
\hline SSA_2189 & & & -0.24 & 0.48 & 1.86 & 1.86 & 1.43 & 1.05 & 0.62 & 0.83 & 0.18 & - \\
\hline SSA_2190 & & 0.19 & 0.41 & 0.30 & 0.55 & 0.92 & 1.12 & 1.12 & 1.06 & 0.77 & 0.32 & + \\
\hline SSA_2192 & & -0.03 & 1.17 & 3.40 & 3.98 & 4.31 & 3.93 & 3.85 & 3.43 & 3.53 & 2.02 & - \\
\hline SSA_2231 & & -0.32 & -0.21 & 0.95 & 2.23 & 2.37 & 1.90 & 1.35 & 0.98 & 0.58 & 0.48 & - \\
\hline SSA_2233 & & 0.06 & 0.34 & 2.72 & 2.67 & 2.90 & 4.12 & 3.22 & 2.64 & 1.77 & 1.34 & - \\
\hline SSA_2245 & recA & -0.14 & 0.16 & 2.23 & 3.07 & 3.72 & 3.38 & 3.34 & 3.27 & 2.88 & 1.99 & - \\
\hline SSA_2246 & $\operatorname{cin} A$ & -0.04 & 1.28 & 4.58 & 5.36 & 5.72 & 5.45 & 5.59 & 5.30 & 5.41 & 4.67 & - \\
\hline SSA_2253 & $\operatorname{tag}$ & 0.05 & 0.26 & 0.06 & 0.64 & 1.03 & 1.14 & 0.80 & 0.47 & 0.35 & 0.25 & - \\
\hline SSA_2321 & $\mathrm{czcD}$ & 0.04 & -0.09 & 0.22 & 1.02 & 0.74 & 0.33 & 0.23 & 0.13 & 0.08 & 0.00 & - \\
\hline SSA_2378 & comE & -0.12 & 4.81 & 5.06 & 4.67 & 4.06 & 3.68 & 3.50 & 3.26 & 3.45 & 3.40 & - \\
\hline SSA_2379 & comD & -0.08 & 4.29 & 4.45 & 4.69 & 3.72 & 3.39 & 3.21 & 2.82 & 3.31 & 3.20 & - \\
\hline
\end{tabular}

(a) SSA numbers indicate gene loci with SSA_0001 at the chromosomal origin of replication. Each gene was given a UID number and probes representing these regions were on the microarray slides.

(b) Symbol given to each gene based on the published annotation.

(c) Values shown are the ratio of the value at each time point $(2.5,5,7.5,10,12.5,15,17.5,20$, and 30 minutes) after addition of CSP to the value at time 0 . Data for 0 minute reported here to show comparison values.

(d) Data taken for 17.5 minutes post-CSP exposure is the result of only two individual experiments.

(e) + and - designate the orientation with respect to the origin of replication of the $S$. sanguinis chromosome. 
visualization of data, a colorimetric graph was created using numerical values for all upregulated genes (Figs. 17 and 18).

The values calculated from this study were first clustered based on similar expression patterns using Cluster 3.0. For this study, genes were clustered using the average linkage clustering technique which is a hierarchical agglomerative clustering algorithm. Based on the figures created using the TreeView software, genes were definitively grouped into two categories. Those whose expression was induced at least 4-fold at 2.5 minutes were named "early response genes" due to their immediate expression following CSP exposure. Genes that lagged just behind showing greater than a 3-fold induction no later than 10 minutes post-CSP exposure were termed "late response genes", due to their relatively delayed response to CSP.

For the early response cluster, nine genes were clustered together including the five listed previously (Fig. 17). The other four genes, SSA_0197, 0198, 0199, and 0200 showed minimal up-regulation throughout the time course. Closer observation revealed that all four of these genes were adjacent to each other and were just downstream of the early response gene SSA_0195. Thus, expression of these genes may in fact be caused via transcriptional read through of the terminator sequence in this gene.

The other five genes up-regulated in the early response cluster show that after initial activation at 2.5 minutes, expression of these genes continued throughout the 30 minute time course. After approximately 7.5 - 10 minutes of relatively constant expression, intensity levels began to decay, although never returning to basal levels. This is an interesting observation since competence genes in other streptococcal 
Figure 17. Colorimetric representation of relative expression levels of CSP-induced $S$. sanguinis genes. Expression levels are measured by hybridization to cDNA in four replicate spots on microarray slides. The results are a product of three time courses individually conducted. Shown are the 128 genes up-regulated $>2$-times basal levels in at least one time point and have been identified as significantly expressed based on SAM. The first zoomed cluster contains those genes that were classified as early response genes. The second zoomed clusters are genes that were classified as first-class late response genes. Each expression value was designated a color code to indicate levels of expression. The colors varied from black ( $<2$-fold up-regulation) to bright red (> 32-fold up-regulation). 
Figure 17

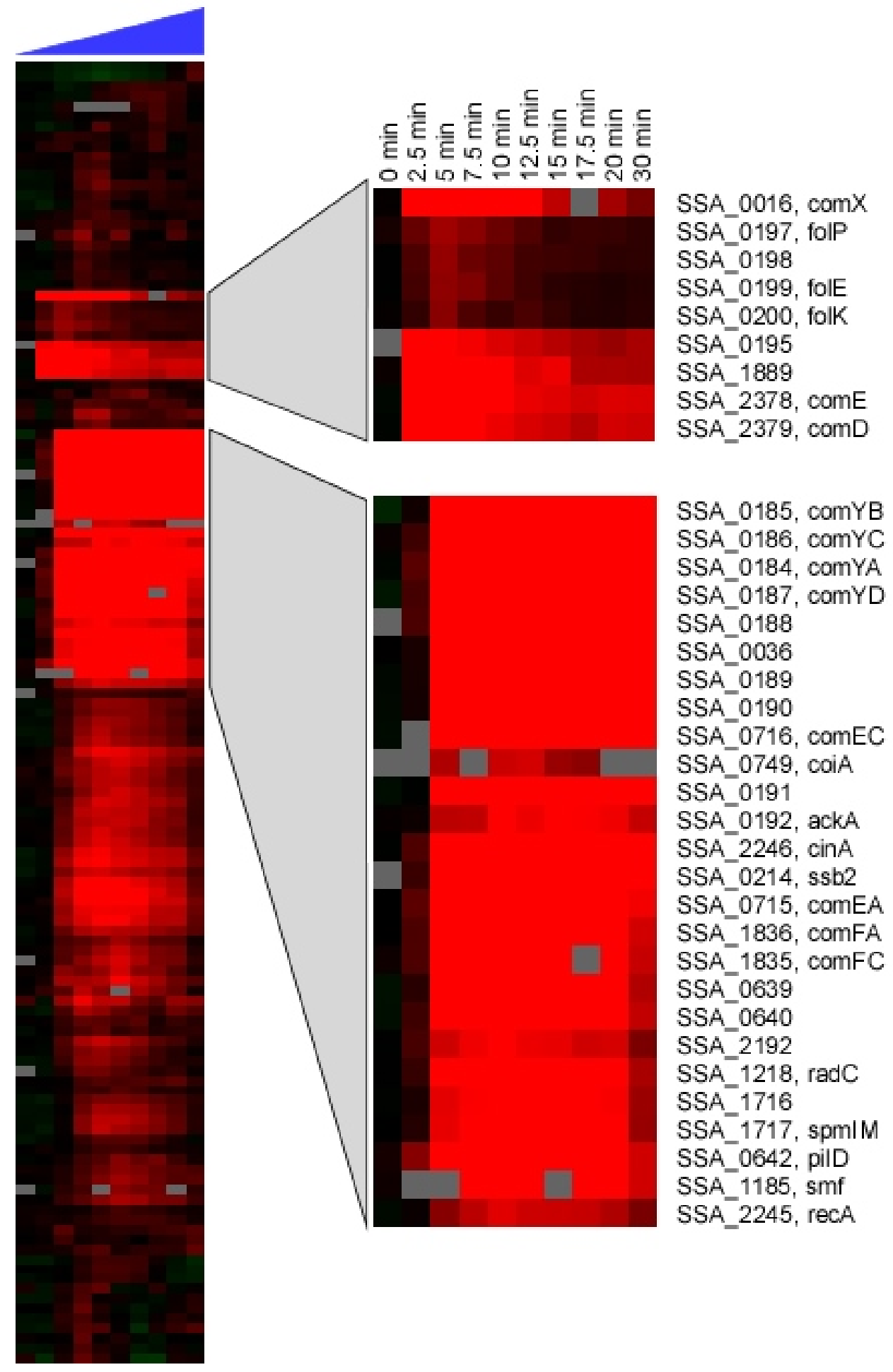


Figure 18. The same colorimetric graph as Figure 17, only focused on the second-class of late response genes. Genes highlighted in red signify those that showed 3-fold induction 5 minutes post-CSP exposure. Genes in blue showed induction starting at 7.5 minutes after CSP-exposure. Lastly, genes in green were shown to be induced greater than 3 -fold after 10 minutes post CSP-exposure. 
Figure 18

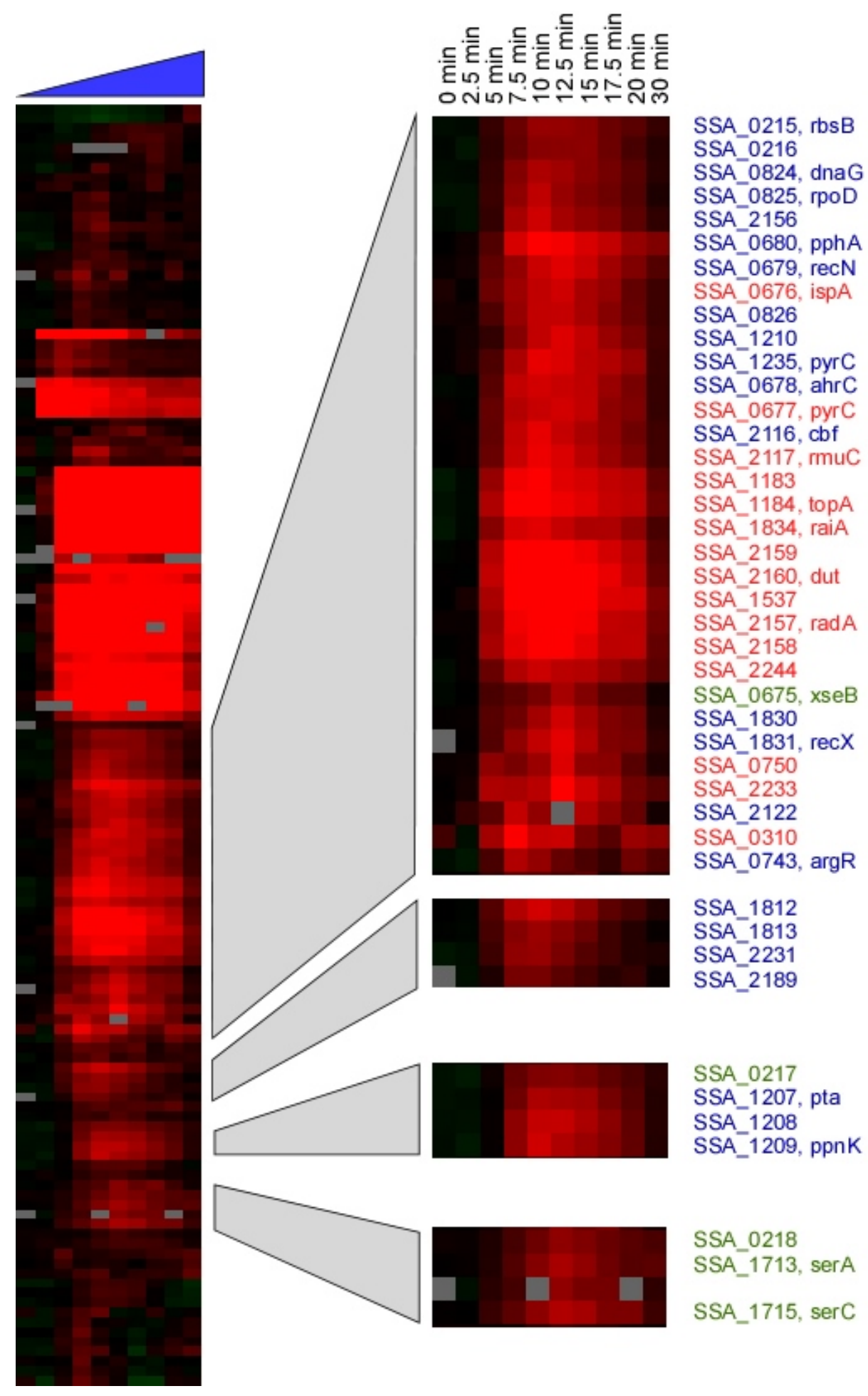


species have a definitive rise and fall of expression. Expression levels for these genes do fall; however the lag is much longer and expression never completely returns to baseline levels over the 30-minute time course.

The finding that late response genes exhibited two distinct expression patterns led to their classification as either "first-" or "second-class late response genes". Genes in the first class are those that are highly up-regulated 5 minutes post-CSP exposure, and remain at high levels through the 30-minute time course. Genes that were classified as second-class late response genes are those that were up-regulated between $5-10$ minutes after CSP exposure. Genes in this class reached 3-fold induction at least once throughout the 30-minutes time course, but their expression levels quickly diminished soon afterwards.

The second cluster in Figure 17 and the expanded clusters in Figure 18 show the first and second classes of "late" response genes respectively based on the criteria described above. Out of the 119 genes that displayed a twofold or greater induction in at least one time point and were not classified as "early" response genes, 69 genes can be characterized as "late" response because up-regulation began no later than 10 minutes post-CSP exposure. Interestingly, out of this pool, seven genes were isolated and not directly adjacent to any other CSP-regulated gene, SSA_0036, 0310, 1537, 2122, radC, pyrC, and ispA (Fig. 19). However, the remaining 62 genes were clustered near or directly adjacent to other genes passing the twofold greater expression filter. Of these 64 late response genes, 9 are putatively situated within the same operon. These include the four comY genes, SSA_0188, 0189, 0190, 0191 and ackA. The remaining 55 genes 
Figure 19. Organization of CSP-induced late response genes. Genes classified as firstclass late response genes are represented in red and genes classified as second-class late response genes shown in black. ORF orientation relative to the chromosomal origin of replication is indicated by the direction of the arrow. 


\section{Figure 19}
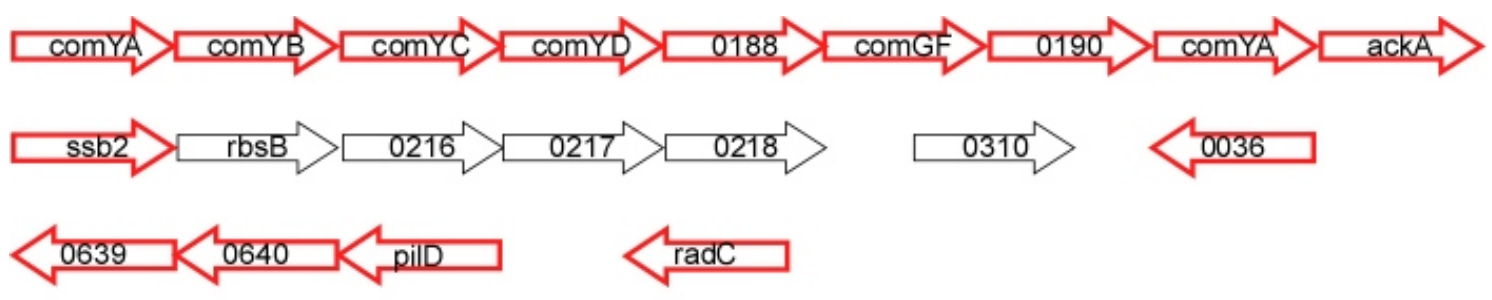

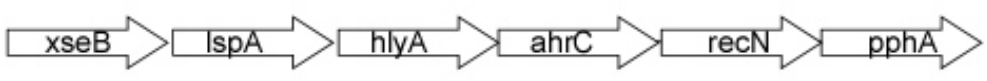

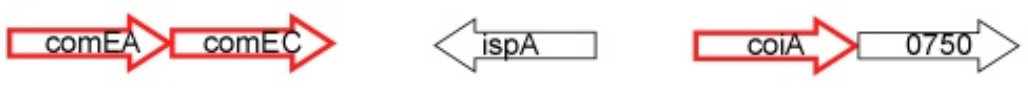

$\mid$ dnaG $>$ rpoD $>0826><1812<1813<<<1537$

$<1183<$ topA $<$ smf $<$ pta $<1208<1209<\frac{\text { ppnK }}{2122}$

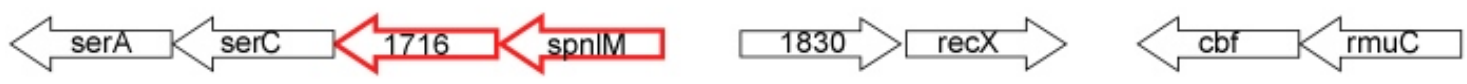

$<1834<$ comFC $<$ comFA $<2156<2157<2158<2159<\frac{2 \text { dut }}{215}$

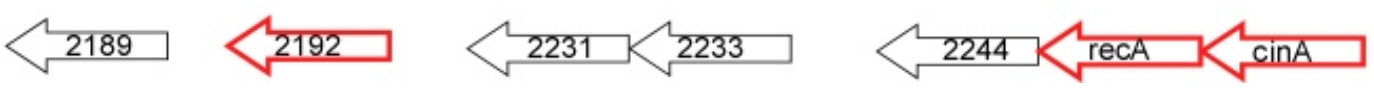


are organized in clusters of two or more adjacent genes that lie in similar orientations and exhibit similar temporal expression patterns. Additionally, ssb2, coiA, smf, spnlM, $\operatorname{comFA}$, and $\operatorname{cin} A$ are part of unique operons that are clustered together due to their similar expression patterns and categorized as first-class late response genes (Fig. 17). However, these genes lie upstream of other genes that are seemingly co-transcribed and are shown to be up-regulated, yet clustered in the second class of late response genes (Fig. 19), indicating a slightly different temporal regulation.

In the first 26-gene set (Fig. 17), late response genes were activated 5 minutes post-CSP exposure and, just as with the early response genes, remained active throughout the 30-minute time course. Unlike the early genes, these late genes remained up-regulated at high levels with the exception of most notably comFA and comFC which began to show signs of repression at the 30-minute mark. The second class of late genes activated (Fig. 18) showed induction between 5 and 10 minutes after CSP exposure. Unlike what has been seen in the first class of late genes, expression of these genes rose and fell within the 30-minute time course. This second class contains 11 hypothetical proteins as well as 5 different proteins dealing with DNA recombination and repair. As has been noted before (Fig. 19), many of these genes lie just downstream or directly adjacent to other up-regulated genes observed in the first cluster, yet vary in their expression levels.

Lastly, the remaining 49 genes that showed 2-fold levels of induction in at least one time point were grouped into a final category termed "delayed response genes", due in part to the lengthy delay between the late genes and these genes, and also because 
expression was minimal. Expression of these genes occurred approximately 15 minutes after initial exposure with CSP. Unlike what was observed for the previous two categories, expression barely made the cut-off and quickly dropped to below acceptable levels after a few minutes. Most of these genes are annotated as heat shock proteins, DNA recombination proteins, and co-chaperonins (i.e. SSA_2008, dnaJ, and groS respectively). The fact that expression of these genes is minimal and their patterns highly different from those characterized previously, suggests that regulation of these genes may not be via a ComE or ComX dependent pathway. Alternatively, their proximity to other highly regulated genes also suggests that regulation may have been incidental.

\section{H. Putative competence genes are shown to be activated in $S$. sanguinis via microarray analysis in response to CSP treatment.}

A total of 22 genes that are up-regulated in response to CSP in S. pneumoniae have been shown to be indispensable for competence (84). In order to determine if these same genes are present and similarly regulated in S. sanguinis, the translated sequences were retrieved, and a BLASTP search was performed with them in an attempt to look for homologs in S. sanguinis. In the TIGR4 strain, eight of the genes that were found to be indispensable for competence were classified as early response genes. Out of these eight, only four genes were found to have homologs in S. sanguinis: comCDE, and $\operatorname{comX}$ (Table 5). Since a comC mutant was used for these arrays, no data were collected for this gene. However, considering that $c o m D E$ were up-regulated and are likely cotranscribed along with $\operatorname{com} C$, it is reasonable to assume that $\operatorname{com} C$ would normally be 
Table 5. The results of a BLASTP search in which the protein sequences of genes known to be indispensable for competence in S. pneumoniae strain TIGR4 were used as query sequences to search for orthologs in S. sanguinis. 
Table 5

\begin{tabular}{lcc}
\hline \multicolumn{1}{c}{ S. pneumoniae } & \multicolumn{2}{c}{ S. sanguinis } \\
locus & Ortholog & Upregulated \\
\hline Early & & \\
SP_0014, comX & SSA_0016, comX & Yes \\
SP_0018, comW & None & N/A \\
SP_0042, comA & None & N/A \\
SP_0043, comB & None & N/A \\
SP_2006, comX2 & None & N/A \\
SP_2235, comE & SSA_2378, comE & Yes \\
SP_2236, comD & SSA_2379, comD & Yes \\
SP_2237, comC & SSA_2394, comC & N/A \\
Late & & \\
SP_0954, comEA & SSA_0715, comEA & Yes \\
SP_0955, comEB & SSA_0716, comEC & Yes \\
SP_0978, coiA & SSA_0749, coiA & Yes \\
SP_1266, dprA & SSA_1185, smf & Yes \\
SP_1808, pilD & SSA_0642, pilD & Yes \\
SP_1908, ssbB & SSA_0214, ssb2 & Yes \\
SP_1940, recA & SSA_2245, recA & Yes \\
SP_2047, hyp. prot. & SSA_0190, hyp. prot. & Yes \\
SP_2050, cglD & SSA_0187, comYD & Yes \\
SP_2051, cglC & SSA_0186, comYC & Yes \\
SP_2052, cglB & SSA_0185, comYB & Yes \\
SP_2053, cglA & SSA_0184, comYA & Yes \\
SP_2207, cflB & SSA_1835, comFC & Yes \\
SP_2208, cflA & SSA_1836, comFA & Yes \\
& &
\end{tabular}


up-regulated in SK36. Orthologs of the remaining four genes have not been identified in S. sanguinis. The gene for ComW, a protein believed to be responsible for stabilizing ComX, as well as $\operatorname{com} X 2$ (an identical second $\operatorname{com} X$ gene) have been shown to be absent in S. sanguinis (113); comAB has also eluded detection.

The remaining 14 indispensable genes are classified under "late response". All 14 genes contain homologs in S. sanguinis. In all cases, the microarray results showed that these genes were up-regulated in rather strong fashion and were clustered together in the first class of late response genes (Fig.17). Interestingly, the function of SSA_0190 has yet to be determined and is classified as simply a hypothetical protein. Nevertheless, in both the TIGR4 strain and S. sanguinis, expression of this gene is high when cells are induced to competence. Although it can be speculated that these genes are essential for competence given their homology to known indispensable genes in S. pneumoniae, further investigations specifically targeting these genes must be performed before this is concluded in S. sanguinis.

\section{Examination of sequences upstream of highly expressed CSP-induced genes reveals a putative “com-box” for late response genes.}

In order to look at putative promoter sequences under the control of either ComE or ComX for early and late response genes respectively, the SK36 genome was searched using the fuzznuc program from the EMBOSS suite http://www.ch.embnet.org/EMBOSS/index.html. For the late response genes, a model was based on the findings of Campbell et al. (9) for S. pneumoniae. Based on their findings that a conserved octamer was observed upstream of these late response genes 
and that it was likely the region that ComX bound thus promoting transcription, the $S$. sanguinis genome was also searched for a similarly conserved region, also known as the "com-box". Based on a strict interpretation of the model with no tolerance for mismatches, 14 matching sequences were located. Out of these 14, eight were found within genes and were concluded unlikely to be binding sites for ComX. Another two were found upstream of SSA_2192 and pyrC, two genes classified as late response genes based on the findings detailed above. The remaining four sites were found to be upstream of comEA, comFA, pilD, and $\operatorname{smf}$ (Table 6). When the parameters were loosened to allow up to one mismatch, octamers upstream of comYA, coiA, and ssb2 was discovered. Thus the only missing gene from the list gathered from before (Table 5) was recA. Closer analysis of this gene revealed that it was the second gene in an operon just downstream of $\operatorname{cin} A$. Surveillance of the upstream region from $\operatorname{cin} A$ revealed a putative conserved sequence $177 \mathrm{bp}$ upstream from the start site. However, this putative com-box contained two mismatches (Table 6). The com-box was not found immediately upstream of SSA_0185, 0186, 0187, or 0190, nor of 0716 or 1835 . In summary, all late response genes that share homology to genes in S. pneumoniae that have been confirmed as essential for competence, contained conserved putative comboxes upstream of their start sites. The only gene not directly downstream of the putative promoter sequence is $r e c A$.

Interestingly, when the model created by Ween et al. (110) was used to search for possible ComE binding sites, only three regions were located throughout the genome and only comC lay just downstream of the putative promoter. com $X$, 
Table 6. This table shows the results of a fuzznuc analysis of $S$. sanguinis using the model for the conserved octamer upstream of the late response genes established in $S$. pneumoniae strain, TIGR4. The position of the putative com-box relative to the gene start site is listed. 
Table 6

\begin{tabular}{|c|c|}
\hline TIGR4 & TTTT - $(0,12)$ - TACGAATA - $(0,212)$ - ATG \\
\hline comYA & TTTTT $-----\odot-$ TgCGAATA -----48 - ATG \\
\hline ssb2 & CTTT - - - - - - - - TACGAATg - - - - - 21 - ATG \\
\hline pild & TTTTT - - - - -11 - TACGAATA - - - - - - 8 - AT \\
\hline COMEA & TTTTT - - - - - 9- TACGAATA - \\
\hline CoiA & $--\odot-$ TgCGAATA- \\
\hline$s m f$ & $--\odot-$ TACGAATA - - - - 19-AT \\
\hline comFA & TTTT - - - - 10-TACGAATA - - - - - 8 - AT \\
\hline $\operatorname{cin} A$ & СTTT - - - - 1-TtCaAATA - - - -177-AT \\
\hline
\end{tabular}


SSA_1889, and SSA_0195 lacked this promoter sequence suggesting that regulation of these early genes may not follow the same model that has been established for $S$. pneumoniae. In order to determine if a conserved region was located upstream to the gene start site that could be considered an operator site, the sequences were aligned using the ClustalW program analyzing the first 117-bp upstream from the start site. After alignment, the results showed that there were several regions where all sequences aligned well (Table 7). At the -55 site, the $\operatorname{com} C$ sequence contains a TATTT which is shared with comX and SSA 1889 and only partially with SSA_0195. If the latter two are removed, this conservation is extended further to include CTTTCTATTT. Additionally, 29-bp upstream to this region is another sequence, AAANNAt, which is conserved between all four sequences. Because the microarray result limits us to these four early response genes, it is difficult to create a model based on this small of a pool. Further investigation looking at putative promoter sequences for these early response genes will have to be performed in the future.

\section{J. Examination of temporal regulation of selected competence genes via qRT-PCR.}

To confirm the results observed from the microarrays and to obtain more quantitative analysis of transcriptional regulation in S. sanguinis, qRT-PCR reactions were performed. RNA samples were taken from each time point, and primers developed to quantitate three early response genes $-\operatorname{comD}, \operatorname{com} E$, and $\operatorname{com} X-$ and two late response genes - comYD, and comEA. The data for each gene were normalized to tuf. This gene was selected for normalization based on microarray results showing that expression for this gene remained constant and high throughout the 30-min CSP time 
Table 7. Sequence alignment of the regions upstream from four early response genes using ClustalW. 
Table 7

comC
comX
SSA_1889
SSA_0195
ComC
comX
SSA_1889
SSA_0195

ComC
ComX
SSA_1889
SSA_0195

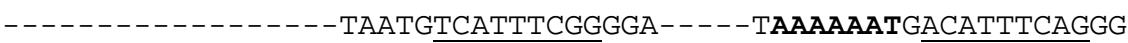
- - - - - ACTTAAAAATAGTTATTCGAGTCAGAAGAGCTCCTAAAATATG - CTTTTTAGAA - - - - - - - AATGCCTTAATAATTCATTTTTAAAGAG - - - - AAATAATCCCCATCCGAAG GAAAGTAGAGAATATCTGCTTTTTTTGTCATTTGAGG - CACAAATTAGgACATTTGAGGG

- -AAAATTGTCACTAACTCTTTCTATTTTTCTATAATGATAAATGTAAGgTGACTTACAA - - GAAAGAGCCCACCTTGCTTTCTATTTA-CAGTAGAATTAA - - GTCAAGTAAATTTTAA TTAAAGAAATTATCAGGTGGGGATATTTTATGTCTTTGATTTTGAAAAGGTGCTATTTCA - - - GATTTCTACCAGCTTGCTCTTACTT - CTTCTATAATGA - - TAAGAGAAGAATGGA

GATAAAAAGATAGGAGATAGTTATG

GGAGGAACT - . - . - . - - - ATG

GGGATAAAAA - - - - - - - ATG

GAGAAT - - - - - - - - - ATG

*

*Note: underlined region in the $\operatorname{com} C$ sequence represents the conserved sequences matching the model established by Ween et al. (110). 
course. As an additional control, the housekeeping gene, gapA, was also included in the analysis.

Analysis reveals that, just as in the microarrays, early genes were activated only 2.5 minutes after CSP induction (Fig 20A). Messenger RNA levels reached a maximum approximately 5 minutes post-CSP exposure. Transcript levels then decreased, although never fully returning to baseline levels. Similarly, late response genes exhibited a small 2.5-minute lag before being activated (Fig. 20B). The comEA gene showed expression levels that were quite high at $2.5 \mathrm{~min}$, although not as high as $\operatorname{com} X$. Both comEA and comYD showed maximal expression 15 minutes after CSP exposure. When putting the two graphs together, there is a definitive overlap between the two classifications of genes (Fig. 20C). The high transcript levels in both late response genes may also give insight to what was observed in the microarrays. Late response genes in the microarrays were determined to remain at constant high levels. The qRT-PCR results showed transcript levels did in fact drop after reaching maximum levels, but perhaps not enough to have been observed in the microarrays.

In summary, the qRT-PCR analysis reveals two waves of overlapping transcription. The early response genes were turned on starting at 2.5 minutes, but reached maximum levels at 5 minutes. It would appear that the 30 -minute time period is not sufficient to reveal the point at which these early response genes return to baseline expression. For the first-class late response genes, it appears that mRNA levels rose dramatically after 2.5 minutes of lag time, reaching a maximum expression level at 15 
Figure 20. The results of qRT-PCR analysis on samples prepared at the indicated times. Values were plotted based on relative expression levels compared to the values obtained at time 0 . The $\log$ base 2 of these results are plotted. A) Results for the early response genes. B) Results for the late response genes. C) The combined results for both waves of transcription including the plotted values for gapA. Error bars omitted for simplicity. 
Figure 20

A.

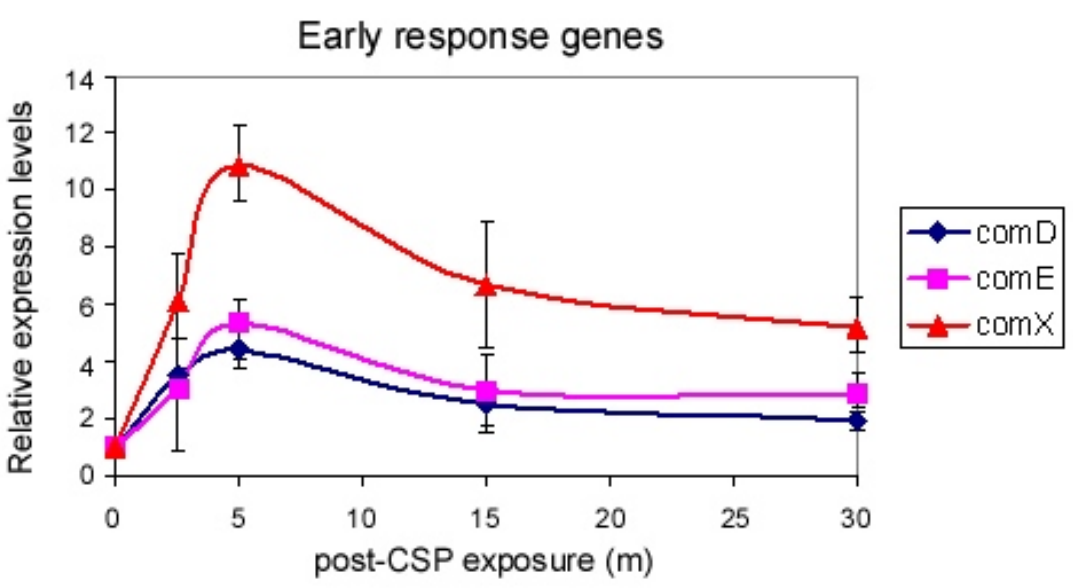

B.

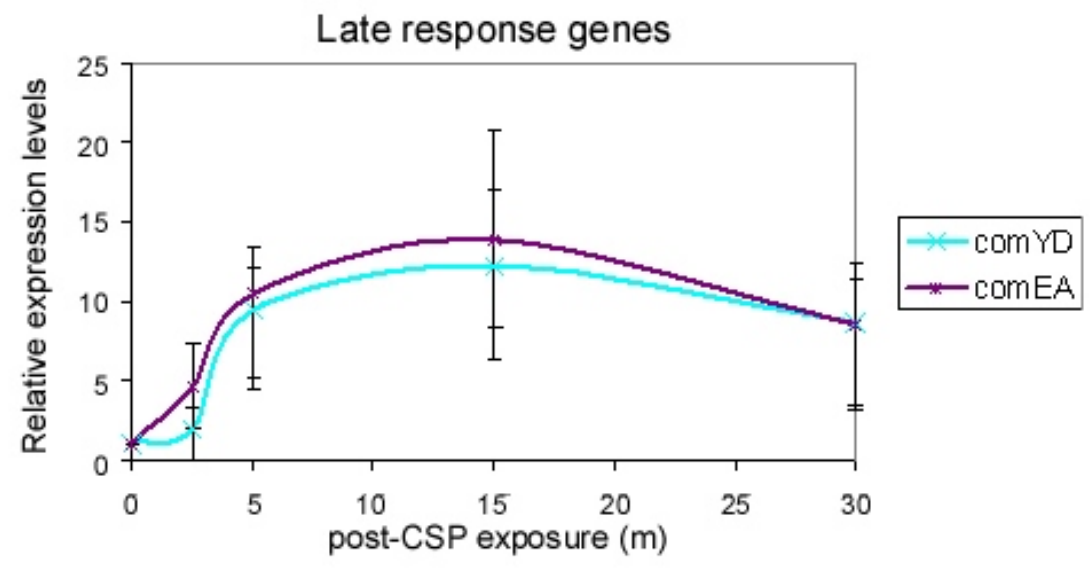

c.

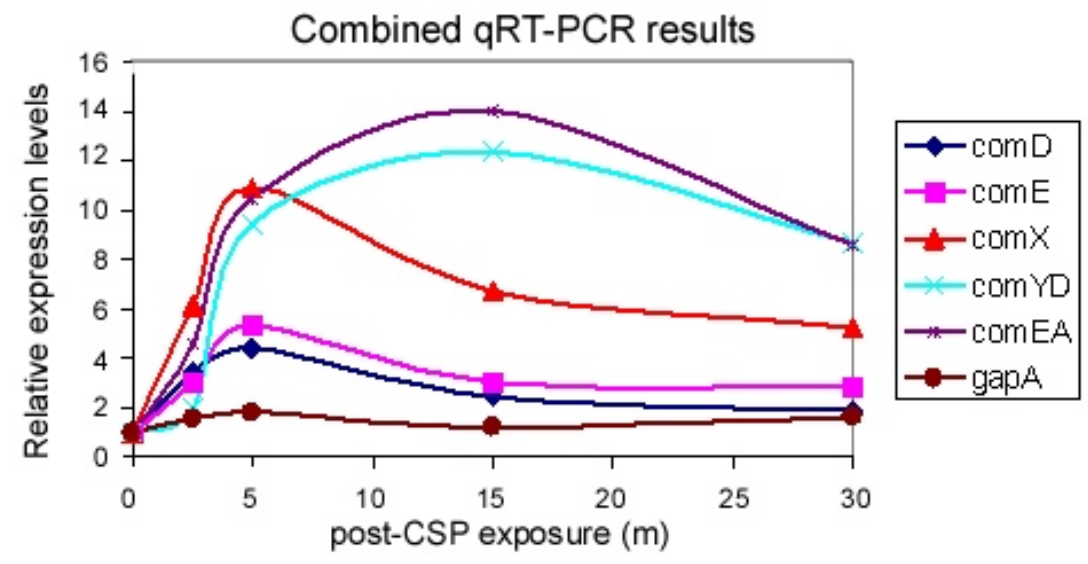


minutes. Just as in the early response genes, expression levels began to decay immediately following peak levels. The results here verify the data observed with the microarrays. 


\section{DISCUSSION}

The evolutionary implication of a competent organism becomes immediately apparent when considering the subsequent adaptability of the cell to environmental cues. Importantly, it has also been shown that competence can benefit bacteria by conferring upon them the ability of picking up antibiotic resistance genes. Besides conferring upon cells new properties, it has also been suggested that the uptake of extracellular DNA can serve as a carbon source for many bacteria (24). As was stated earlier, the presence of platelets aggregated to the damaged endothelium of heart valves predisposes an individual to infective endocarditis. As $S$. sanguinis adheres to these platelets, a vegetation is formed which has some characteristics of biofilms. Biofilms in other streptococcal species have been shown to be affected in competence mutants $(60$, 77). Therefore, considering that $S$. sanguinis is one of the first colonizers of the oral cavity (57) and that it has been implicated as a causative agent of infective endocarditis (73), the necessity to genetically characterize the regulation of competence becomes evident.

The attainment of competence can be repressed by growing, at least some streptococcal species, in acidic conditions. However, unlike what has been seen before $(84,108)$ in other streptococcal species, growing SK36 in these conditions not only abolishes competence, but also negatively affects the growth rate of the bacterium. It is not understood why S. sanguinis is much more sensitive to $\mathrm{pH}$ than other streptococcal species examined, though it is not entirely implausible to believe that these conditions 
cause the transcription of stress response genes, allocating cell resources away from growth activators and more towards repairing the cell wall for example. It could very well affect another quorum sensing mechanism entirely devoted to population control such as in Staphylococcus aureus which contains a two-component system that regulates the timing of population growth by cross-talking with other cells in the vicinity (reviewed in reference (31)). By sensing these nearby cells, S. aureus senses when to start and end exponential growth.

As was originally noted by Tomasz and Hotchkiss (104), competence seems to develop and decay in S. pneumoniae based on cell density. The result from Section A of the Results section implicates $S$. sanguinis as an additional streptococcal species with similar characteristics. It should be noted that as cultures reach stationary phase, the media will gradually become acidic. Studies determining if the drop in competence observed in Figure 4 is a result of the acidity of the media are currently ongoing. It has been observed that the density dependence for spontaneous competence in $S$. pneumoniae is eliminated once a large dose of exogenous CSP is applied to cells (35). Thus, competence is altered from that of cell density-dependence to CSP-dependence. It has been hypothesized that the decay of competence may be mediated by genes upregulated via a ComX-dependent pathway (56). Therefore, as ComX is produced during the competent phase of the streptococcal species, genes required for repression of this stage are also transcribed. Section E of the Results section shows that the mechanism of competence repression may not fit this model entirely. Though no definitive trend was observed at low cell density, when JFP41 was at high cell densities, competence 
appeared to be repressed, albeit not as dramatically as it was observed in SK36, even in the presence of saturating concentrations of CSP.

The findings implicate a second regulatory system partially involved in the repression of competence. It has been observed that competence may also be repressed in oxygen limiting conditions via a two-component system (21). However, transformation conditions were essentially performed aerobically in this study, and oxygen limitation thus can not be implicated here. A potential explanation of these results can be made through the observation of the role of LuxS in repression of competence (92). The study showed a hierarchy of regulation whereby LuxS was involved in the repression of competence, but not as highly as CiaRH and StkP in S. pneumoniae. Therefore, further investigation into the regulatory mechanism of natural competence in S. sanguinis must be performed.

The physiological characterization of competence in the comC mutant was critical for the success of the microarray analysis, which was a major component of this project. Unlike what has been seen in S. gordonii where varying concentrations of CSP had no effect on competence (108), in JFP41, competence appeared to resemble that of S. mutans (47) which showed a more linear dose-like response to CSP (see Results, Section D), plateauing at approximately $200-240 \mathrm{ng} \mathrm{ml}^{-1}$. Thus, a CSP concentration within this range was used for the microarray studies. As briefly mentioned above, even though natural competence was abolished in JFP41, transformation frequencies were negatively affected at high cell densities. The microarray studies were therefore performed at a density that was optimal for transformation in SK36, ensuring that 
experiments would be performed under relevant conditions (see Results, Section A). Lastly, since the microarrays were examining genes induced by CSP, it was necessary to determine the duration of competence in the mutant strain. It was shown that competence peaked 10 minutes following CSP exposure, and abruptly dropped, reaching low transformation frequencies after 30 minutes. Thus the results suggest that regulation of competence occurs within a 30-minute time period.

Studies have shown that once competence is induced in S. pneumoniae, it appears for approximately one hour before transformation frequencies begin to drop below the level of detection $(14,104)$. Typically, optical density readings will be within $0.1-0.2$ from the start to end of competence. In both S. pneumoniae and S. sanguinis, competence occurs at early- to mid-log phase. Comparatively speaking, the results presented here differ somewhat in that competence occurs for a longer period of time in S. sanguinis than in S. pneumoniae, although still occurring early in the exponential phase of growth. Transformation frequencies of 3\% and above can be attained at an $\mathrm{OD}_{660}$ of $0.030-0.600$ (data not shown), indicating cell densities between $6 \times 10^{5}-1 \mathrm{x}$ $10^{8} \mathrm{CFU} \mathrm{ml} \mathrm{m}^{-1}$. Assuming a doubling time of 40 minutes, this equates to 4.5 hours of recoverable transformants. For the comC mutant with respect to duration of competence, the results in this study are similar to what was observed in S. gordonii under acidic conditions in the presence of exogenous CSP (108). That is to say, within the first 30 minutes post-CSP exposure competence abruptly peaked, and similarly dropped, thus suggesting similar regulation in both species. 
Two previous studies in S. pneumoniae and S. gordonii have looked at the genome-wide transcription of genes after induction of competence $(83,108)$. In both studies, repression of endogenous CSP was obtained by growing the strains in acidic conditions. The microarray studies in this project were performed with a comC mutant strain, JFP41. Extensive planning was performed in order to ensure that the reading frames for the flanking genes were maintained and that no polar effects on downstream genes would occur. The use of JFP41 solved a major issue to facilitate the microarray analysis; it allowed for the induction of competence without having to grow cells in any media other than what is normally used for the transformation of SK36, and thus avoided the possible complication of growing the strain in conditions which may alter gene regulation or even up-regulate stress response genes that would otherwise not be affected in normal conditions.

The results of the microarray experiment are similar to what has been observed in S. pneumoniae and in S. gordonii $(83,84,108)$. Transcription of these competence genes follows two waves: genes that are expressed early and are consequently regulated in one manner and late response genes that are regulated via an alternate route. Transcript levels of the early genes were up-regulated within 2.5 minutes of CSP exposure. Within the next 2.5 minutes, ComX had been produced and was presumably actively binding to conserved sequences and increasing late gene mRNA transcript levels seeing as late response genes were being up-regulated. A similar pattern is seen in S. pneumoniae where it was observed that transcript levels begin to rise immediately after exposure to CSP, reaching maximum expression 7.5 - 10 minutes after CSP 
induction. Late response genes lagged just behind these early responders beginning their up-regulation at 5 minutes, and reaching maximum levels approximately 15 minutes post-CSP exposure. In S. gordonii, the early induced genes were similarly expressed. However, late response genes were not up-regulated until 15 minutes after initial induction; a significant lag compared to the previous two.

The results also show that for all genes that are homologs of those essential for competence in S. pneumoniae (comCDEX, comEA/C, comYA/B/C/D, comFA/C, coiA, recA, smf, pilD, ssb2, and SSA_0190), regulation appears to occur at the transcriptional level. Transcription of all early response genes occur in parallel as well as all late response genes, and mRNA transcript levels rise accordingly, suggesting that each gene classified under one of these headings is regulated by a similar promoter. Searching the S. sanguinis genome using Fuzznuc revealed that all late response genes shown to be essential for competence in $S$. pneumoniae contained the same 8 bp region (TACGAATA) preceded by a string of [CT]TTT no more than $12 \mathrm{bp}$ away. The only notable difference was seen in recA. For this gene, the putative com-box contains two mismatches, does not serve as the immediate upstream promoter sequence, and is greater than $150 \mathrm{bp}$ away from the start site. However, considering that $\operatorname{cin} A$ is the immediate downstream gene and has been shown to be up-regulated in competence induction in other studies $(83,108)$, and classified as a late gene, this may in fact be the binding site for activation of transcription for this operon. In S. gordonii, a total of 12 CSP-induced genes were found to contain this sequence upstream from their start site; 
notably the comY, cinArecA, comF operons, and pilD had this sequence upstream from their start sites just as in this study (108).

It should be noted that the model used in S. pneumoniae for the com-box sequence may not be fully conserved in all competent streptococci and may not represent the actual com-box in S. sanguinis. As stated in the Results section (see Section I), using a strict interpretation of the model, only 14 sites were discovered throughout the genome; 8 of which lay in the middle of genes. When the model was loosened to allow one mismatch, the number of hits increased dramatically (data not shown). Most of these hits lay in the middle of genes and had no effect on transcription. Interestingly, many genes not found to be up-regulated via microarray analysis contained this putative promoter just upstream of their start sites. The fact that there was no change of expression in these genes indicates that the model being used may not be entirely sound in S. sanguinis. Additionally, many genes that were up-regulated also contained an additional string of TTTT. However, when the model was updated to incorporate this new set of T's, it was observed that this sequence was also found in the middle of many genes and also upstream of genes not regulated in competence. These results show that the com-box sequence has yet to be fully elucidated in S. sanguinis and thus further investigation must be performed to determine all elements of the combox.

Conversely, using the model established by Ween et al. (110) for ComE binding sites, only three hits were seen throughout the S. sanguinis genome, and only one was upstream of a highly up-regulated operon, comCDE. comX, SSA_1889, and SSA_0195 
did not have this putative promoter sequence. When the upstream sequences of all four early response genes were aligned, multiple regions were found to be similar. Most notable was a 5-bp sequence just upstream of their start sites (TATTT; see Results Section I) and another 7-bp (AAA[AT][AT]A[TG]) region between 28 - 29-bp upstream from that. Including only comC and $\operatorname{com} X$, the former sequence would expand to a 10-bp CTTTCTATTT. It should be noted that this small 7-bp sequence could in fact represent a putative UP element in this upstream region. It would be quite enticing to suggest that these sequences are in fact the actual ComE binding site for these early response genes, however further investigation must first be performed before this is concluded. In S. gordonii, the direct repeats described in the model were missing upstream from their early response genes as well. The fact that in two separate streptococcal species, the expected ComE box sequence was missing indicates the necessity to extensively study the upstream sequences for these early response genes. Expression of the first class of late genes (see Results, Fig. 17) was different than that of the second class of late genes (see Results, Fig. 18). In many cases, the second class of late genes lay directly adjacent to the first class of late genes suggesting that they may be co-transcribed (see Results, Fig.19); the fact that expression in both classes begins at the same time supports this hypothesis. However, after $12.5 \pm 2.5$ minutes of expression, transcript levels drop. This abrupt change in transcript levels, even though they may in fact be transcribed simultaneously, suggests that unique transcriptional regulation for each gene plays a vital role in competence. Indeed, expression of recA appeared to fluctuate throughout the 30 -min time course which 
supports earlier findings detailing the differences in changes of expression in $S$. pneumoniae for recA (45). It is important to note, however, that this relatively low expression compared to other genes in the first class may be due to the weak putative promoter sequence discovered using Fuzznuc. It should be noted that the observed drop in transcript levels may also indicate a loss of mRNA stability within the cell. It may also indicate that initial transcription may have occurred due to transcriptional readthrough of the terminator sequences just upstream from these first class genes. As transcription of first-class late response genes begins to drop, so does the frequency with which transcriptional read-through occurs and thus transcription levels for these downstream genes is negatively affected.

It is quite interesting to observe the relative expression levels of genes that seem to play no role in the induction of competence, but are in fact up-regulated when the cells become competent. As noted in the Results section (see Section G), a total of 128 genes in S. sanguinis were found to be up-regulated in response to exposure with CSP; however only 17 genes $(\sim 13.3 \%)$ have homologs in $S$. pneumoniae that have been shown to be essential for competence. The vast majority of genes up-regulated by CSP in S. sanguinis are probably also not essential for competence. It has been suggested that transcription of genes not essential for competence in S. pneumoniae occurs due to their close proximity to other highly expressed genes with a putative com-box (83). Many of these genes encode proteins involved in DNA recombination and repair and transcriptional regulators. Though not important for induction of competence, it is apparent how these proteins would be useful when introducing foreign DNA into the 
genome. Evolutionarily speaking, the clustering of these genes near CSP-induced genes may confer a Darwinian advantage for the species. Thus, instead of allocating resources such as polymerases and ribosomal proteins to each individual gene with the ultimate goal of acquiring foreign DNA from the environment, only a select few absolutely critical genes are directly regulated via CSP, and the rest are selectively placed in a location to benefit from their transcription. It has also been suggested that many of these clustered genes in S. pneumoniae take part in the killing of surrounding cells (13). Whether or not this occurs in S. sanguinis has yet to be elucidated and requires further investigation.

Summarizing the microarray results, the number of genes that were up-regulated in response to CSP in this study was shown to be 128 . Out of this lot, 69 were classified as late response genes and only 5 classified as early. The remaining 54 genes showed a maximum of 2 to 3 -fold expression approximately 15 - 20 minutes after initial exposure with CSP. The number of CSP-induced genes in S. pneumoniae and S. gordonii was 188 and 177 respectively ( $\sim 50 \%$ more). A total of 19 genes in S. pneumoniae were classified as "delayed response", and nearly half of these were deemed ComXindependent. Interestingly, many of these genes were stress response genes such as groES, and dnaJ. The acidic conditions SK36 was grown in caused a deleterious effect on growth. This condition could very well account for the number of "delayed" response genes observed in S. pneumoniae. However, S. gordonii was grown in similar conditions and induced to competence in the same manner; yet very few delayed genes were observed, and expression of these stress response genes was minimal, suggesting 
that the observation of delayed response genes may not have to do with growth conditions.

In S. gordonii, 127 late response genes were detected. The number of genes in this category compared to S. pneumoniae and S. sanguinis is quite large. Additionally, the lengthy lag between early and late response genes may also have been caused by the differences in CSP concentration used to induce the cells. Whereas in S. pneumoniae and in this study, the concentration of CSP used was 200 and $220 \mathrm{ng} \mathrm{ml}^{-1}$ respectively, the concentration used in the former study was only $100 \mathrm{ng} \mathrm{ml}^{-1}$; though it should be noted that varying concentrations of CSP showed no increase in number of transformants recovered in S. gordonii. Another explanation for the larger pool of categorized "late response" genes may be due to their experimental procedure where only the 5 and 15 minutes after initial exposure with CSP were analyzed. Nevertheless, further investigations dealing with varying growth conditions should be performed to study their specific effects in S. sanguinis.

The sequences of the proteins encoded by the 69 late response genes observed in S. sanguinis were used to search for similarly up-regulated genes in S. pneumoniae and S. gordonii (Table 8), which were clustered into 25 unique operons (see Fig. 19). In the former species, homologs of 55 out of the 69 late response genes were identified, 34 of which were shown to be similarly up-regulated. In S. gordonii, 61 homologs were identified and 40 of those genes were up-regulated in a similar fashion. Besides the similarities between the three species, the differences are interesting to note. SSA_1713, 1715 , and 1716 share no homology to either species, however, SSA_1717 is 
Table 8. Orthologs in S. pneumoniae and S. gordonii of the 69 S. sanguinis late response genes initially discussed in Section G of the Results section. "+" denotes genes that were found to be up-regulated in their respective studies. Blank spaces indicate that no orthologs were discovered for this gene. 
Table 8

\begin{tabular}{|c|c|c|c|c|}
\hline $\begin{array}{l}\text { S. sanguinis } \\
\text { Ortholog }\end{array}$ & $\begin{array}{c}\text { S. pneumoniae } \\
\text { Ortholog }\end{array}$ & $\begin{array}{c}\text { Up- } \\
\text { regulated }\end{array}$ & $\begin{array}{l}\text { S. gordonii } \\
\text { Ortholog }\end{array}$ & $\begin{array}{c}\text { Up- } \\
\text { regulated }\end{array}$ \\
\hline SSA_0036 & SP_2216 & - & SGO_2094 & + \\
\hline SSA_0184, comYA & SP_2053 & + & SGO_1924 & + \\
\hline SSA_0185, comYB & SP_2052 & + & SGO_1923 & + \\
\hline SSA_0186, comYC & SP_2051 & + & SGO_1922 & + \\
\hline SSA_0187, comYD & SP_2050 & + & SGO_1921 & + \\
\hline SSA_0188 & SP_2049 & + & SGO_1920 & + \\
\hline SSA_0189 & SP_2048 & + & SGO_1919 & + \\
\hline SSA_0190 & SP_2047 & + & SGO_1918 & + \\
\hline SSA_0191 & SP_2045 & + & SGO_1917 & + \\
\hline SSA_0192, ackA & SP_2044 & - & SGO_1916 & + \\
\hline SSA_0214, ssb2 & SP_1908 & + & SGO_1902 & + \\
\hline SSA_0215, rbsB & SP_1725 & - & SGO_1897 & - \\
\hline SSA_0216 & SP_0386 & - & SGO_1896 & - \\
\hline SSA_0217 & SP_0387 & - & SGO_1895 & - \\
\hline SSA_0218 & SP_1683 & - & SGO_1894 & + \\
\hline SSA_0310 & & & SGO_1332 & - \\
\hline SSA_0639 & SP_1808 & + & SGO_0664 & + \\
\hline SSA_0640 & & & SGO_0988 & - \\
\hline SSA_0642, pilD & SP_1808 & + & SGO_0664 & + \\
\hline SSA_0675, xseB & SP_1206 & - & SGO_0694 & + \\
\hline SSA_0676, ispA & SP_1205 & - & SGO_0695 & + \\
\hline SSA_0677, hlyA & SP_1204 & - & SGO_0696 & - \\
\hline SSA_0678, ahrC & SP_1203 & - & SGO_0697 & - \\
\hline SSA_0679, recN & SP_1202 & - & SGO_0698 & + \\
\hline SSA_0680, pphA & SP_1201 & - & SGO_0699 & + \\
\hline SSA_0715, comEA & SP_0954 & + & SGO_1602 & + \\
\hline SSA_0716, comEC & SP_0955 & + & SGO_1601 & + \\
\hline SSA_0743, argR & SP_0893 & - & SGO_1588 & - \\
\hline SSA_0749, coiA & SP_0978 & + & SGO_1575 & + \\
\hline SSA_0750 & & & & \\
\hline SSA_0824,dnaG & SP_1072 & + & SGO_1274 & - \\
\hline SSA_0825, rpoD & SP_1073 & + & SGO_1273 & - \\
\hline SSA_0826 & SP_1074 & + & SGO_1272 & - \\
\hline SSA_1183 & & & SGO_1194 & + \\
\hline SSA_1184, topA & SP_1263 & - & SGO_1197 & + \\
\hline SSA_1185, smf & SP_1266 & + & SGO_1198 & + \\
\hline SSA_1207,pta & SP_1100 & + & SGO_1219 & - \\
\hline SSA_1208 & SP_1099 & + & SGO_1220 & - \\
\hline SSA_1209,ppnK & SP_1098 & + & SGO_1221 & - \\
\hline SSA_1210 & SP_1097 & + & SGO_1222 & - \\
\hline SSA_1218, radC & SP_1088 & + & SGO_1229 & + \\
\hline SSA_1235, pyrC & SP_1167 & - & SGO_1248 & - \\
\hline SSA_1537 & SP_0782 & + & SGO_0745 & + \\
\hline
\end{tabular}


SSA_1715, serC

SSA_1716

SSA_1717, spnIM

SSA_1812

SSA_1813

SSA_1830

SSA_1831, rec $X$

SSA_1834, raiA

SSA_1835, comFC

SSA_1836, comFA

SSA_2116, cbf

SSA_2117, rmuC

SSA_2122

SSA_2156

SSA_2157, radA

SSA_2158

SSA_2159

SSA_2160, dut

SSA_2189

SSA_2192

SSA_2231

SSA_2233

SSA_2244

SSA_2245, recA

SP_1431

SP_1336

-

SP 1902

SP_1902

SP_2206

SP_2207

SP 2208

SP_1980

SP_1981

SSA_2246, $\operatorname{cin} A$

SP_0022

SP_0021

+ SGO_0169 +

SP_0200

SGO_1994 +

SP_0189

SP_1940

SP_1941

$\begin{array}{ll} & \text { SGO_1994 } \\ + & \text { SGO_2034 }\end{array}$

- SGO_2044 +

$+\quad$ SGO_2045 +

+ SGO_2046 + 
homologous to a DNA methyltransferase in S. gordonii. This gene was not found to be CSP-induced in their study, however it was found to be strongly up-regulated in this study at 5 minutes post-CSP exposure. SSA_0310 and 0640 are homologous to putative transcriptional regulators not found to be up-regulated in S. gordonii but were in fact strongly up-regulated in the microarrays in this study. Lastly, SSA_2122 is homologous to a hypothetical protein in S. gordonii which was not found to be up-regulated in their study. Overall, the 69 late response genes encode for 17 hypothetical proteins, 9 DNA modification, recombination, or repair proteins and 3 transcriptional regulators, as well as 14 of the previously discussed genes found to be essential for competence in $S$. pneumoniae.

Observation of relative expression based on abundance of transcript levels using qRT-PCR showed two waves of transcription that increased and dropped at two different stages (see Results, Section J). Whereas transcript levels of the three selected early response genes: comD, comE, and $\operatorname{com} X$, reached peak levels at 5 minutes post CSP-exposure, the selected late response genes - comYD and comEA - showed a continued increase in expression until expression of both decreased 15 minutes postCSP exposure. The results may suggest two unique stages of repression, and since transcript levels for all three of the early response genes began to drop well before those of the late response genes, it could be concluded that repression of early genes occurs simultaneously and presumably in identical fashion. Late response genes behave similarly to each other via their continued increase in transcript level until the 15 minute time point. At this point transcript levels begin to drop just as in the early response 
genes. It is important to note that although ComX has been implicated in the repression of transcription of late response genes, the decrease in transcript intensity in this study shows only that mRNA levels have fallen, either by transcriptional regulation or by their sudden instability within the cell.

As expected, comDE and $\operatorname{com} X$ were up-regulated in response to CSP. However, what is most interesting to observe are genes up-regulated that were unexpected. The results of this study show two early response genes up-regulated in response to CSP that were clustered together. SSA_0195 is a hypothetical protein whose gene lies just downstream of the comY operon and ackA gene. The fact that SSA_0195 and the other two genes were categorized under two different responses suggests that SSA_0195 has its own promoter and is transcribed separately. Its regulation could also account for the observation of SSA_0197, 0198, 0199, and 0200 appearing among the early response genes, even though their expression was minimal. Searching upstream from the start site of SSA_0195 reveals sequences similar to those seen upstream of comC and comX also suggesting that it is regulated by a similar promoter, although further investigation must be performed to confirm this. SSA_0195 shares little homology with other known proteins in closely related species, although it does share partial homology with $S$. gordonii SGO_0474 (E value = 5e-3), an abortive infection protein. The second gene also observed to respond in similar fashion to CSP was SSA_1889. This gene encodes a conserved 279-aa uncharacterized protein. Unlike what was observed in SSA_0195, the upstream sequence of SSA_1889 aligned more neatly with comC and comX, suggesting a much more strongly conserved promoter sequence. This could account for why 
expression levels in this gene appeared higher than in SSA_0195. SSA_1889 is homologous to SMU_1208c $($ E value $=6 \mathrm{e}-16)$ in S. mutans, a hypothetical protein. Just as in S. gordonii where it was observed that a unique FeS assembly protein was classified as an early response gene and shared no homology to other known upregulated genes in S. pneumoniae (108), the revelation of two genes in S. sanguinis that are strongly up-regulated early underlines the necessity of studying competence regulation in numerous streptococcal species in order to identify genes that are indispensable or nonessential for competence, as well as elucidate the competence mechanism in its entirety.

The purpose of this study was to look at gene regulation in S. sanguinis in response to competence induction, and serve as a foundation for future investigations. The amount of data collected in this study should give great insight into this regulation mechanism, and provide information for bioinformatic approaches in the future. It was also hoped that the putative $\operatorname{com} A B$ operon would be discovered based on studies showing that the ABC-type transporter was also up-regulated early in response to CSP in S. gordonii and S. pneumoniae $(84,108)$. However, no obvious transporters were found to be significantly up-regulated in this study. Interestingly, the arrays showed that several ABC-type transporters were being repressed throughout the 30-minute time course. Considering the highly unique sequence of the mature CSP peptide, and the absence of the double-Gly motif, the mechanism for CSP export across the cell wall may also be unique to S. sanguinis. Further investigations looking for homologs in other 
bacteria based on the findings in this study could prove useful in discovering the CSP transport mechanism. 
Literature Cited

1. Al-Hashimi, I., and M. J. Levine. 1989. Characterization of in vivo salivaryderived enamel pellicle. Arch. Oral Biol. 34:289.

2. Alam, S., S. R. Brailsford, R. A. Whiley, and D. Beighton. 1999. PCR-Based methods for genotyping viridans group Streptococci. J. Clin. Microbiol. 37:2772-2776.

3. Alloing, G., B. Martin, C. Granadel, and J.-P. Claverys. 1998. Development of competence in Streptococcus pneumoniae: pheromone autoinduction and control of quorum sensing by the oligopeptide permease. Mol. Microbiol. 29:7583.

4. Avery, O. T., C. M. MacLeod, and M. McCarty. 1944. Studies on the chemical nature of the substance inducing transformation of pneumococcal types: induction of transformation by a deoxyribonucleic acid fraction isolated from pneumococcus type III. J. Exp. Med. 79:137-158.

5. Bancsi, M. J., M. H. Veltrop, R. M. Bertina, and J. Thompson. 1996. Influence of monocytes and antibiotic treatment on tissue factor activity of endocardial vegetations in rabbits infected with Streptococcus sanguis. Infect. Immun. 64:448-451.

6. Berge, M., M. Moscoso, M. Prudhomme, B. Martin, and J.-P. Claverys. 2002. Uptake of transforming DNA in Gram-positive bacteria: a view from Streptococcus pneumoniae. Mol. Microbiol. 45:411-421.

7. Berlin, J. A., E. Abrutyn, B. L. Strom, J. L. Kinman, M. E. Levison, O. M. Korzeniowski, R. S. Feldman, and D. Kaye. 1995. Incidence of infective endocarditis in the Delaware Valley, 1988-1990. Am. J. Cardiol. 76:933.

8. Burnette-Curley, D., V. Wells, H. Viscount, C. L. Munro, J. C. Fenno, P. Fives-Taylor, and F. L. Macrina. 1995. FimA, a major virulence factor associated with Streptococcus parasanguis endocarditis. Infect. Immun. 63:4669-4674.

9. Campbell, E. A., S. Y. Choi, and H. R. Masure. 1998. A competence regulon in Streptococcus pneumoniae revealed by genomic analysis. Mol. Microbiol. 27:929-939.

10. Chandler, M. S., and D. A. Morrison. 1987. Competence for genetic transformation in Streptococcus pneumoniae: molecular cloning of com, a competence control locus. J. Bacteriol. 169:2005-2011.

11. Chandler, M. S., and D. A. Morrison. 1988. Identification of two proteins encoded by com, a competence control locus of Streptococcus pneumoniae. J. Bacteriol. 170:3136-3141.

12. Chen, J., and D. Morrison. 1987. Modulation of competence for genetic transformation in Streptococcus pneumoniae. J. Gen. Microbiol. 7:1959-1967.

13. Claverys, J.-P., B. Martin, and L. S. Havarstein. 2007. Competence-induced fratricide in streptococci. Mol. Microbiol. 64:1423-1433. 
14. Colman, G. 1969. Transformation of viridans-like streptococci. J. Gen. Microbiol. 57:247-255.

15. Cvitkovitch, D. G. 2001. Genetic competence and transformation in oral streptococci. Crit Rev Oral Biol Med 12:217-243.

16. Dajani, A. S., K. A. Taubert, and W. Wilson. 1997. Prevention of bacterial endocarditis: recommendations by the American Heart Association. JAMA 277:1974-1801.

17. Dubnau, D. 1999. DNA uptake in bacteria. Annu. Rev. Microbiol. 53:217-244.

18. Dubnau, D., and R. Provvedi. 2000. Internalizing DNA. Res. Microbiol. 151:475.

19. Durack, D. 1975. Experimental bacterial endocarditis. IV. Structure and evolution of very early lesions. J. Pathol. 115:81-89.

20. Durack, D. T., A. S. Lukes, and D. K. Bright. 1994. New criteria for diagnosis of infective endocarditis: utilization of specific echocardiographic findings. Am. J. Med. 96:200-209.

21. Echenique, J. R., and M.-C. Trombe. 2001. Competence repression under oxygen limitation through the two-component MicAB signal-transducing system in Streptococcus pneumoniae and involvement of the PAS domain of MicB. J. Bacteriol. 183:4599-4608.

22. Eisen, M. B., P. T. Spellman, P. O. Brown, and D. Botstein. 1998. Cluster analysis and display of genome-wide expression patterns. Proc. Natl. Acad. Sci. 95:14863-14868.

23. Facklam, R. 2002. What happened to the streptococci: overview of taxonomic and nomenclature changes. Clin. Microbiol. Rev. 15:613-630.

24. Finkel, S., and R. Kolter. 2001. DNA as a nutrient: novel role for bacterial competence gene homologs. J. Bacteriol. 183:6288-6293.

25. Fisher, S. J., A. Prakobphol, L. Kajisa, and P. A. Murray. 1987. External radiolabelling of components of pellicle on human enamel and cementum. Arch. Oral Biol. 32:509.

26. Fitzgerald, R. J., and P. H. Keyes. 1960. Demonstration of the etiologic role of streptococci in experimental caries in the hamster. J. Am. Dent. Assoc. 61:9-19.

27. Flynn, M. J., and J. Slots. 1993. Beta-hemolytic streptococci in advanced periodontitis. Oral Microbiol. Immunol. 8:295-297.

28. Forner, L., T. Larsen, M. Kilian, and P. Holmstrup. 2006. Incidence of bacteremia after chewing, tooth brushing and scaling in individuals with periodontal inflammation. J. Clin. Periodontol. 33:401-407.

29. Francioli P, R. W., Stamboulian D. 1995. Treatment of streptococcal endocarditis with a single daily dose of ceftriaxone and netilmicin for 14 days: a prospective multicenter study. Clin. Infect. Dis. 21:1406-1410.

30. Gaustad, P., and L. S. Havardstein. 1997. Competence-pheromone in Streptococcus sanguis. Identification of the competence gene comC and the competence pheromone. Adv Exp Med Biol 418:1019-21. 
31. George, E. G., and T. W. Muir. 2007. Molecular mechanisms of agr quorum sensing in virulent staphylococci. Chembiochem. 8:847-855.

32. Griffith, F. 1928. The significance of pneumococcal types. J. Hyg. 27:113-159.

33. Haanpera, M., J. Jalava, P. Huovinen, O. Meurman, and K. RantakokkoJalava. 2007. Identification of alpha-hemolytic streptococci by pyrosequencing the 16S rRNA gene and by use of VITEK 2. J. Clin. Microbiol. 45:762-770.

34. Hamada, S., M. Torii, S. Kotani, and Y. Tsuchitani. 1981. Adherence of Streptococcus sanguis clinical isolates to smooth surfaces and interactions of the isolates with Streptococcus mutans glucosyltransferase. Infect. Immun. 32:364372.

35. Havarstein, L. S., G. Coomaraswamy, and D. A. Morrison. 1995. An unmodified heptadecapeptide pheromone induces competence for genetic transformation in Streptococcus pneumoniae. Proc. Natl. Acad. Sci. 92:1114011144.

36. Havarstein LS, D. D., Nes IF. 1995. A family of bacteriocin ANC transporters carry out proteolytic processing of their substrates concomitant with export. Mol. Microbiol. 16:229-240.

37. Havarstein, L. S., P. Gaustad, I. F. Nes, and D. A. Morrison. 1996. Identification of the streptococcal competence-pheromone receptor. Mol. Microbiol. 21:863-869.

38. Havarstein, L. S., R. Hakenbeck, and P. Gaustad. 1997. Natural competence in the genus Streptococcus: evidence that streptococci can change pherotype by interspecies recombinational exchanges. J. Bacteriol. 179:6589-6594.

39. Hogevik, H., L. Olaison, R. Andersson, J. Lindberg, and K. Alestig. 1995. Epidemiologic aspects of infectice endocarditis in an urban population: a 5-year prospective study. Medicine (Baltimore) 74:324-339.

40. Horton, R. M., Z. Cai, S. N. Ho, and L. R. Pease. 1990. Gene splicing by overlap extension: tailor-made genes using the polymerase chain reaction. Biotechniques 8:528-35.

41. Hsu, S. D., J. O. Cisar, A. L. Sandberg, and M. Kilian. 1994. Adhesive properties of viridans streptoccocal species. Microb. Ecol. in Health Dis. 7:125 137.

42. Hui, F. M., and D. A. Morrison. 1991. Genetic transformation in Streptococcus pneumoniae: nucleotide sequence analysis shows $\operatorname{com} A$, a gene required for competence induction, to be a member of the bacterial ATPdependent transport protein family. J. Bacteriol. 173:372-381.

43. Hui, F. M., L. Zhou, and D. A. Morrison. 1995. Competence for genetic transformation in Streptococcus pneumoniae: organization of a regulatory locus with homology to two lactococcin A secretion genes. Gene 153:25.

44. Inamine, G. S., and D. Dubnau. 1995. ComEA, a Bacillus subtilis integral membrane protein required for genetic transformation, is needed for both DNA binding and transport. J. Bacteriol. 177:3045-3051. 
45. Isabelle Mortier-Barrière, A. d. S. J.-P. C. B. M. 1998. Competence-specific induction of recA is required for full recombination proficiency during transformation in Streptococcus pneumoniae. Mol. Microbiol. 27:159-170.

46. Ishii, S., T. Yano, and H. Hayashi. 2006. Expression and characterization of the peptidase domain of Streptococcus pneumoniae ComA, a bifunctional ATPbinding Cassette Transporter involved in quorum sensing pathway. J. Biol. Chem. 281:4726-4731.

47. Jens, K., J. Merritt, W. Shi, and F. Qi. 2005. Co-ordinated bacteriocin production and competence development: a possible mechanism for taking up DNA from neighbouring species. Mol. Microbiol. 57:392-404.

48. Jens Kreth, J. M. W. S. F. Q. 2005. Co-ordinated bacteriocin production and competence development: a possible mechanism for taking up DNA from neighbouring species. Mol. Microbiol. 57:392-404.

49. Johnsborg, O., P. E. Kristiansen, T. Blomqvist, and L. S. Havarstein. 2006. A hydrophobic patch in the competence-stimulating peptide, a pneumococcal competence pheromone, is essential for specificity and biological activity. J. Bacteriol. 188:1744-1749.

50. Kerrigan, S. W., N. S. Jakubovics, C. Keane, P. Maguire, K. Wynne, H. F. Jenkinson, and D. Cox. 2007. Role of Streptococcus gordonii surface proteins SspA/SspB and Hsa in platelet function. Infect. Immun. 75:5740-5747.

51. Kilian, M., and L. Mikkelsen. 1989. Taxonomic study of viridans streptococci: description of Streptococcus gordonii sp. nov. and emended descriptions of Streptococcus sanguis (White and Niven 1946), Streptococcus oralis (Bridge and Sneath 1982), and Streptococcus mitis (Andrewes and Horder 1906). Int. J. Syst. Bacteriol. 39:471-484.

52. Kreth, J., D. C. I. Hung, J. Merritt, J. Perry, L. Zhu, S. D. Goodman, D. G. Cvitkovitch, W. Shi, and F. Qi. 2007. The response regulator ComE in Streptococcus mutans functions both as a transcription activator of mutacin production and repressor of CSP biosynthesis. Microbiology 153:1799-1807.

53. Lacks, S., and B. Greenberg. 1976. Single-strand breakage on binding of DNA to cells in the genetic transformation of Diplococcus pneumoniae. J. Mol. Biol. 101:255.

54. Lacks, S., and M. Neuberger. 1975. Membrane location of a deoxyribonuclease implicated in the genetic transformation of Diplococcus pneumoniae. J. Bacteriol. 124:1321-1329.

55. Lancefield, R. C. 1933. A seroligical differentiation of human and other groups of hemolytic streptococci. J. Exp. Med. 57:571-595.

56. Lee, M. S., and D. A. Morrison. 1999. Identification of a new regulator in Streptococcus pneumoniae linking quorum sensing to competence for genetic transformation. J. Bacteriol. 181:5004-5016.

57. Li, J., E. J. Helmerhorst, C. W. Leone, R. F. Troxler, T. Yaskell, A. D. Haffajee, S. S. Socransky, and F. G. Oppenheim. 2004. Identification of early microbial colonizers in human dental biofilm. J. Appl. Microbiol. 97:1311-1318. 
58. Li, J. S., D. J. Sexton, D. T. Durack, T. M. Bashore, G. R. Corey, and J. Kisslo. 2000. Proposed modifications to the Duke criteria for the diagnosis of infectice endocarditis. Clin. Infect. Dis. 30:633-638.

59. Li, Y.-H., P. C. Y. Lau, J. H. Lee, R. P. Ellen, and D. G. Cvitkovitch. 2001. Natural genetic transformation of Streptococcus mutans growing in biofilms. J. Bacteriol. 183:897-908.

60. Li, Y.-H., N. Tang, M. B. Aspiras, P. C. Y. Lau, J. H. Lee, R. P. Ellen, and D. G. Cvitkovitch. 2002. A quorum-sensing signaling system essential for genetic competence in Streptococcus mutans is involved in biofilm formation. J. Bacteriol. 184:2699-2708.

61. Lockhart, P. 2000. The risk for endocarditis in dental practice. Periodontol 2000:127-135.

62. Lockhart, P., and D. Durack. 1999. Oral microflora as a cause of endocarditis and other distant site infections. Infect. Dis. Clin. North Am. 13:833-850.

63. Loesche, W. J., J. Rowan, L. H. Straffon, and P. J. Loos. 1975. Association of Streptococcus mutans with human dental decay. Infect. Immun. 11:12521260.

64. Lunsford, R. 1998. Streptococcal transformation: essential features and applications of a natural gene exchange system. Plasmid 39:10-20.

65. Lunsford, R. D., and J. London. 1996. Natural genetic transformation in Streptococcus gordonii: comX imparts spontaneous competence on strain wicky. J. Bacteriol. 178:5831-5835.

66. Méjean, V., and J. P. Claverys. 1993. DNA processing during entry in transformation of Streptococcus pneumoniae. J. Biol. Chem. 268:5594-5599.

67. Méjean, V., and J. P. Claverys. 1988. Polarity of DNA entry in transformation of Streptococcus pneumoniae. Mol. Gen. Genet. 213:444.

68. Moreillon, P., and Y.-A. Que. 2004. Infective endocarditis. The Lancet 363:139.

69. Morrison, D. A. 1997. Streptococcal competence for genetic transformation: regulation by peptide pheromones. Microb. Drug Resist. 3:27-37.

70. Morrison, D. A., and Guild, W.R. 1973. Breakage prior to entry of donor DNA in pneumococcus transformation. Biochim. Biophys. Acta. 299:545-556.

71. Murchison, H. H., J. F. Barrett, G. A. Cardineau, and R. Curtiss, 3rd. 1986. Transformation of Streptococcus mutans with chromosomal and shuttle plasmid (pYA629) DNAs. Infect. Immun. 54:273-282.

72. Murray, P. A., A. Prakobphol, T. Lee, C. I. Hoover, and S. J. Fisher. 1992. Adherence of oral streptococci to salivary glycoproteins. Infect. Immun. 60:3138.

73. Mylonakis, E., and S. B. Calderwood. 2001. Infective endocarditis in adults. N Engl J Med 345:1318-1330.

74. Nagura, J., K. Kijima, M. Kurazono, S. Takahata, T. Sugano, Y. Tanaka, Y. Hirai, K. Yamada, Y. Takayama, E. Shitara, and M. Yonezawa. 2005. Therapeutic effect of ME1036 on endocarditis experimentally induced by 
methicillin-resistant Staphylococcus aureus. Antimicrob. Agents Chemother. 49:3526-3528.

75. Netzer, R. O. M., E. Zollinger, C. Seiler, and A. Cerny. 2000. Infective endocarditis: clinical spectrum, presentation and outcome. An analysis of 212 cases 1980-1995. Heart 84:25-30.

76. Nyvad, B., and M. Kilian. 1987. Microbiology of the early colonization of human enamel and root surfaces in vivo. Eur. J. Oral Sci. 95:369-380.

77. Oggioni, M. R., C. Trappetti, A. Kadioglu, M. Cassone, F. Iannelli, S. Ricci, P. W. Andrew, and G. Pozzi. 2006. Switch from planktonic to sessile life: a major event in pneumococcal pathogenesis. Mol. Microbiol. 61:1196-1210.

78. Paik, S. 2005. Molecular analysis of virulence determinants for endocarditis in Streptococcus mutans and Streptococcus sanguinis. Virginia Commonwealth University, Richmond.

79. Paik, S., L. Senty, S. Das, J. C. Noe, C. L. Munro, and T. Kitten. 2005. Identification of virulence determinants for endocarditis in Streptococcus sanguinis by signature-tagged mutagenesis. Infect. Immun. 73:6064-6074.

80. Perry, D., and H. D. Slade. 1966. Effect of filtrates from transformable and nontransformable streptococci on the transformation of streptococci. J.

Bacteriol. 91:2216-2222.

81. Pestova, E. V., L. S. Havarstein, and D. A. Morrison. 1996. Regulation of competence for genetic transformation in Streptococcus pneumoniae by an autoinduced peptide pheromone and a two-component regulatory system. Mol. Microbiol. 21:853.

82. Pestova, E. V., and D. A. Morrison. 1998. Isolation and characterization of three Streptococcus pneumoniae transformation-specific loci by use of a lacZ reporter insertion vector. J. Bacteriol. 180:2701-2710.

83. Peterson, S., Chang Kyoo Sung, Robin Cline, Bhushan V. Desai, Erik C., Snesrud Ping Luo, Jennifer Walling,Haiying Li, Michelle Mintz, Getahun Tsegaye, Patrick C. Burr, Yu Do, Susie Ahn, Joseph Gilbert, Robert D. Fleischmann, Donald A. Morrison. 2004. Identification of competence pheromone responsive genes in Streptococcus pneumoniae by use of DNA microarrays. Mol. Microbiol. 51:1051-1070.

84. Peterson, S., R. T. Cline, H. Tettelin, V. Sharov, and D. A. Morrison. 2000. Gene expression analysis of the Streptococcus pneumoniae competence regulons by use of DNA microarrays. J. Bacteriol. 182:6192-6202.

85. Pozzi, G., L. Masala, F. Iannelli, R. Manganelli, L. S. Havarstein, L. Piccoli, D. Simon, and D. A. Morrison. 1996. Competence for genetic transformation in encapsulated strains of Streptococcus pneumoniae: two allelic variants of the peptide pheromone. J. Bacteriol. 178:6087-6090.

86. Provvedi, R., I. Chen, and D. Dubnau. 2001. NucA is required for DNA cleavage during transformation of Bacillus subtilis. Mol. Microbiol. 40:634-644. 
87. Puyet, A., B. Greenberg, and S. A. Lacks. 1990. Genetic and structural characterization of endA: A membrane-bound nuclease required for transformation of Streptococcus pneumoniae. J. Mol. Biol. 213:727.

88. Qi, F., P. Chen, and P. W. Caufield. 2001. The Group I strain of Streptococcus mutans, UA140, produces both the lantibiotic mutacin I and a nonlantibiotic bacteriocin, mutacin IV. Appl. Environ. Microbiol. 67:15-21.

89. Rimini, R., B. Jansson, G. Feger, T. C. Roberts, M. de Francesco, A. Gozzi, F. Faggioni, E. Domenici, D. M. Wallace, N. Frandsen, and A. Polissi. 2000. Global analysis of transcription kinetics during competence development in Streptococcus pneumoniae using high density DNA arrays. Mol. Microbiol. 36:1279-1292.

90. Roberts, G. J. 1999. Dentists are innocent! "Everyday" bacteremia is the real culprit: A review and assessment of the evidence that dental surgical procedures are a principal cause of bacterial endocarditis in children. Pediatr. Cardiol. 20:317-325.

91. Roberts, G. J., E. C. Jaffray, D. A. Spratt, A. Petrie, C. Greville, M. Wilson, and V. S. Lucas. 2006. Duration, prevalence and intensity of bacteraemia after dental extractions in children. Heart 92:1274-1277.

92. Romao, S., G. Memmi, M. R. Oggioni, and M.-C. Trombe. 2006. LuxS impacts on LytA-dependent autolysis and on competence in Streptococcus pneumoniae. Microbiol. 152:333-341.

93. Sconyers JR, C. J., Moriarty JD. 1973. Relationship of bacteremia to toothbrushing in patients with periodontitis. JADA 87:616-622.

94. Sherman, J. M. 1937. The streptococci. Microbiol. Mol. Biol. Rev. 1:3-97.

95. Steckelberg, J. M., and W. R. Wilson. 1993. Risk factors for infective endocarditis. Infect. Dis. Clin. North Am. 7:9-19.

96. Steinmoen, H., E. Knutsen, and L. S. Havarstein. 2002. Induction of natural competence in Streptococcus pneumoniae triggers lysis and DNA release from a subfraction of the cell population. Proc. Natl. Acad. Sci. 99:7681-7686.

97. Steinmoen, H., A. Teigen, and L. S. Havarstein. 2003. Competence-induced cells of Streptococcus pneumoniae lyse competence-deficient cells of the same strain during cocultivation. J. Bacteriol. 185:7176-7183.

98. Stock, J. B., A. J. Ninfa, and A. M. Stock. 1989. Protein phosphorylation and regulation of adaptive responses in bacteria. Microbiol. Mol. Biol. Rev. 53:450490.

99. Sung, C. K., and D. A. Morrison. 2005. Two distinct functions of ComW in stabilization and activation of the alternative sigma factor ComX in Streptococcus pneumoniae. J. Bacteriol. 187:3052-3061.

100. Takahashi, Y., E. Takashima, K. Shimazu, H. Yagishita, T. Aoba, and K. Konishi. 2006. Contribution of sialic acid-binding adhesin to pathogenesis of experimental endocarditis caused by Streptococcus gordonii DL1. Infect. Immun. 74:740-743. 
101. Tleyjeh, I. M., J. M. Steckelberg, H. S. Murad, N. S. Anavekar, H. M. K. Ghomrawi, Z. Mirzoyev, S. E. Moustafa, T. L. Hoskin, J. N. Mandrekar, W. R. Wilson, and L. M. Baddour. 2005. Temporal trends in infective endocarditis: A population-based study in Olmsted County, Minnesota. JAMA 293:3022-3028.

102. Tomasz, A. 1965. Control of the competent state in pneumococcus by a hormone-like cell product: An example for a new type of regulatory mechanism in bacteria. Nature 208:155.

103. Tomasz, A. 1966. Model for the mechanism controlling the expression of competent state in pneumococcus cultures. J. Bacteriol. 91:1050-1061.

104. Tomasz, A., and R. D. Hotchkiss. 1964. Regulation of the transformability of pneumococcal cultures by macromolecular cell products. Proc. Natl. Acad. Sci. 51:480-487.

105. Trüper, H. G., and L. de'Clari. 1997. Taxonomic note: necessary correction of specific epithets formed as substantives (nouns) "in apposition." Int. J. Syst, Bacteriol. 47:908-909.

106. Tung, S. K., L. J. Teng, M. Vaneechoutte, H. M. Chen, and T. C. Chang. 2007. Identification of species of Abiotrophia, Enterococcus, Granulicatella and Streptococcus by sequence analysis of the ribosomal 16S-23S intergenic spacer region. J Med Microbiol 56:504-513.

107. Tusher, V. G., R. Tibshirani, and G. Chu. 2001. Significance analysis of microarrays applied to the ionizing radiation response. Proc. Natl. Acad. Sci. 98:5116-5121.

108. Vickerman, M. M., S. Iobst, A. M. Jesionowski, and S. R. Gill. 2007. Genome-wide transcriptional changes in Streptococcus gordonii in response to competence signaling peptide. J. Bacteriol. 189:7799-7807.

109. Watanakunakorn, C., T. Burkert. 1993. Infective endocarditis at a large community teaching hospital, 1980 - 1990. A review of 210 episodes. Medicine (Baltimore) 72:90 - 102.

110. Ween, O., P. Gaustad, and L. S. Havarstein. 1999. Identification of DNA binding sites for ComE, a key regulator of natural competence in Streptococcus pneumoniae. Mol. Microbiol. 33:817-827.

111. Whiley, R. A., and D. Beighton. 1998. Current classification of the oral streptococci. Oral Microbiol. Immunol. 13:195-216.

112. Wilson, W., K. A. Taubert, M. Gewitz, P. B. Lockhart, L. M. Baddour, M. Levison, A. Bolger, C. H. Cabell, M. Takahashi, R. S. Baltimore, J. W. Newburger, B. L. Strom, L. Y. Tani, M. Gerber, R. O. Bonow, T. Pallasch, S. T. Shulman, A. H. Rowley, J. C. Burns, P. Ferrieri, T. Gardner, D. Goff, and D. T. Durack. 2007. Prevention of infective endocarditis: Guidelines from the American Heart Association: A guideline from the American Heart Association Rheumatic Fever, Endocarditis and Kawasaki Disease Committee, Council on Cardiovascular Disease in the Young, and the Council on Clinical Cardiology, Council on Cardiovascular Surgery and Anesthesia, and the Quality 
of Care and Outcomes Research Interdisciplinary Working Group. J Am Dent Assoc 138:739-760.

113. Xu, P., J. M. Alves, T. Kitten, A. Brown, Z. Chen, L. S. Ozaki, P. Manque, X. Ge, M. G. Serrano, D. Puiu, S. Hendricks, Y. Wang, M. D. Chaplin, D. Akan, S. Paik, D. L. Peterson, F. L. Macrina, and G. A. Buck. 2007. Genome of the opportunistic pathogen Streptococcus sanguinis. J. Bacteriol. 189:31663175.

114. Yeh, C.-Y., J.-Y. Chen, and J.-S. Chia. 2006. Glucosyltransferases of viridans group streptococci modulate Interleukin-6 and adhesion molecule expression in endothelial cells and augment monocytic cell adherence. Infect. Immun. 74:1273-1283.

115. Yoshinaga, M., K. Niwa, A. Niwa, N. Ishiwada, H. Takahashi, S. Echigo, and M. Nakazawa. 2008. Risk factors for in-hospital mortality during infective endocarditis in patients with congenital heart disease. Am. J. Cardiol. 101:114. 
VITA

\begin{abstract}
Alejandro Miguel Rodriguez was born on October 30, 1982, in Hialeah, Florida, and is an American citizen. He graduated from Dade Christian School, Miami, Florida in 2001. He received his Bachelor of Science in Biology from the University of Miami in 2005.

Publication:

Shapshak P, D.R., Nath A, Turchan J, Pandjassarame K, Rodriguez H, Duran EM, Ziegler F, Amaro E, Lewis A, Rodriguez A, Minagar A, Davis W, Seth R, Elkomy FF, Chiappelli F, Kazic T. 2006. Gene chromosomal organization and expression in cultured human neurons exposed to cocaine and HIV-1 proteins gp120 and tat: drug abuse and NeuroAIDS. Fron. Biosci. 11:1774-1793.
\end{abstract}

